\title{
Monitoring effecten zandsuppletie Leuvenumse beek 2018
}

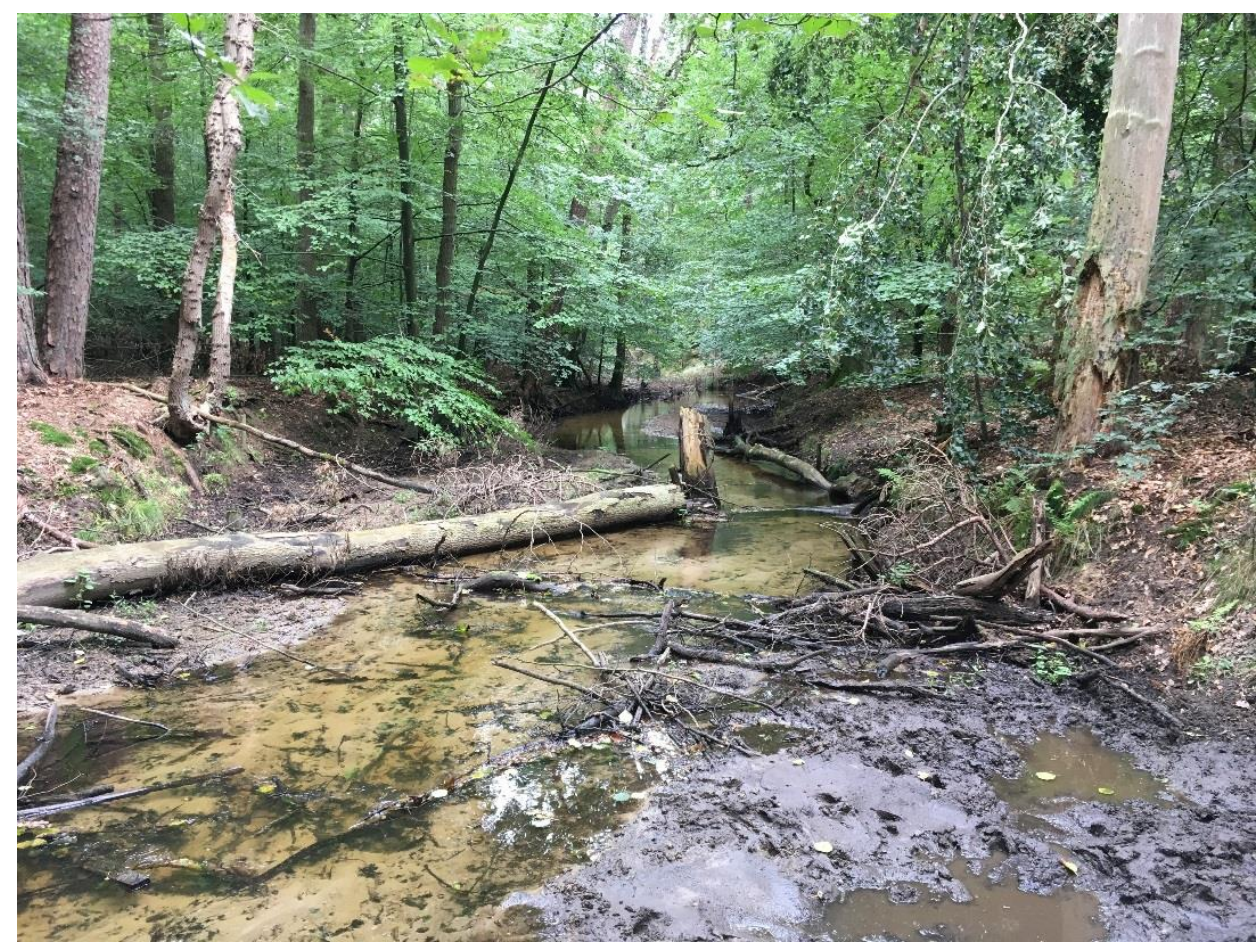

Ralf Verdonschot \& Piet Verdonschot

Notitie Zoetwatersystemen, Wageningen Environmental Research Januari 2019 


\section{Auteurs}

Ralf Verdonschot, Piet Verdonschot

\section{Opdrachtgever}

Waterschap Vallei en Veluwe; contactpersoon Maarten Veldhuis

\section{Projectgroep}

Maarten Veldhuis, Christian Huising, Peter van Beers, Marcel Timmer, Jaap Petersen (Waterschap Vallei en Veluwe); Peter Dam, Mirte Kruit, Remco van Rosmalen, Wijnand Francke (Natuurmonumenten)

\section{Referaat}

Verdonschot, R.C.M., Verdonschot P.F.M. (2019) Monitoring effecten zandsuppletie Leuvenumse beek 2018. Notitie Zoetwatersystemen, Wageningen Environmental Research, Wageningen UR, Wageningen.

\section{Trefwoorden}

beekherstel, Hierdense beek, laaglandbeek, moerasbeek, kleinschalige maatregelen, bouwen-met-natuur, macrofauna

\section{Beeldmateriaal \\ Ralf Verdonschot}

ISBN: 978-94-6343-928-2

DOI: https://doi.org/10.18174/474147

Dit onderzoek is ondersteund door het 'Innovatielab Building with Nature voor regionale wateren' (KB-24-001-007).

(c) 2019 Wageningen Environmental Research, Wageningen UR

- Overname, verveelvoudiging of openbaarmaking van deze uitgave is toegestaan mits met duidelijke bronvermelding.

- Overname, verveelvoudiging of openbaarmaking is niet toegestaan voor commerciële doeleinden en/of geldelijk gewin.

- Overname, verveelvoudiging of openbaarmaking is niet toegestaan voor die gedeelten van deze uitgave waarvan duidelijk is dat de auteursrechten liggen bij derden en/of zijn voorbehouden.

Alterra aanvaardt geen aansprakelijkheid voor eventuele schade voortvloeiend uit het gebruik van de resultaten van dit onderzoek of de toepassing van de adviezen 


\section{Inhoud}

$\begin{array}{ll}\text { Samenvatting } & 4\end{array}$

1 Inleiding en doel $\quad 5$

2 Ophoging van de beekbodem 6

2.1 Inleiding 6

2.2 Aanpak 6

2.2 Resultaten 8

3. Macrofauna in de suppletietrajecten 14

3.1 Inleiding 14

3.2 Aanpak 15

3.3 Resultaten 16

4. Macrofauna van het beekmoeras 27

4.1 Inleiding $\quad 27$

4.2 Aanpak 27

3.3 Resultaten 29

5. Discussie en conclusies 32

6. Aanbevelingen 34

$\begin{array}{ll}\text { 7. Literatuur } & 35\end{array}$

Bijlage 1: dwarsprofielen van de suppletielocaties 36

Bijlage 2: dwarsprofielen van de moerasbeek $\quad 54$

Bijlage 3: Macrofaunabemonstering moerastraject bovenstrooms Z1 57 


\section{Samenvatting}

In de Leuvenumse beek wordt vanaf 2014 het suppleren van zand als beekherstelmaatregel toegepast door Waterschap Vallei en Veluwe en Natuurmonumenten. Omdat over deze relatief nieuwe maatregel nog niet veel kennis voorhanden is, worden sindsdien de hydromorfologische en biologische ontwikkelingen gevolgd. In 2018 zijn metingen verricht aan het profiel van de beek op drie suppletielocaties en is de macrofaunasamenstelling van vijf suppletielocaties onderzocht. Beide zijn herhalingen van al eerder uitgevoerde metingen in 2014-2017, om zo de veranderingen in beeld te krijgen die in gang zijn gezet door het uitvoeren van de maatregelen. Daarnaast is ook de macrofauna van het beekmoeras bovenstrooms van het projectgebied onderzocht, dat in de loop van de jaren vernat is als gevolg van de suppleties.

In 2018 speelde het weer een belangrijke rol: hoge afvoerpieken in de winter, zware storm met als gevolg een grote aanvoer van nieuw dood hout en extreme droogte in de zomer en herfst hadden allemaal effect op het beeksysteem. Metingen aan de dwarsprofieltransecten lieten zien dat drie jaar na de laatste suppletie nog steeds zandtransport plaatsvindt. Dit zijn afvoergerelateerde sedimentpulsen (ophoging in het voorjaar, erosie in het najaar), die leiden tot een langzame verplaatsing van zand naar benedenstrooms waar op veel plekken nog steeds ophoging plaatsvindt. Een tweede aanjager van het transport zijn lokale veranderingen van de stromingspatronen in de beek door plotselinge veranderingen in de beek, bijvoorbeeld het invallen van nieuw dood hout.

De macrofaunasamenstelling in de suppletietrajecten week in 2018 af van de eerdere jaren en kenmerkte zich door een grotere variatie in taxonsamenstelling tussen de monsters. Het totaal aantal taxa was daarnaast veel hoger, maar dit werd deels veroorzaakt door het verschijnen van stilstaand-water-soorten die waarschijnlijk profiteerden van de lage afvoer. De meeste kenmerkende beektaxa handhaafden zich, al lieten een klein aantal taxa wel een teruggang zien in de frequentie van voorkomen. Daar stond tegenover dat er ook een aantal kenmerkende soorten nieuw zijn waargenomen in de trajecten in het projectgebied of zich hadden uitgebreid. Op de suppletielocaties was nog steeds de het eerst gestabiliseerde zone vlakbij de oorspronkelijke suppletieplek het rijkst aan kenmerkende taxa, terwijl de dynamische zone ten opzichte van eerdere bemonsteringen ook een duidelijke stijging in het aantal kenmerkende taxa liet zien met het verouderen van het systeem.

Ondanks de veranderde omstandigheden in het beekmoeras ten opzichte van de oorspronkelijke beekloop, met minder stroming en meer waterplanten en organisch materiaal, werd de ecologische kwaliteit als goed beoordeeld op basis van de KRW maatlat voor R5 en zelfs zeer goed op basis van de nieuwe moerasbeekmaatlat. Het beekmoeras draagt bij aan de totale biodiversiteit van het stroomgebied omdat er een aantal taxa zijn gevonden die niet op de andere locaties zijn aangetroffen.

Het onderzoek laat zien dat het projectgebied drie jaar na de suppleties nog volop in ontwikkeling is; hoe 'extremere' jaren zoals 2018 doorwerken op de langere termijn in zowel hydromorfologisch als ecologisch opzicht moet de komende jaren blijken. 


\section{$1 \quad$ Inleiding en doel}

Het beekherstel in de Hierdense beek is gericht op herstel en ontwikkeling van een zo natuurlijk mogelijk functionerend beeksysteem in het gehele beekdal van de Hierdense/Leuvenumse beek over een lengte van circa veertien kilometer (traject tussen landgoed Staverden en de monding in het Veluwemeer). Ondanks extensief beheer en de aanwezigheid van bos- en natuurgebied in en rond het beekdal van de Hierdense/Leuvenumse beek zijn er namelijk diverse knelpunten aanwezig op het gebied van de ecologie, morfologie, afvoerregime en waterkwaliteit, die het natuurlijk functioneren en daarmee de doelrealisatie in de weg staan.

Om deze knelpunten aan te pakken zijn de afgelopen jaren kleinschalige maatregelen genomen op het gebied van:

i) natuurvriendelijke inrichting van de beek en directe omgeving,

ii) natuurvriendelijk onderhoud in de beek,

iii) herstel van een natuurlijk afvoerregime (inclusief inundatiezones),

iv) het verbeteren van de ecologische kwaliteit van het gehele beekdal (o.a. antiverdrogingsmaatregelen).

Bouwen-met-natuur ('Building with nature') principes waren leidend bij de maatregelkeuze: zo veel mogelijk gebruik maken van of aansluiten op natuurlijke processen in de beek.

Eén van de toegepaste maatregelen was het gericht suppleren van zand in combinatie met het inbrengen van dood hout in het traject in het Leuvenumse bos. Het bezanden van een beek is een relatief nieuwe maatregel waarover nog niet veel kennis bestaat. Om de effecten van zandsuppletie op de ecologie en morfologie in kaart te brengen en eventueel bij te kunnen sturen wanneer dit noodzakelijk zou zijn, zijn vanaf 2014 door Wageningen Environmental Research metingen uitgevoerd om de korte-termijn-effecten in kaart te brengen (Verdonschot et al., 2016a, 2017ab). De belangrijkste inzichten van dit onderzoek zijn dat:

i) door het suppleren van zand het mogelijk is een ingesneden gekanaliseerde beek om te vormen naar een veel natuurlijkere beek waarbij de laagtes in het beekdal in verbinding komen te staan met de beekloop, wat een positieve stimulans voor de biodiversiteit in het beekdal blijkt wat betreft oevervegetatie en -fauna.

ii) enkele maanden na het suppleren van zand ontstaat er een veel gevarieerdere beekbodem, die bestaat uit een mozaïek van habitattypen en stroomsnelheden, waarvan voor dit beektype kenmerkende macrofaunasoorten profiteren.

Om meer inzicht in de verdere ontwikkeling van de suppletielocaties te krijgen, heeft Waterschap Vallei en Veluwe gevraagd de monitoring van de veranderingen in het gebied in 2018 voort te zetten. Het doel hiervan is het krijgen van een beter inzicht in:

1. Veranderingen in de beekmorfologie (dwarsprofiel) na het suppleren in de tijd. Het is het derde jaar nadat de laatste suppletie plaatsvond, het is daarom de vraag in hoeverre de gesuppleerde trajecten nog dynamiek vertonen.

2. De effecten van zandsuppletie op de beekecologie, in het bijzonder de veranderingen in de macrofaunalevensgemeenschap. In 2014 en 2016 is de samenstelling van de macrofaunalevensgemeenschappen na het suppleren vastgelegd. Al snel werden positieve effecten opgemerkt, al waren die geconcentreerd in de gestabiliseerde delen. De dynamische delen waren nog arm aan kenmerkende soorten. Met het verouderen van de zandtong is het de vraag of de verschillen tussen de delen kleiner worden.

3. De (meer)waarde van de door de maatregelen ontstane moeraszones voor de macrofauna. Juist beekbegeleidende moerassen lijken een belangrijke meerwaarde te hebben voor de beekecologie maar zijn nog zelden onderzocht (Verdonschot et al. 2016b). 


\section{Ophoging van de beekbodem}

\section{$2.1 \quad$ Inleiding}

Het suppleren van zand als beekherstelmaatregel is nog maar weinig toegepast in Nederland en daarbuiten en kennis van dit onderwerp is gebaseerd op de ervaringen met de effecten van inspoeling van sediment en het aanleggen van bodemdrempels in beken.

Gerichte monitoring naar de effecten van zandsuppletie op de beekmorfologie ontbreekt. Zo zijn er nog veel onduidelijkheden met betrekking tot het gedrag van het zand nadat de suppletie heeft plaatsgevonden. Ook is het de vraag hoe de interactie met de houtpakketten in Leuvenumse beek verloopt; aangezien deze een sterk bodemophogende werking kunnen hebben. De veranderingen in bodemhoogte zijn daarom vanaf 2014 vastgelegd, met als doel de volgende vraag te kunnen beantwoorden:

1. Hoeveel bodemophoging treedt er op benedenstrooms van de suppletielocaties en hoe verandert dit in de tijd onder invloed van afvoerpieken en de aanwezigheid van dood hout?

\subsection{Aanpak}

De veranderingen in bodemhoogte zijn voor drie suppletielocaties vastgelegd (Z1, Z2 en Z3), waarbij de eerste metingen in oktober 2014 plaatsvonden. Vervolgens is in 2015 in drie rondes zand gesuppleerd op de locaties (Tabel 2.1). Als uitgangssituatie voor het vastleggen van de effecten van zandsuppletie is oktober 2014 genomen.

Tabel 2.1: Suppletie- en meetmomenten. Per suppletie is de geschatte hoeveelheid ingebracht zand aangegeven.

\begin{tabular}{|c|c|c|c|}
\hline \multirow[b]{2}{*}{ Datum } & \multicolumn{3}{|c|}{$\begin{array}{l}\text { Schatting gesuppleerde } \\
\text { hoeveelheid zand per locatie } \\
\left(\mathrm{m}^{3}\right)\end{array}$} \\
\hline & Z1 & Z2 & Z3 \\
\hline $15 / 3 / 2014$ & & 50 & \\
\hline $26 / 6 / 2014$ & 20 & 50 & 100 \\
\hline $17 / 3 / 2015$ & 50 & 80 & 90 \\
\hline $2 / 7 / 2015$ & 50 & 40 & 50 \\
\hline $2 / 10 / 2015$ & 100 & 70 & 100 \\
\hline Totaal $\left(\mathrm{m}^{3}\right)$ & 220 & 290 & 340 \\
\hline
\end{tabular}

Benedenstrooms van de suppletielocaties zijn in 2014 meettransecten ingericht, telkens in series van drie transecten (Figuur 2.1). De eerste lag direct benedenstrooms de suppletielocatie, de tweede na het eerste benedenstroomse houtpakket en de derde voorbij het tweede houtpakket. Om het meten te vergemakkelijken werden hiervoor qua beddingvorm en substraat zo homogeen mogelijke stukken beek gekozen, zonder losse boomstammen. Gevolg hiervan was dat de onderlinge afstand tussen de trajecten kon variëren. 


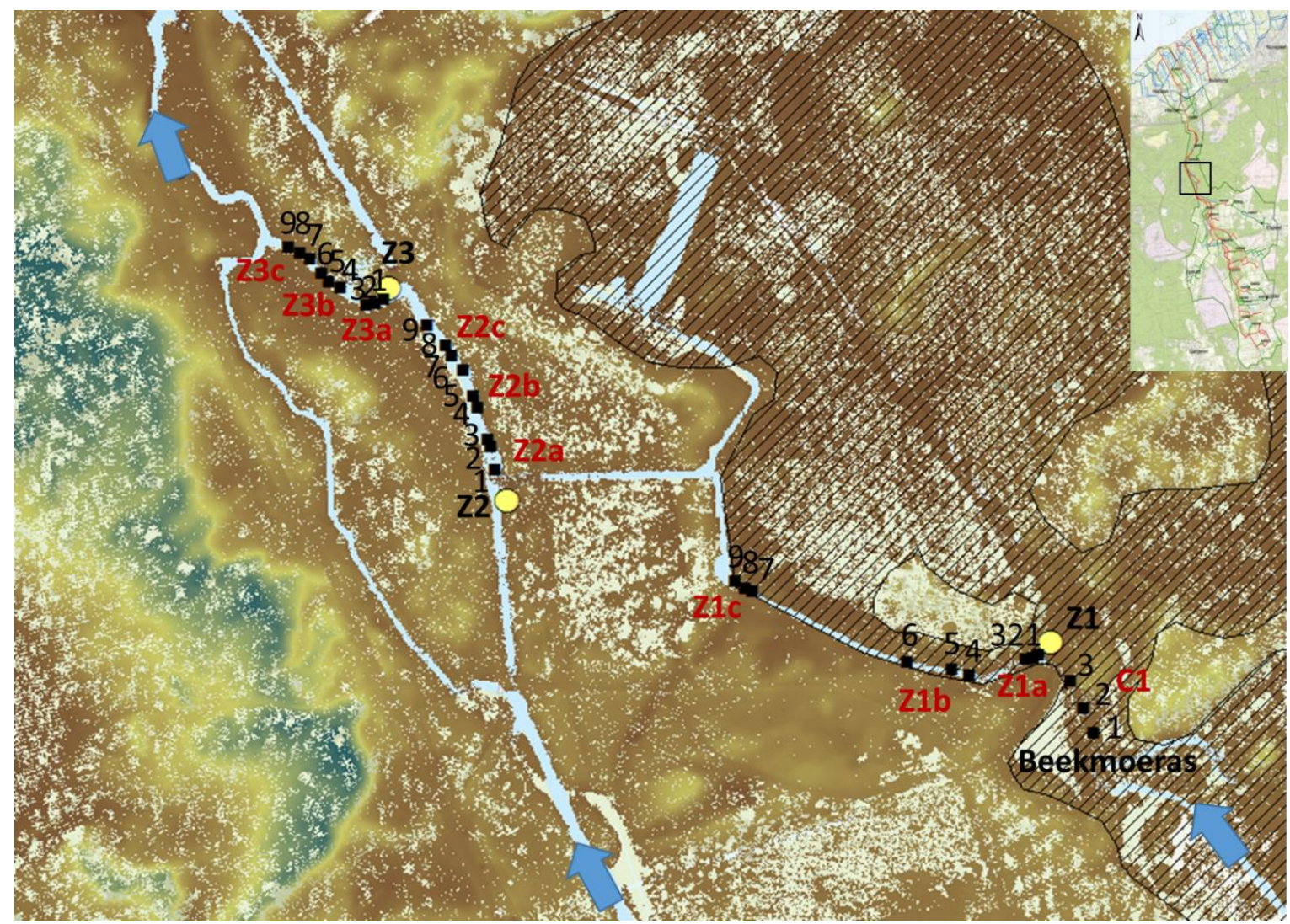

Figuur 2.1: Overzichtskaart studiegebied met de dwarsprofieltransecten waarin de bodemhoogteveranderingen zijn vastgelegd. Codes en nummers verwijzen naar de transecten (zie Bijlage 1). Gele cirkels geven suppletielocaties aan, gearceerde vlakken inundatiegebieden tijdens piekafvoeren.

Door op beide beekoevers palen te plaatsen met referentiepunten was het mogelijk een vaste horizontale lijn boven de beek te spannen. Ten opzichte van deze horizontale lijn werd telkens op iedere meter i) de hoogte tot de beekbodem of droge oever, en ii) de waterdiepte gemeten tot op $1 \mathrm{~cm}$ nauwkeurig (Figuur 2.2). Verder werden de ligging en de bodemhoogte van het diepste punt in de beek vastgelegd en ook de ligging van de oeverlijn. Omdat de beekbodem vaak niet geheel vlak was, opgebouwd was uit verschillende substraten en varieerde in stevigheid, werd gemeten met behulp van een meetstok met aan de onderzijde een schijf met een diameter van $20 \mathrm{~cm}$.

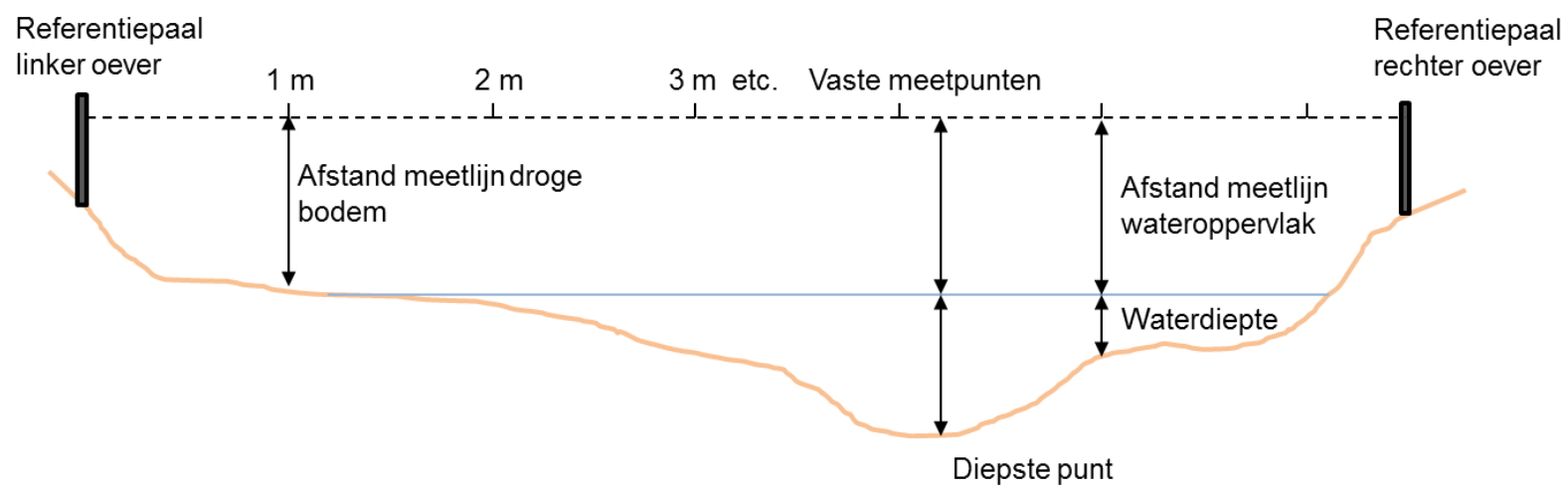

Figuur 2.2. Dwarsprofielmetingen. 
De verandering in bodemhoogte is in de tijd vastgelegd (Bijlage 1) door telkens een meting in het voorjaar en het najaar uit te voeren. In deze rapportage vergelijken we de meting van oktober 2014 met die van april en september 2016, 2017 en 2018. Gekozen is voor een voorjaars- en najaarsmeting. De voorjaarsmeting geeft de situatie na een periode van hoge afvoeren in de winter, de najaarsmeting (tijdens relatief lage afvoer) kan worden beschouwd als een uitgangssituatie voor een nieuwe periode met hoge afvoeren later in het jaar. Omdat in 2015 regelmatig opnieuw gesuppleerd werd, laten we hier de bodemhoogtemetingen uit dat jaar buiten beschouwing. We starten met het moment na de laatste suppletie om zo de ontwikkeling in de tijd te kunnen volgen zonder verstoringen van het patroon door nieuwe suppleties.

\subsection{Resultaten}

Het laatste meetjaar kenmerkte zich door weersextremen. In de winter 2017-2018 vonden twee grote afvoerpieken vlak na elkaar plaats (Figuur 2.3). Beide afvoerpieken waren bijna dubbel zo groot als de afvoerpieken in de voorgaande winters na uitvoering van de laatste suppletie. De Q50 daggemiddelde afvoer over de hydrologische jaren april 2015-maart 2018 bedroeg $0.119 \mathrm{~m}^{3} / \mathrm{s}$. Het maximale daggemiddelde in de winter 2017-2018 bedroeg 1.492 $\mathrm{m}^{3} / \mathrm{s}$, tegen winter $0.598 \mathrm{~m}^{3} / \mathrm{s}$ in 2014-2015, $0.816 \mathrm{~m}^{3} / \mathrm{s}$ in $2015-2016$ en $0.655 \mathrm{~m}^{3} / \mathrm{s}$ in 20162017. De hoge afvoeren werden gevolgd door een zware storm die op 18 januari 2018 over het gebied getrokken is, waardoor er veel nieuw dood hout in de beek terecht gekomen is. De septembermeting in 2018 is uitgevoerd tijdens een periode van extreme droogte. Het debietmeetpunt stond op dat moment droog (Figuur 2.3). De trajecten met de dwarsprofielen zijn wel watervoerend gebleven gedurende de zomer, maar hadden een relatief lage afvoer.

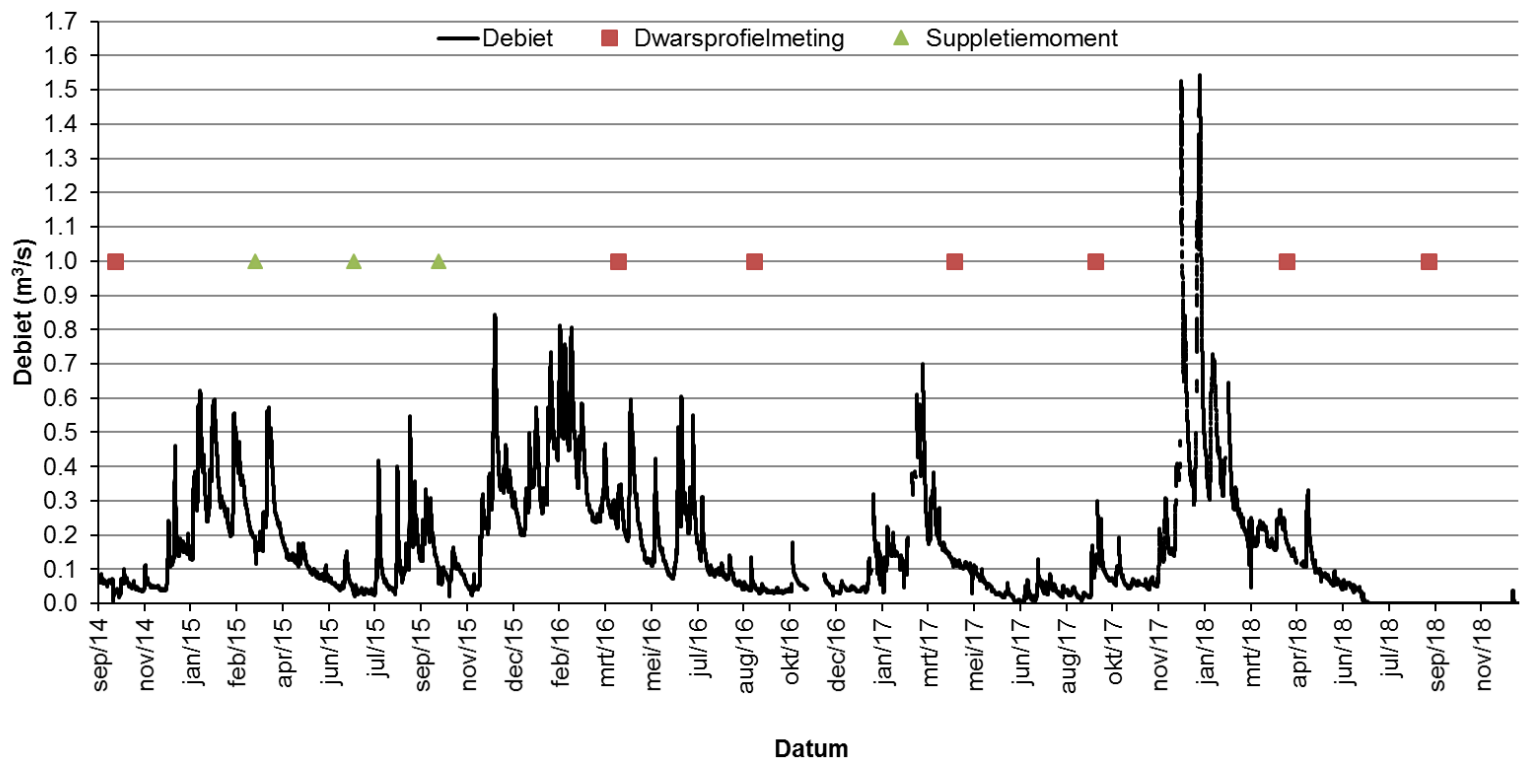

Figuur 2.3: De afvoer van de Hierdense beek in 2014-2018, gemeten op het debietmeetpunt ter hoogte van de A28, met duiding van de momenten waarop zand is gesuppleerd en wanneer de dwarsprofielmetingen zijn uitgevoerd. In de zomer van 2018 is het debietmeetpunt drooggevallen.

Drie jaar na de laatste suppletie is nog steeds een duidelijke ophoging van de beekbodem zichtbaar ten opzichte van 2014 (Figuur 2.4, Bijlage 1). Dit heeft geleid tot verondiepte profielen, zoals bijvoorbeeld op locatie Z1 (Figuur 2.5). Er vindt echter nog steeds zandtransport plaats, met plaatselijke erosie of depositie. Er zijn verschillende patronen in dit 
proces waar te nemen. In een deel van de trajecten treedt een jaarlijks terugkerend patroon op met ophoging in het voorjaar (na afvoerpieken), gevolgd door erosie (uitvlakking van de eerdere ophoging) waardoor bodemdaling wordt gemeten in het najaar (Figuur 2.4, bijvoorbeeld Z1.4b). Deze afvoergerelateerde sedimentpulsen leiden tot een langzame verplaatsing van zand naar benedenstrooms, waar nog steeds ophoging plaatsvindt. Drie jaar na de laatste suppletie treed dus nog steeds een netto verplaatsing van sediment naar benedenstrooms op, wat vooral duidelijk waarneembaar is in Z3. Dit zand lijkt nog steeds vooral afkomstig van de suppleties, bijvoorbeeld van lokale ophopingen op de oevers die in de tijd lijken af te vlakken (Bijlage 1).

Hoe dit zich in de toekomst verder ontwikkelt en of er zich uiteindelijk een evenwicht instelt moeten vervolgmetingen uitwijzen.

Een tweede patroon is dat van lokale veranderingen van de stromingspatronen in de beek door plotselinge veranderingen in de beek, met name door de natuurlijke aanvoer van nieuw dood hout maar ook door activiteiten in de beek van grote zoogdieren (zoelplekken wild zwijn, oversteekplaatsen) en recreanten (bijv. vergravingen om dammen te bouwen). Een mooi voorbeeld van een plotselinge verandering is het ontstaan van een nieuw houtpakket in transect Z1.1a na de storm van januari 2018 (Figuur 2.6). Dit leidde tot sterke lokale erosie in de rechterzijde van het profiel in transect Z1.1a en Z1.2a, wat waarschijnlijk weer een nieuwe ophoging in het benedenstroomse transect Z1.3a veroorzaakte (Figuur 2.4).

De verondieping en profielverkleining heeft een aantal voor het beekecosysteem gunstige eigenschappen, zoals behoud van relatief hoge stroomsnelheid bij lage afvoer en het snel buiten de oevers treden van de beek bij hoge afvoer, waardoor een overstromingszone ontstaat. Dit laatste treedt in de onderzochte trajecten alleen op bij Z1 en benedenstrooms hiervan (ter hoogte van het Groote water) omdat hier van nature al laagtes aanwezig waren. De veranderingen in de vegetatie door een combinatie van vernatting en meer licht door het afsterven van bomen ten opzichte van de situatie in 2014 zijn hier duidelijk zichtbaar (Figuur 2.5). In de beek zelf is hier een heterogeen mozaiek ontstaan van vegetatie (Grote waterranonkel, Sterrenkroos, Kleine watereppe) zand, grind en bladpakketten (Figuur 2.7). Hogere stroomsnelheden in combinatie met structuurvariatie door de vegetatie en dood hout heeft hier geleid tot een hogere substraatheterogeniteit. Hiervan kan de beekfauna weer profiteren (zie hoofdstuk 3).

Langs de beek groeien op locatie Z1 vooral plantensoorten gebonden aan natte tot vochtige omstandigheden en daarnaast aan voedselrijke situaties en plekken met bodemverstoring; het aantal is veel hoger dan langs de niet overstromende ingesneden trajecten (in 201749 soorten versus 13 soorten, Verdonschot \& Verdonschot 2017b). Beekbegeleidende boomsoorten als vervanging van de afgestorven droge bossoorten zijn tot nu toe schaars, zaailingen van Fladderiep en wilg zijn in 2017 aangetroffen tijdens de vegetatiekarteringen.

Ter hoogte van Z2 en Z3 zijn geen laagtes aanwezig en treden de effecten van de verondieping vooral binnen de bestaande bedding op (Figuur 2.8). 
Locatie Z1

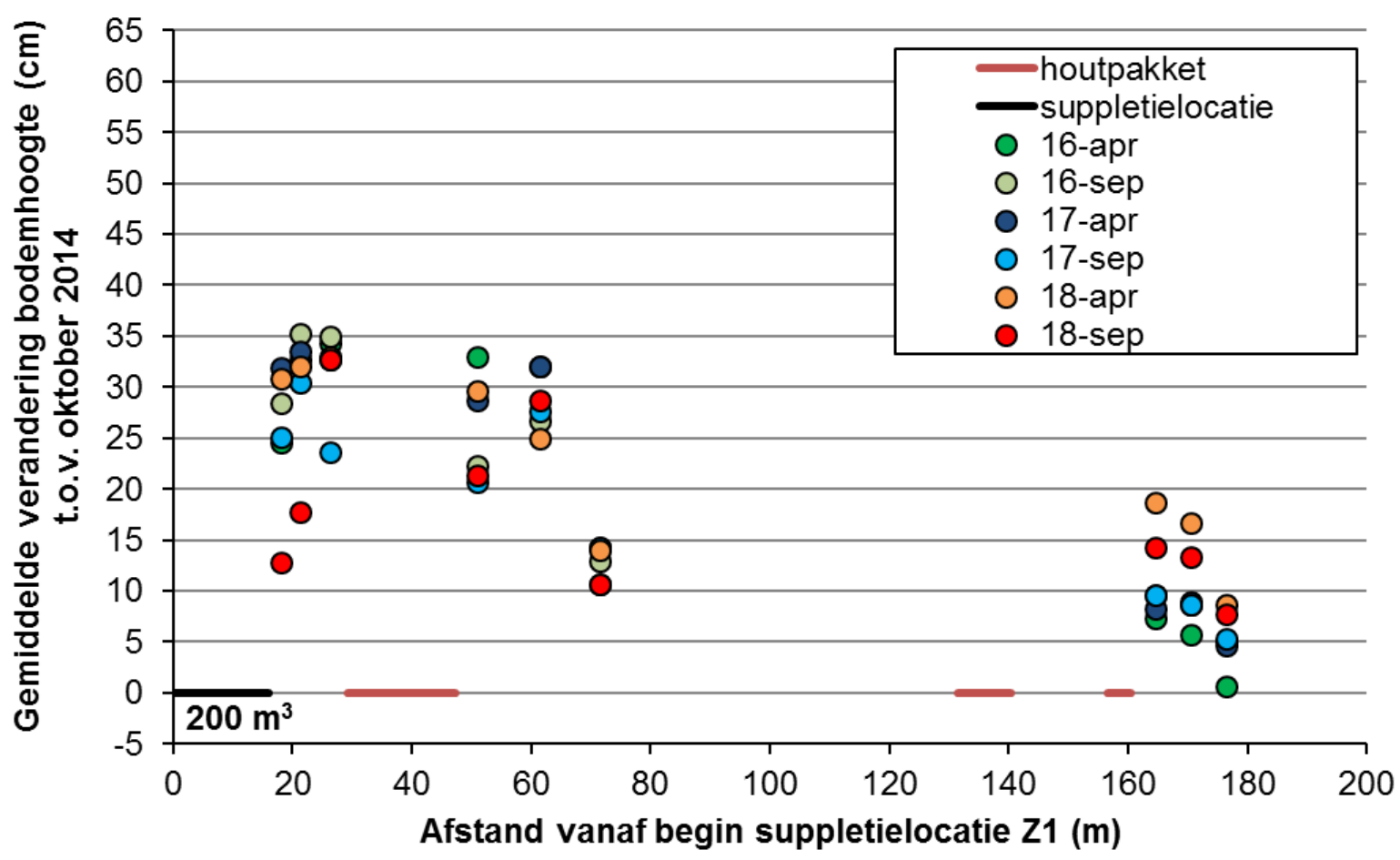

Locatie Z2+Z3

B

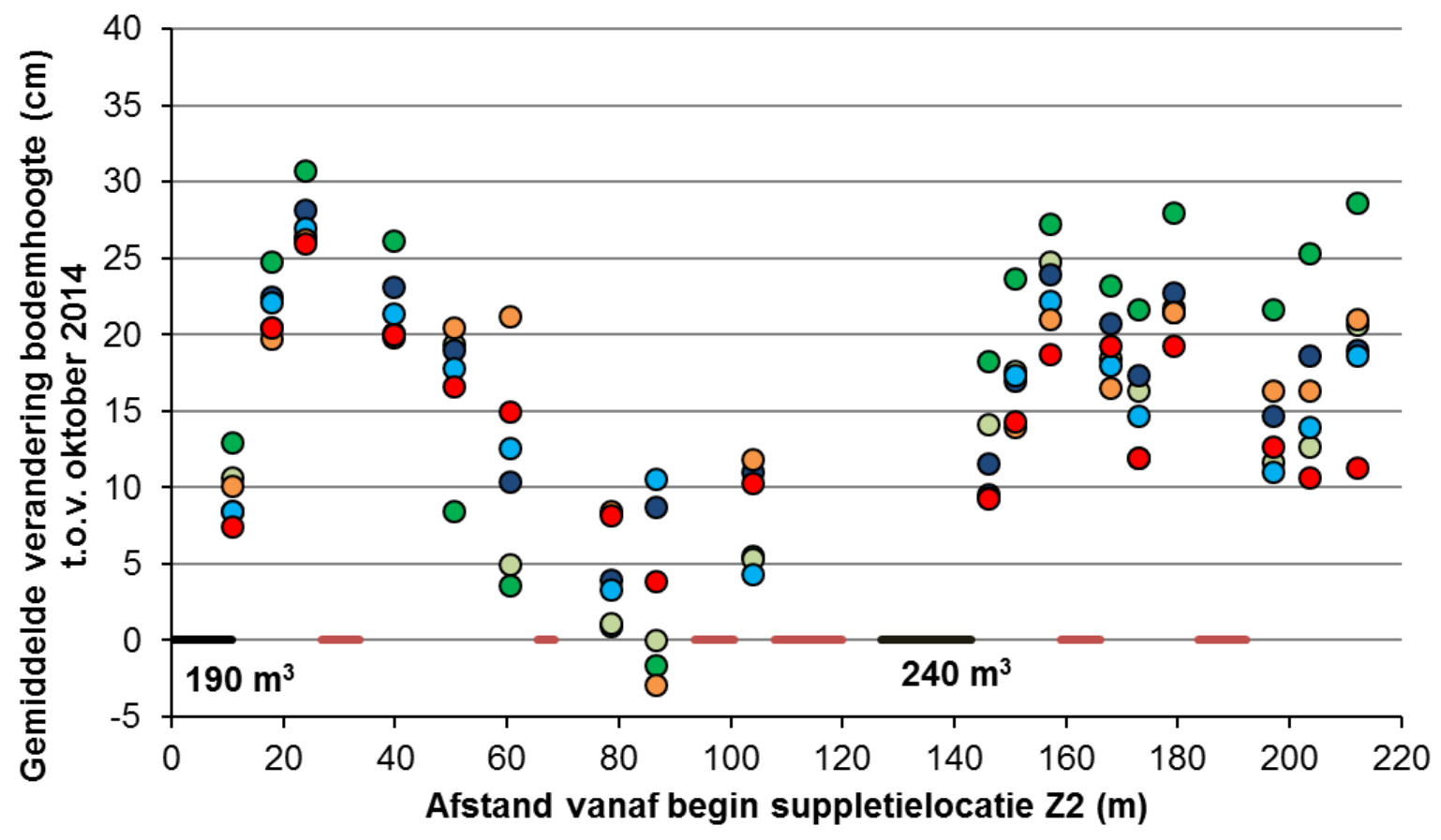

Figuur 2.4: Verandering van de gemiddelde bodemhoogte in de beektrajecten in 2018 ten opzichte van de situatie in oktober 2014 (= nullijn). De laatste suppletie heeft plaatsgevonden in oktober 2015; de getallen onder de zwarte lijnen (positie suppletielocaties in het beektraject) geven een schatting van de totale hoeveelheid ingebracht zand per locatie. Het aantal meetpunten per dwarsprofiel bedroeg gemiddeld 3,3 in Z1, 7,2 in Z2 en 4,6 in Z3. 

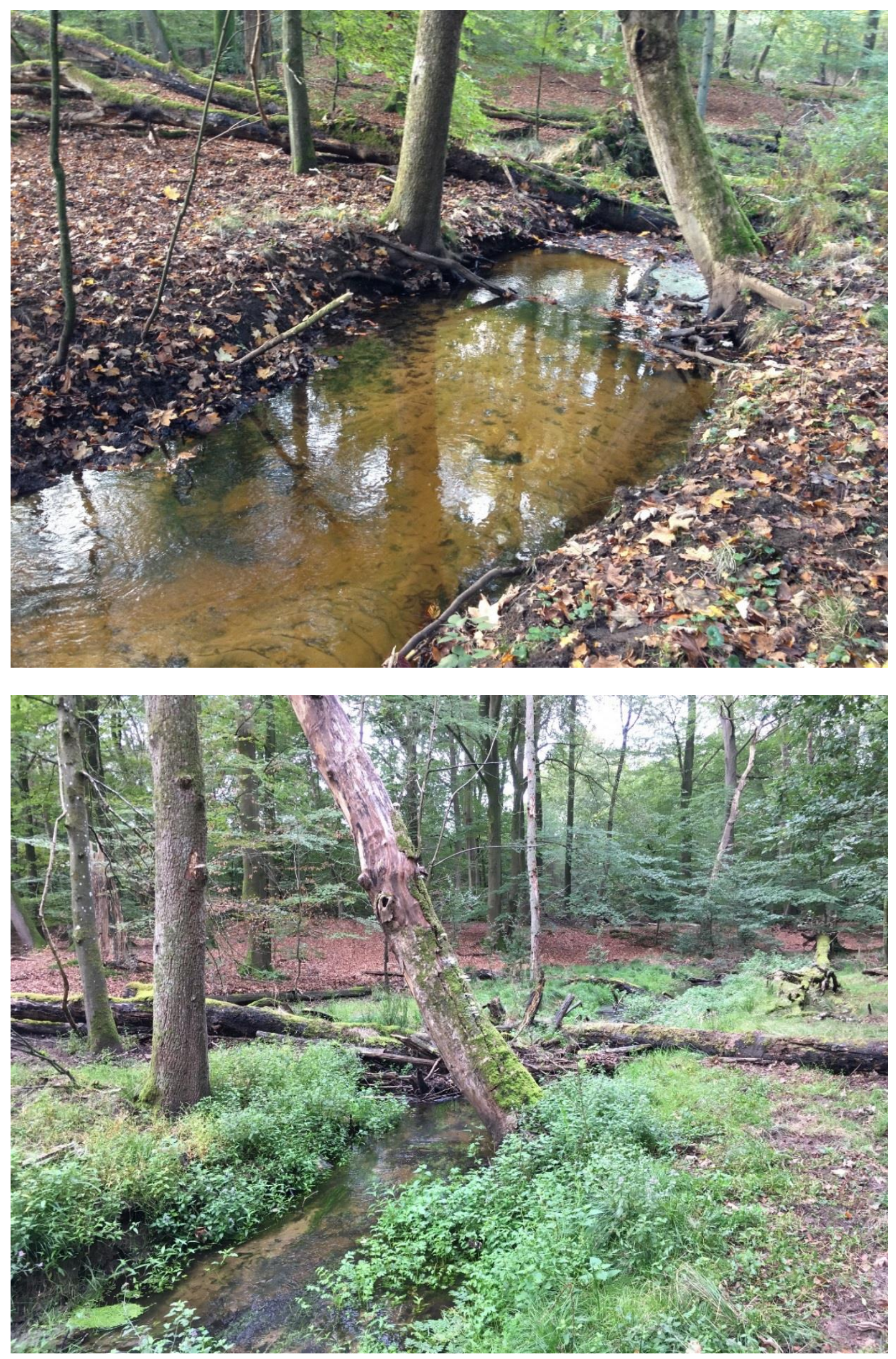

Figuur 2.5: Benedenstrooms zandsuppletielocatie Z1 in oktober 2014 (boven) en oktober 2018 (onder): verondieping door de zandsuppletie heeft geleid tot een profielverkleining en vernatting van de oeverzone. Er is een sterke toename van de vegetatie in en langs de beek te zien. 


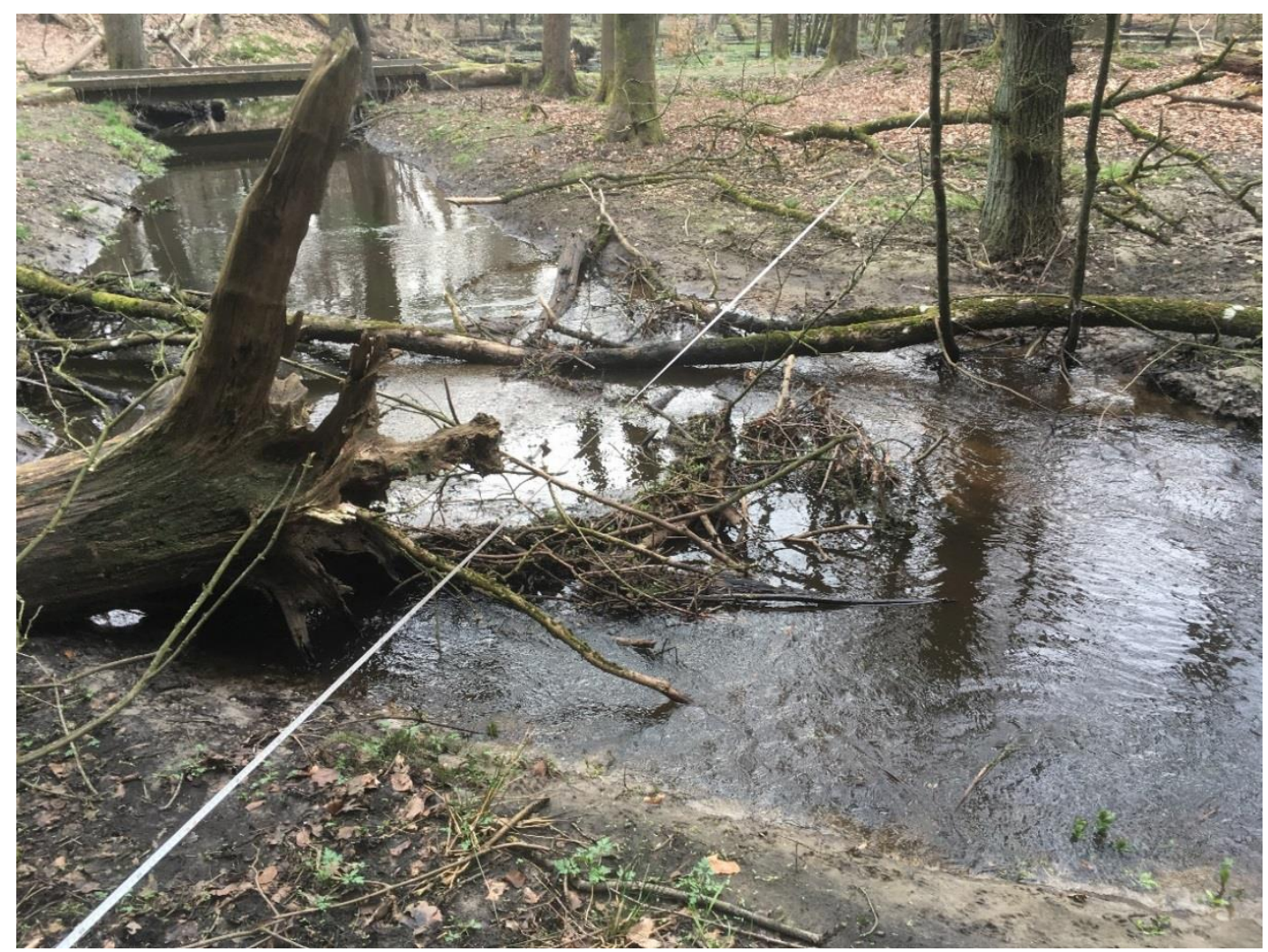

Figuur 2.6: Een op natuurlijke wijze ontstaan houtpakket in traject Z1.1a na de storm van januari 2018 heeft gezorgd voor de plotselinge profielveranderingen die in dit traject en het net benedenstrooms gelegen traject Z1.2a zijn waargenomen.

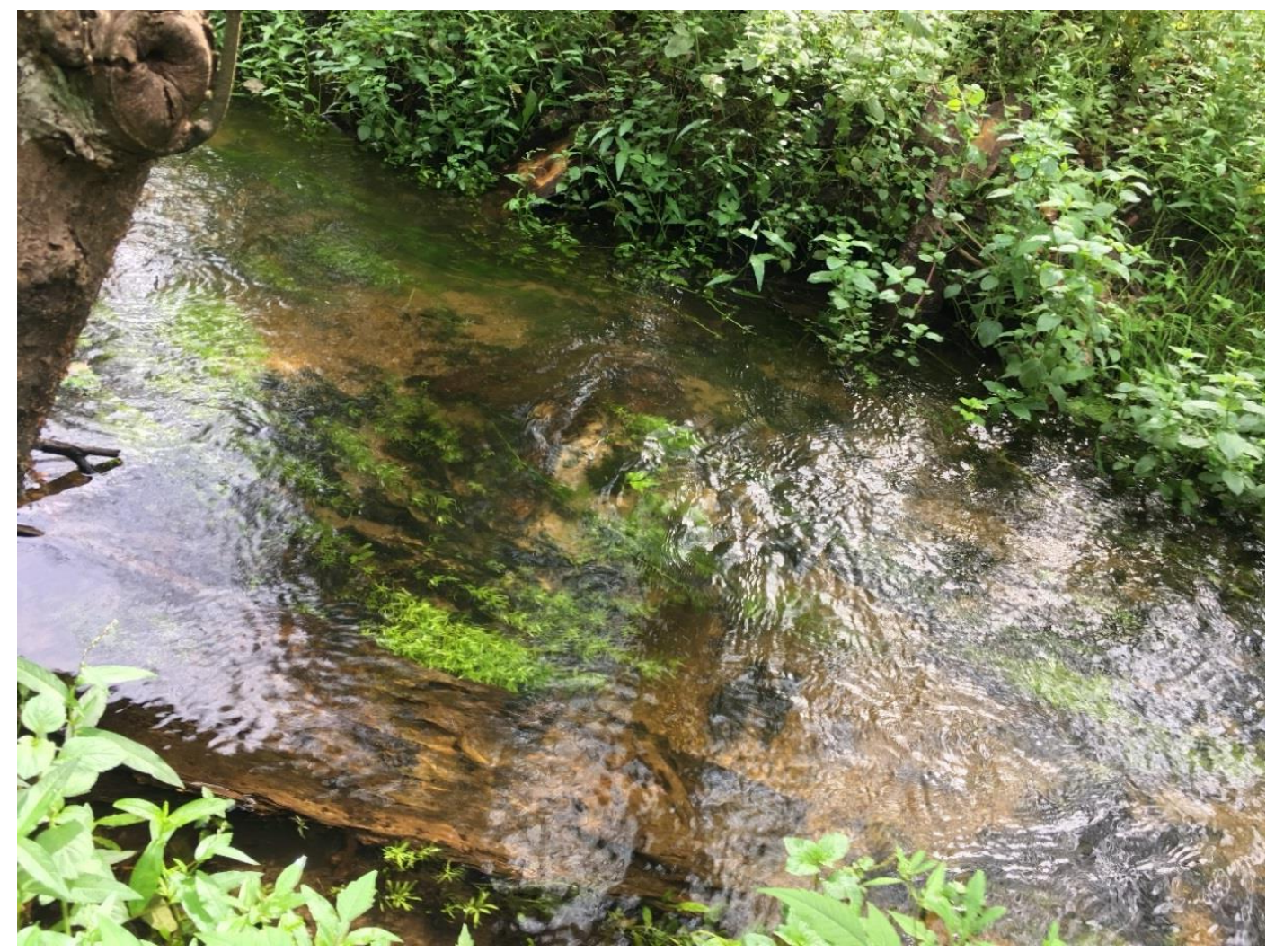

Figuur 2.7: Vegetatieontwikkeling in het verondiepte Z1 traject (september 2018), zowel in als langs de beek. 

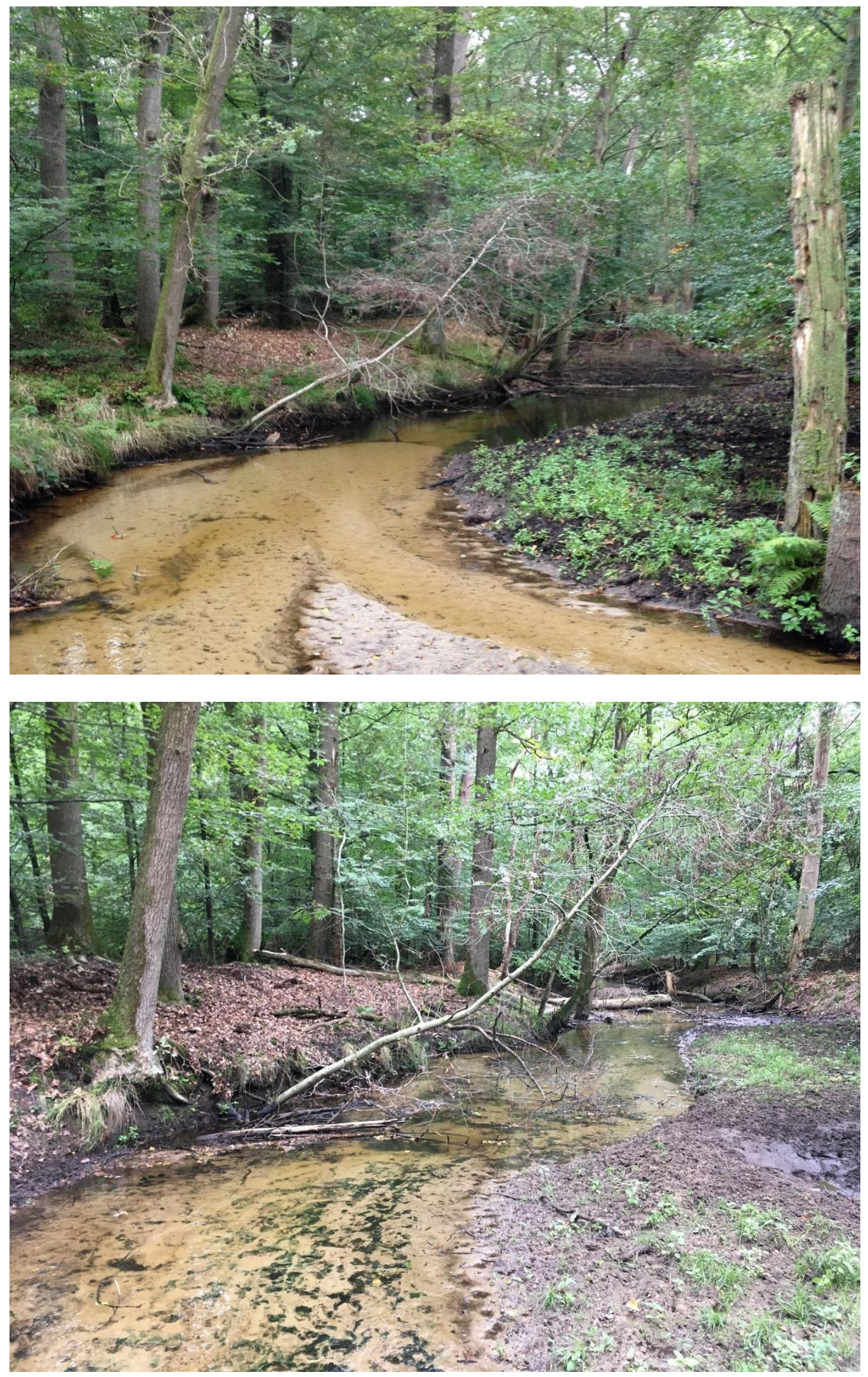

Figuur 2.8: Situatie benedenstrooms Z2 in september 2014 (boven, na eerste suppleties) en september 2018 (onder). De beek is over een grotere lengte verondiept door het ingebrachte zand. Er zijn grote veranderingen in het hoeveelheid dood hout in de beek opgetreden; enerzijds door bedekking met zand van de oorspronkelijke pakketten, anderzijds door de aanvoer van nieuw hout tijdens storm. 


\section{Macrofauna in de suppletietrajecten}

\subsection{Inleiding}

De vraag is of de ecologische kwaliteit van de gesuppleerde locaties verder verbeterd is ten opzichte van de situatie in 2014 en 2016 . Hiervoor zijn de eerdere metingen uitgevoerd op 5 suppletielocaties (Z1 t/m Z5 vanaf bovenstrooms geredeneerd) herhaald. Op iedere locatie zijn vier meetpunten bemonsterd: i) bovenstrooms suppletie (depositiezone fijn organisch materiaal), ii) plek waar zandtong is gepasseerd (mozaïek van grind-zand-blad), iii) in zandtong zelf, iv) vlak voor zandtong. Tegelijkertijd zijn ook een vijftal controlelocaties (bovenstrooms rondom Zandmolen) bemonsterd om de metingen in perspectief te kunnen plaatsen van de autonome ontwikkelingen in het gebied (Figuur 3.1).

De volgende parameters zijn opgenomen op de locaties: macrofauna (quickscan-techniek), substraatsamenstelling en bedekking, stroomsnelheid, diepte, pakking substraat. Verder zijn ook de in de monsters aangetroffen vissen genoteerd, met speciale aandacht voor de aanwezigheid van larven van de beekprik.

In 2014 en 2016 is de samenstelling van de macrofaunalevensgemeenschappen na het suppleren vastgelegd. Al snel werden positieve effecten opgemerkt, al waren die geconcentreerd in de gestabiliseerde delen. De dynamische delen waren nog arm aan kenmerkende soorten.

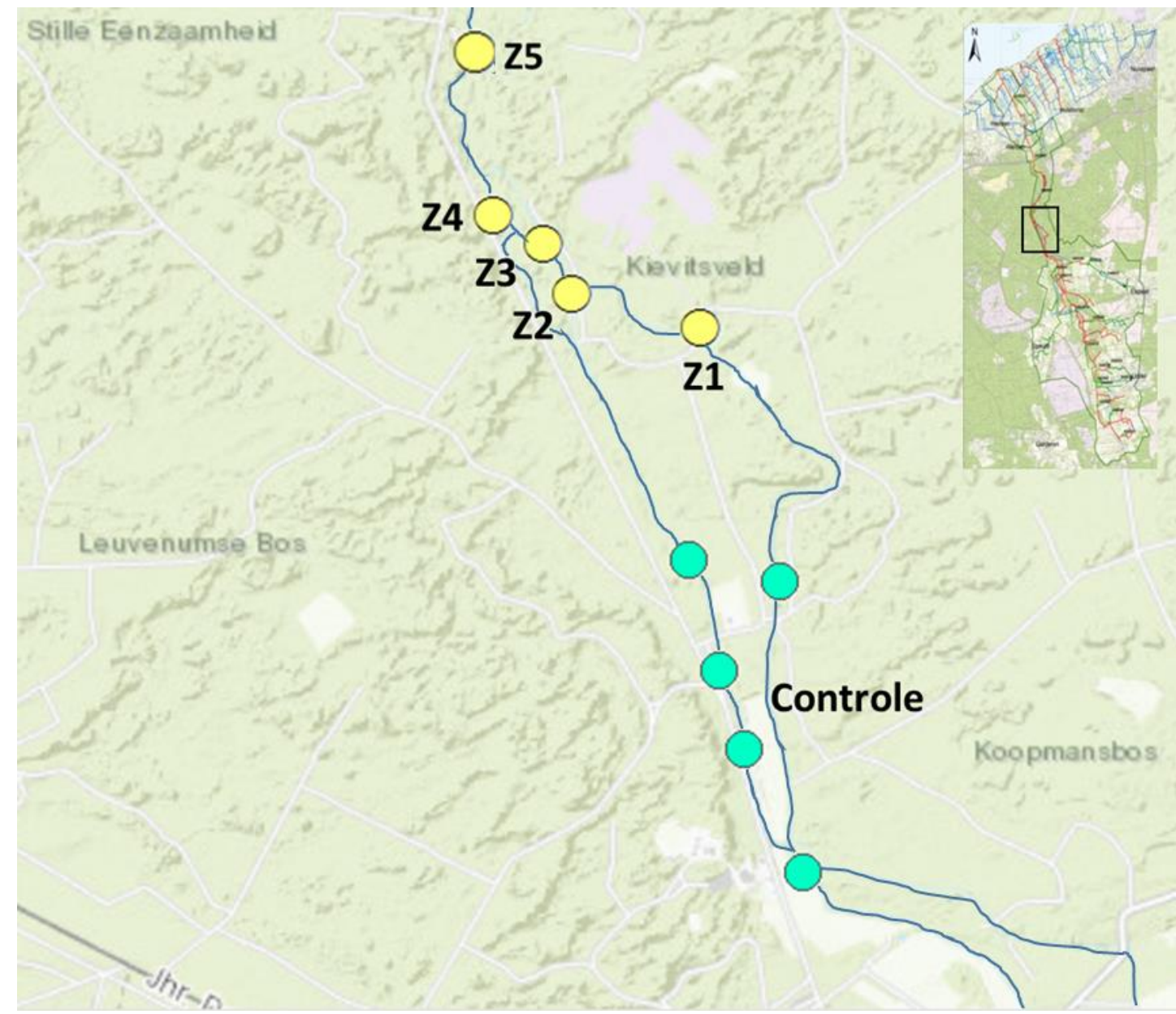

Figuur 3.1: Onderzoekslocaties effecten zandsuppletie op macrofauna (suppletielocaties Z1$Z 5$, controles verspreid over beide beektakken bovenstrooms van het projectgebied). 


\subsection{Aanpak}

De effecten op de macrofauna zijn gemeten op vijf suppletielocaties (Z1 t/m Z5) (Figuur 3.1). Om vast te stellen hoe de ecologische kwaliteit van de gesuppleerde locaties veranderd is ten opzichte van oktober 2014 en 2016 is in 2018 een vervolgbemonstering uitgevoerd. Op iedere suppletielocatie zijn vier zones bemonsterd: A) bovenstrooms van de suppletielocatie (depositiezone fijn organisch materiaal), B) de zone waar de zandtong is gepasseerd en een stabiele bodemophoging is ontstaan (mozaïek van grind-zand-blad), $\mathrm{C}$ ) in zandtong zelf (zand domineert, dynamisch omdat zand in beweging is), D) vlak voor zandtong, daar waar het zand over de oude beekbodem schuift (Figuur 3.2). Tegelijkertijd zijn er ook controlemonsters genomen bovenstrooms van het suppletietraject (random locaties tussen Koekoek en Zandmolen). Deze monsters zijn gebruikt om de door de suppletie beïnvloede situatie te kunnen vergelijken met de niet-beïnvloede situatie.

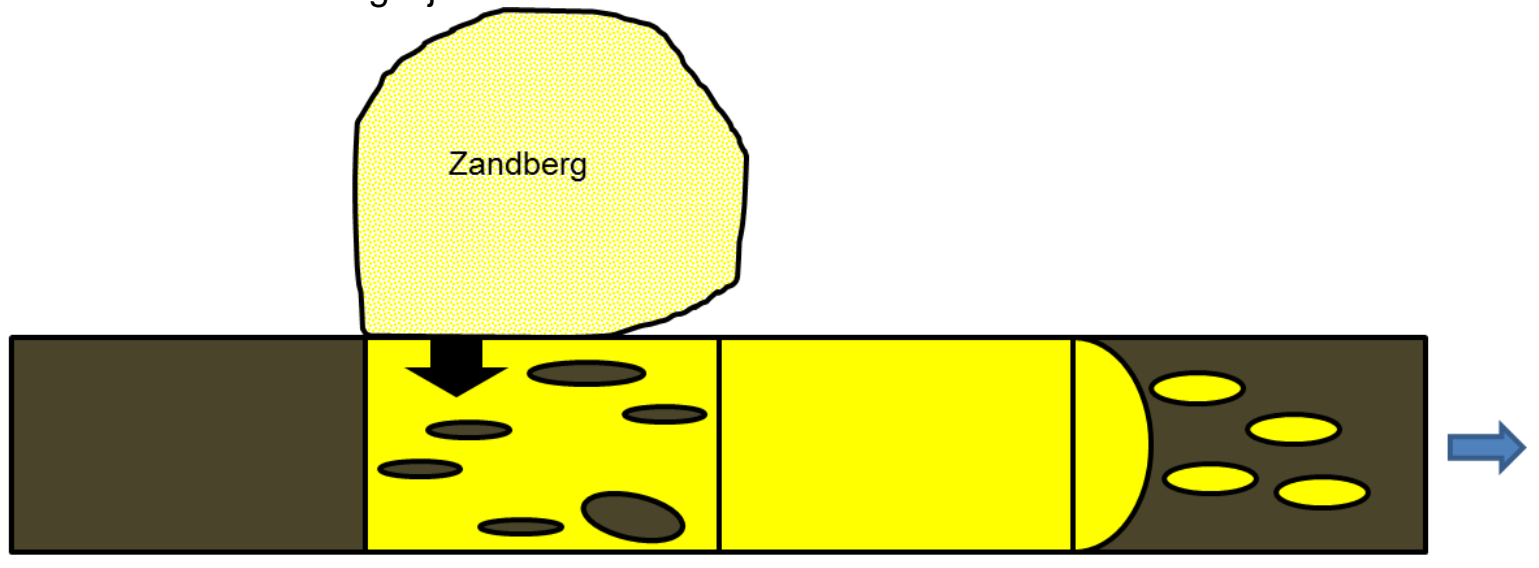

A. Bovenstroomse organische depositiezone

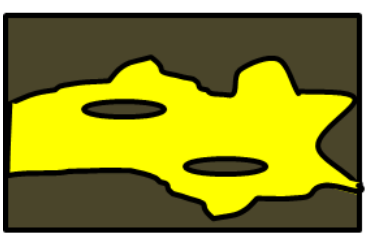

Controle (bovenstrooms)
B. Suppletie; zandfront gepasseerd
C. Suppletie; in zandfront
D. Suppletie; vlak voor zandfront

Figuur 3.2: Overzicht monsterposities op suppletielocaties met de bijbehorende substraattypen. De controlemonsters zijn genomen bovenstrooms van het traject waar zandsuppletie heeft plaatsgevonden.

ledere monsterplek werd eerst hydromorfologisch gekarakteriseerd door binnen een transect van $2 \mathrm{~m}$ een schatting te maken van het bedekkingspercentage van verschillende substraten (Tabel 3.1) en de diepte en de stroomsnelheid (op 0,4x de diepte) op het monsterpunt te meten. Ook werd vastgesteld hoe draagkrachtig het sediment was door te meten hoeveel centimeter een afgesloten PVC-buis met een diameter van $5 \mathrm{~cm}$ in het sediment gedrukt kon worden. 
Tabel 3.1. Substraten opgenomen bij de substraatschattingen.

\begin{tabular}{|l|l|l|}
\hline Type & Substraat & Toelichting \\
\hline Mineraal & Grind & Diameter $20-80 \mathrm{~mm}$ \\
\hline & Zand & Diameter $0,063-2 \mathrm{~mm}$ \\
\hline & Klei/leem & Diameter $<0,063 \mathrm{~mm}$ \\
\hline & $\begin{array}{l}\text { Stammen/takken/ } \\
\text { Wortels }\end{array}$ & Dood hout en in het water groeiende boomwortels \\
\hline & Grove detritus & $\begin{array}{l}\text { Grof organisch materiaal, zoals blad, in het eerste stadium } \\
\text { van afbraak (fragmenten duidelijk herkenbaar) }\end{array}$ \\
\hline & $\begin{array}{l}\text { Fijne detritus/ } \\
\text { Organisch slib }\end{array}$ & $\begin{array}{l}\text { Fijn organisch materiaal in een gevorderd afbraakstadium, } \\
\text { kleine deeltjes waarbij fragmenten slecht herkenbaar zijn. }\end{array}$ \\
\hline & Submerse vegetatie & Ondergedoken waterplanten \\
\hline & Emerse vegetatie & Oever-/waterplanten met delen boven water \\
\hline & Drijvende vegetatie & Planten met drijfbladeren. Kroos etc. \\
\hline & Algen & Matten/draden van op de bodem groeiende algen \\
\hline
\end{tabular}

De macrofaunabemonstering vond plaats met een Surber-sampler $(25 \times 25 \mathrm{~cm} ; 0,5 \mathrm{~mm}$ maaswijdte). Per zone werden telkens drie deelmonsters genomen, die werden gecombineerd tot één monster. Telkens werd een overgang tussen zand en grof organisch materiaal bemonsterd om de vergelijkbaarheid tussen de deelmonsters te vergroten. Om de samenstelling van de levensgemeenschap vast te stellen, werd een zogenoemde quickscantechniek gebruikt. De monsters werden uitgezocht en de dieren gedetermineerd tot op genus-niveau, met uitzondering van de zoetwaterborstelwormen (Oligochaeta), vedermuggen (Chironomidae), watermijten (Hydracarina) die tot op hoofdgroep werden gedetermineerd. De abundantie van de taxa werd in vijf klassen ingeschat (1: 1 exemplaar, 2: 2-5 exemplaren, 3: 5 -25 exemplaren, 4: 25-100 exemplaren en 5: >100 exemplaren) om een indruk te krijgen van de aanwezige dichtheden.

De analyse bestond uit het statistisch toetsen van de verschillen tussen de monsterplekken in het totale aantal taxa en het aantal taxa dat als positief kenmerkend is aangeduid voor het KRW watertype passend bij de Leuvenumse beek (R5). De KRW beoordeling gaat grotendeels uit van soorten. Omdat in de quickscan veelal tot op een hoger taxonomisch niveau is gedetermineerd, zijn alleen die indicatoren geteld die terug te herleiden waren tot het juiste taxonomische niveau. De suppletielocaties dienden als replica's en zijn geanalyseerd met repeated-measures-ANOVA's gevolgd door een Tukey post hoc procedure om de onderlinge verschillen tussen de zones te bepalen (significantie $P<0,05$ ).

\subsection{Resultaten}

De bemonstering op 8 oktober 2018 is uitgevoerd tijdens een periode van extreme droogte (zie Figuur 2.3). Alle monsterlocaties waren watervoerend tijdens de bemonstering. Van de locaties Z1-Z4 en de controles is bekend dat deze de hele zomer watervoerend zijn gebleven, maar wel een lage afvoer hadden. $Z 5$ is in de loop van juli tijdelijk drooggevallen (in ieder geval droog op 23 juli en 13 augustus 2018). Het is niet bekend wanneer Z5 weer water ging voeren. Om de watervoerendheid van het projectgebied te stimuleren is op 3 augustus 2018 de westelijke Zandmolen-tak afgedamd, waardoor al het water door de oostelijke beektak kon stromen. 


\section{$\underline{\text { Hydromorfologie }}$}

In 2018 is er nog steeds een duidelijke invloed van de suppleties op de substraatsamenstelling zichtbaar, waarbij de vooraf gedefineerde zones A-D nog steeds te onderscheiden zijn (Figuur 3.3).

Net bovenstrooms van de suppletielocaties (de organische depositiezone A.) domineert fijne detritus (afgekort fpom). De waterdiepte is hoger dan de andere zones en de stroomsnelheid lager en de bodem is slap (Figuur 3.4). Op de plek waar het zandfront als eerste passeerde, oftewel op de plek ter hoogte van en net benedenstrooms van de oorspronkelijke zandberg (zone B), is een zeer heterogene bedding ontstaan met een hoge substraatdiversiteit. Dit is deels het gevolg van de samenstelling van het ingebrachte materiaal (bron van grind) en verder ontstaan door aanvoer van blad en hout dat door de grotere stromingsvariatie in de gesuppleerde trajecten een heterogeen patroon vormt. Dit is de situatie waarnaar gestreefd wordt voor de totale beek. In dit mozaiek valt ook een toename van vegetatie in de beek op in de tijd (waarschijnlijk door verbeterde lichtomstandigheden door afsterven bomen als gevolg van de vernatting van de oeverzones) en het relatief hoge aandeel grind. De vegetatie bestaat onder andere uit grote waterranonkel (Ranunculus peltatus), sterrenkroos (Callitriche sp.) en Kleine watereppe (Berula erecta). De stroomsnelheid is er significant hoger dan op andere locaties en de bodem is stevig (Figuur 3.4). In het zandfront, waar nog steeds een hoge dynamiek is (zone C), domineert zand. Wel is het aandeel grof organisch materiaal (afgekort cpom) in 2018 licht toegenomen. De controle en het traject vlak voor het zandfront (zone D) zijn deels vergelijkbaar qua substraatbedekking, stroomsnelheid en diepte, met als verschil dat er in zone $D$ meer ophopingen van fijn organisch materiaal aanwezig zijn en daarmee de bodem ook slapper is in vergelijking met de controle. 

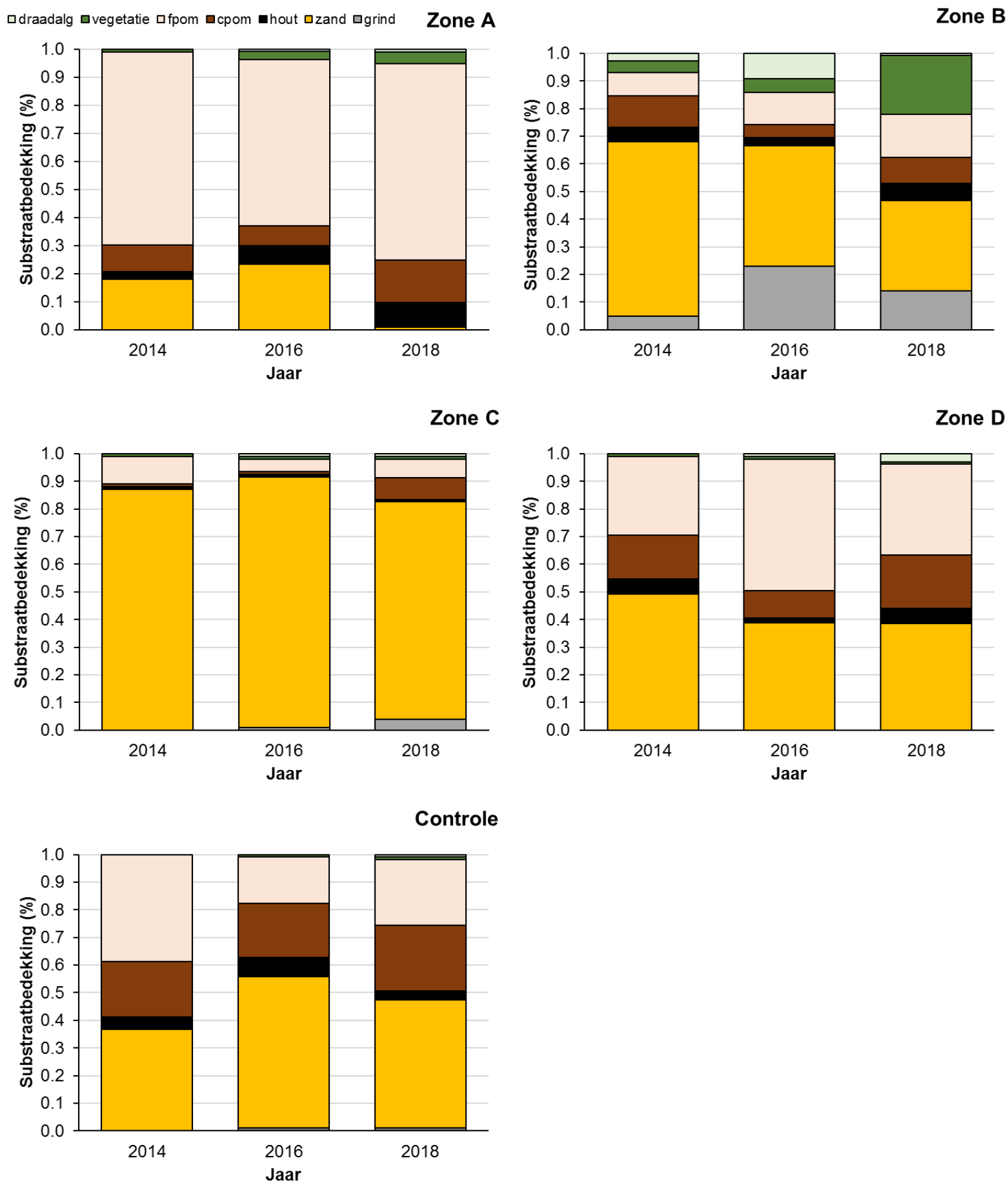

Figuur 3.3: Visuele inschatting van de substraatbedekking (gemiddelde waarde 5 locaties) in de verschillende bemonsteringsjaren. Op iedere suppletielocatie zijn vier zones bemonsterd: A) bovenstrooms suppletie (depositiezone fijn organisch materiaal), B) de zone waar de zandtong is gepasseerd en een stabiele bodemophoging is ontstaan (mozaïek van grindzand-blad), C) in zandtong zelf (zand domineert, dynamisch omdat zand in beweging is), D) vlak voor zandtong, daar waar het zand op de oude beekbodem schuift. Afkortingen: cpom= grof organisch materiaal, fpom: fijn organisch materiaal. 


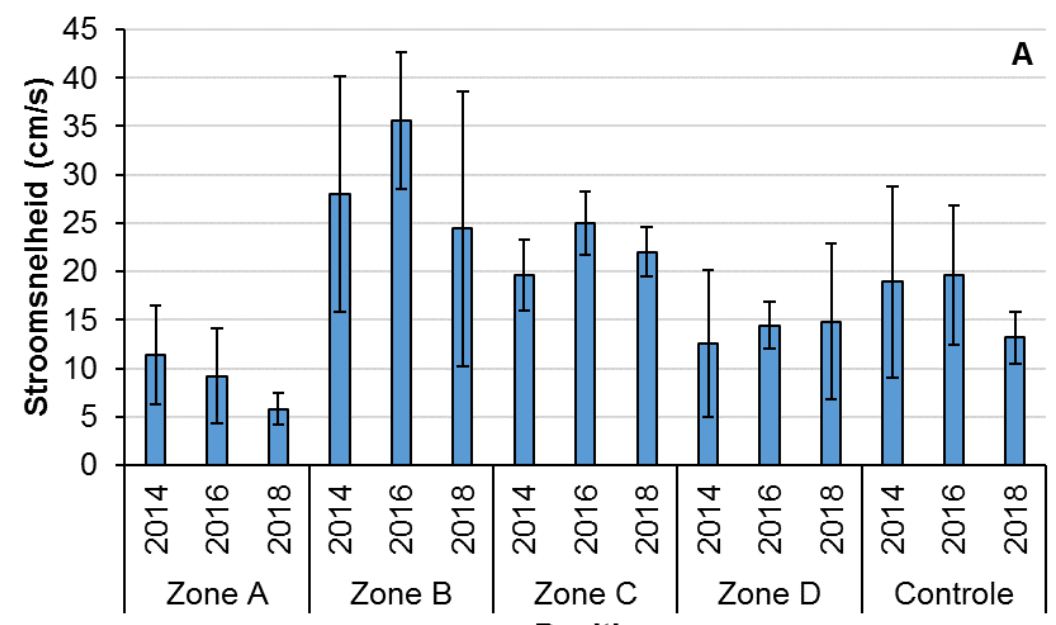

Positie

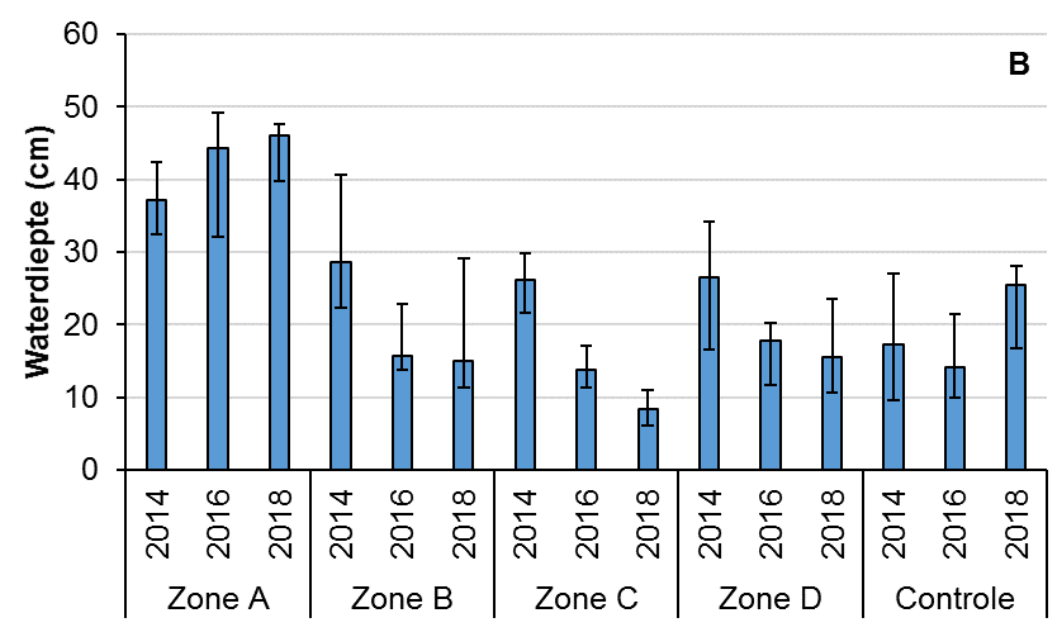

Positie

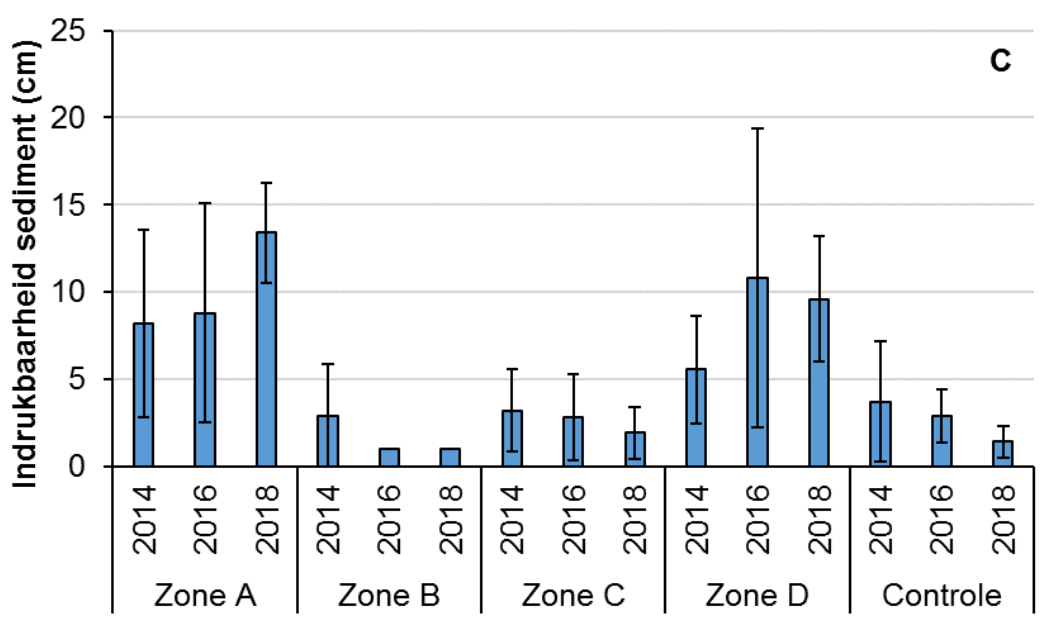

Positie

Figuur 3.5: Stroomsnelheid, waterdiepte en pakking van het sediment (gemiddelde waarde 5 locaties \pm 1 standaarddeviatie) in de verschillende bemonsteringsjaren. Op iedere suppletielocatie zijn vier zones bemonsterd: A) bovenstrooms suppletie (depositiezone fijn organisch materiaal), B) de zone waar de zandtong is gepasseerd en een stabiele bodemophoging is ontstaan (mozaïek van grind-zand-blad), C) in zandtong zelf (zand domineert, dynamisch omdat zand in beweging is), D) vlak voor zandtong, daar waar het zand op de oude beekbodem schuift. 


\section{$\underline{\text { Macrofauna }}$}

In 2018 zijn in de monsters 51 taxa aangetroffen, meer dan in 2014 en 2016 toen respectievelijk 33 en 35 taxa werden gevonden (Bijlage 3). Alle taxa uit 2016 zijn opnieuw gevonden, ten opzichte van 2014 geldt dat alleen de taxa Dryops (waterkever), Trocheta (bloedzuiger), Dugesia (platworm) en Physa (slak) niet zijn aangetroffen. De nieuw waargenomen taxa in 2018 zijn vooral kokerjuffers, haften, waterkevers en slakken. Het betreft voor een aanzienlijk deel soorten die ook in stilstaand water worden gevonden, zoals de haften Cloeon en Caenis, de slakken Planorbarius, Hippeutis, Lymnaeidae, Gyraulus, Bathyomphalus en de kokerjuffer Oecetis. Van de andere nieuw aangetroffen kokerjuffers in 2018 zijn er twee kenmerkend voor watertype R5: Bereidae: Beraeodes en

Sericostomatidae: Notidobia. Beraeodes werd alleen in het controletraject gevonden, Notidobia in zowel de controle als gesuppleerde trajecten Z1 en Z2.

Verder werden nog een aantal niet eerder gevonden kevers aangetroffen van de familie Dytiscidae: Hydroporus, Ilybius en Stictotarsus duodecimpustulatus. Deze laatste soort werd eenmaal gevonden op locatie Z5 en is kenmerkend voor watertype R5. Het is een vrij zeldzame soort van stromend water of de golfslagzone van stilstaand water met een zand of grindbodem. De bijzondere waterwants Sigara hellensii werd in 2018 op maar liefst 3 suppletielocaties gevonden, in 2016 kwam de soort op 1 locatie voor. Geen enkele van de in 2018 nieuw waargenomen taxa zijn nieuw voor het stroomgebied van de Hierdense beek, alle soorten zijn in het verleden al eens aangetroffen.

Tabel 3.2: Resultaten Repeated Measures(RM)-ANOVA macrofaunamonsters, waarbij getest is of er statistisch aantoonbare verschillen $(P<0,05)$ zijn in het aantal taxa waren tussen de meetjaren en de positie ( $A-D$, zie Figuur 3.6) ten opzichte van de suppletie. Meetjaar $x$ positie geeft de interactie tussen beide variabelen weer, oftewel of tussen de jaren er een verschil in het gevonden patroon voor de posities optreedt.

\begin{tabular}{lllll}
\hline Variabele & Factor & df & F & P \\
\hline Totale taxonrijkdom & Meetjaar & $1 ; 19$ & 39,23 & $<0,001$ \\
& Positie & $4 ; 19$ & 4,14 & 0,001 \\
& Meetjaar x Positie & $4 ; 19$ & 10,06 & $<0,001$ \\
Aantal kenmerkende taxa watertype R5 & Meetjaar & $1 ; 19$ & 22,13 & $<0,001$ \\
& Positie & $4 ; 19$ & 7,05 & $<0,001$ \\
& Meetjaar x Positie & $4 ; 19$ & 3,19 & 0,007 \\
\hline
\end{tabular}

De totale taxonrijkdom en het aantal kenmerkende taxa verschilt tussen de jaren en tussen de zones, maar een interactie tussen jaar en positie geeft aan dat de patronen in aantallen taxa tussen de jaren verschillen (Tabel 3.2). Om deze variatie beter in beeld te krijgen is er een vergelijking tussen de verschillende zandsuppletie-zones en de controle per jaar gemaakt (Figuur 3.6). Voor de totale taxonrijkdom zijn er in 2014 significante verschillen tussen de zones waargenomen, met de dynamische zone $\mathrm{C}$ die een lagere rijkdom ten opzichte van de andere zones heeft. Dit verschil is in de jaren erna verdwenen. Voor het aantal kenmerkende taxa geldt dat in 2014 de dynamische zone een significant lager aantal kenmerkende taxa herbergt, terwijl in 2016 er geen verschillen aanwezig zijn in kenmerkende taxa tussen de zones. In 2018 is de situatie plotseling anders: de controle herbergt het grootste aantal kenmerkende taxa, terwijl het aantal kenmerkende taxa in de zones $A, C$ en $D$ en lager ligt. De herstelde zone $B$ neemt een tussenpositie in. Ondanks dat zone $C$ in eerste instantie relatief arm is, neemt het aantal taxa toe in de loop van de tijd tot een niveau dat voor de totale taxonrijkdom vergelijkbaar is met de andere meetlocaties. 
Wanneer de verschillende jaren vergeleken worden, dan wijkt 2018 duidelijk af van 2014 en 2016 (Figuur 3.7). De controle en de dynamische zone C zijn beide rijker aan taxa in 2018 en voor het totaal aantal taxa geldt dit ook voor zone B.
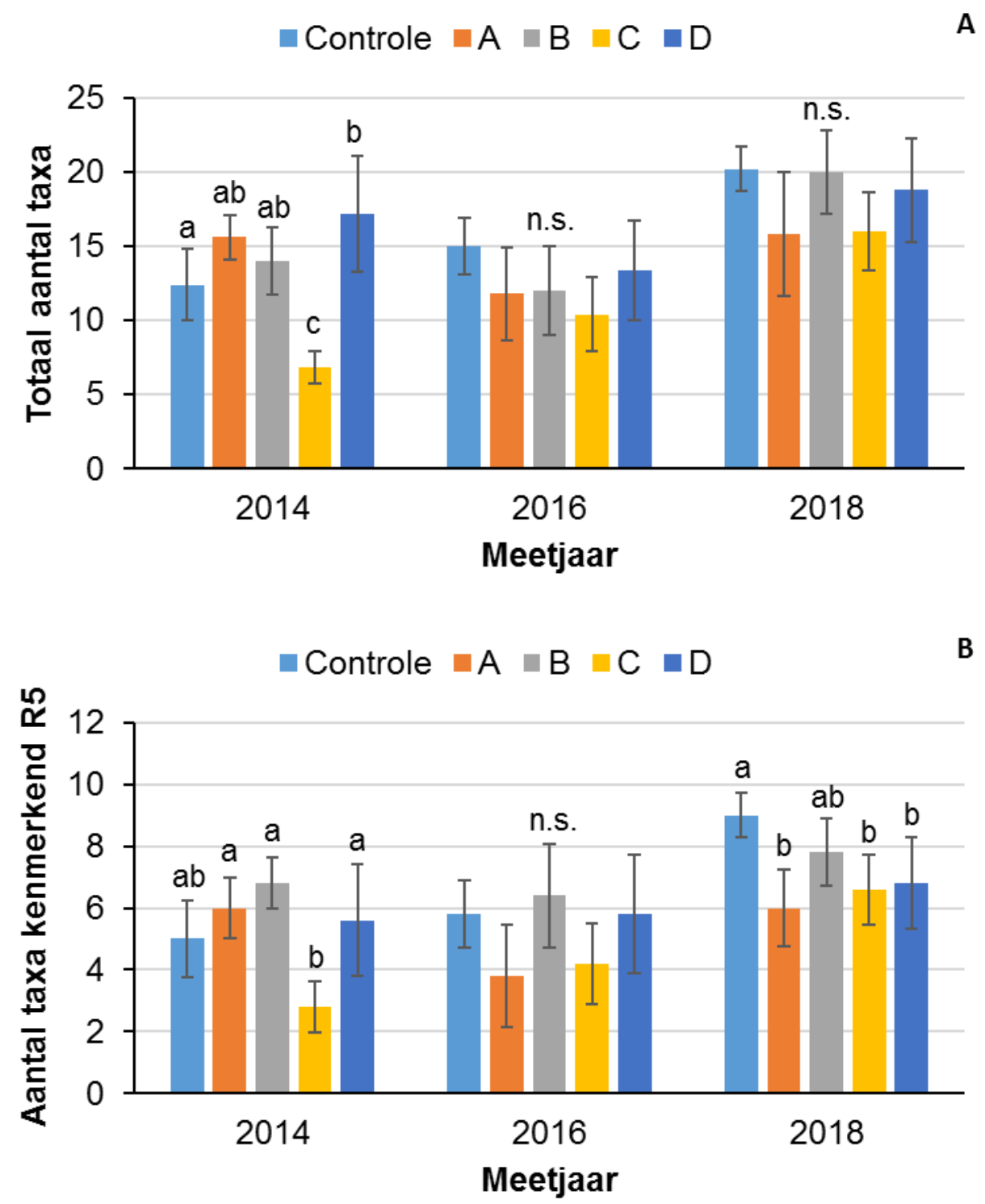

Figuur 3.6: Vergelijking taxonrijkdom op de verschillende monsterposities binnen een meetjaar. Het gemiddelde ( \pm 1 standaarddeviatie) voor de totale taxonrijkdom $(A)$ en het aantal voor watertype $R 5$ kenmerkende taxa $(B)$ op de suppletielocaties $(n=5)$ is gegeven. Letters geven de significante verschillen tussen de monsterposities weer, n.s.: niet significant (One-way ANOVA's met Tukey post hoc tests). 

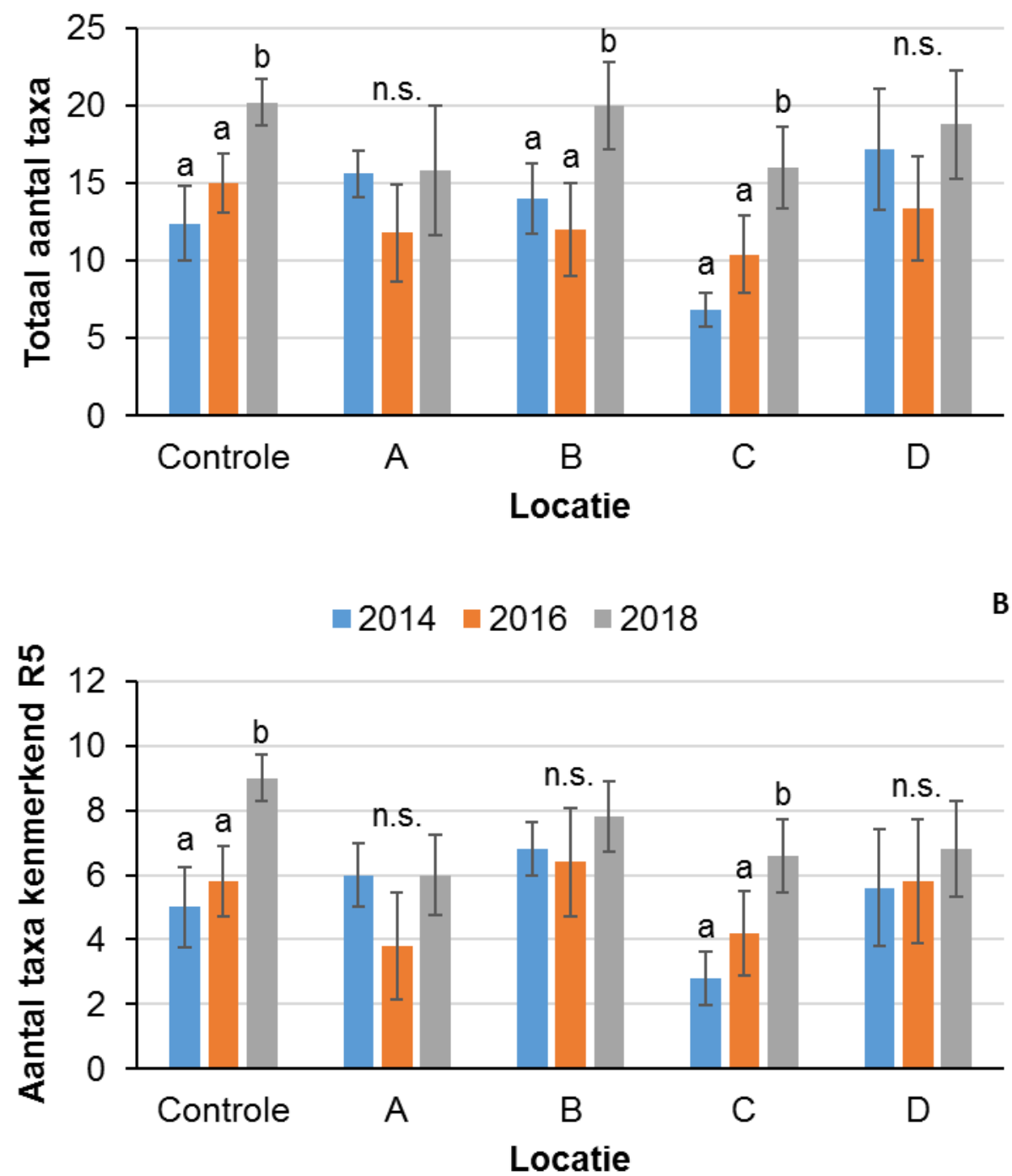

Figuur 3.7: Vergelijking taxonrijkdom op de verschillende monsterposities tussen de meetjaren. Het gemiddelde ( \pm 1 standaarddeviatie) voor de totale taxonrijkdom $(A)$ en het aantal voor watertype $R 5$ kenmerkende taxa $(B)$ op de suppletielocaties $(n=5)$ is gegeven. Letters geven de significante verschillen tussen de jaren weer, n.s.: niet significant (One-way ANOVA's met Tukey post hoc tests). 


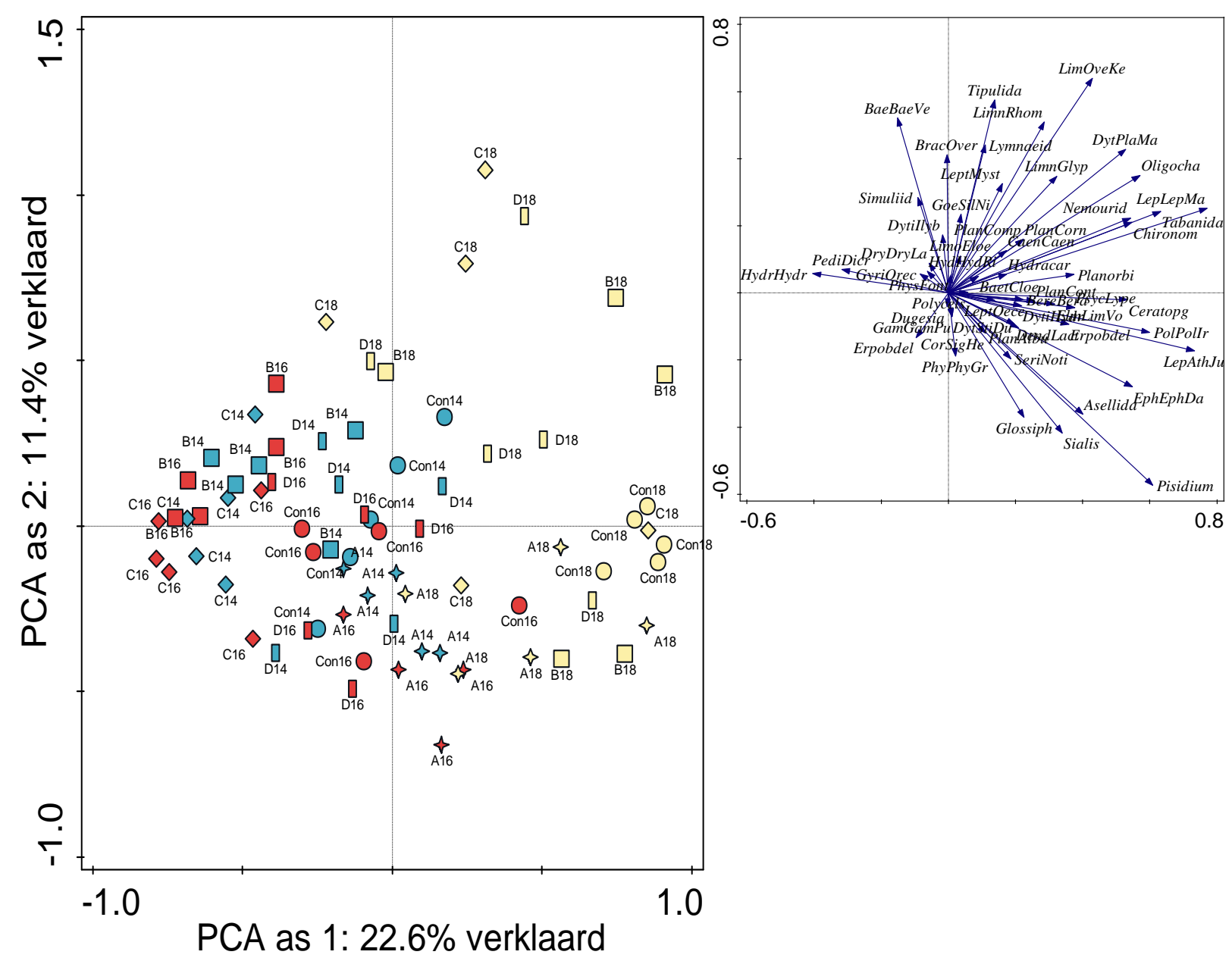

Figuur 3.8: PCA diagram macrofaunasamenstelling monsters afkomstig uit de verschillende zandsuppletiezones in de meetjaren. Verklaring tekens: zone $A$ : ster, zone B: vierkant, zone $C$ : ruit, zone D: rechthoek, controle: cirkel. De jaren zijn met kleuren aangegeven: blauw = 2014 , rood $=2016$ en geel $=2018$. De inzet geeft de spreiding van de taxa weer, waarbij de pijl wijst naar de richting waarin de abundantie van het taxon toeneemt.

Een ordinatie van de taxonsamenstelling van de macrofaunamonsters in de verschillende zones en jaren laat zien dat in 2018 sprake is van een andere samenstelling van de monsters (Figuur 3.8, 2018 gescheiden in de ordinatieruimte aan de rechterkant van het diagram ten opzichte van de links gelegen 2014 en 2016 punten die meer op elkaar geprojecteerd zijn). Verder is er binnen de 2018-monsters sprake van een veel grotere variabiliteit in macrofaunasamenstelling ten opzichte van de jaren ervoor (punten liggen voor het jaar 2018 verder uit elkaar in ordinatiediagram). Wanneer de taxa in het ordinatiediagram bekeken worden dan wordt duidelijk dat er in 2018 sprake is van een duidelijke teruggang in voorkomen van de stromingsminnende kokerjuffer Hydropsyche (code HydrHydr), welke in 2016 op 18 plekken gevonden werd, tegen slechts 3 plekken in 2018 en de muggenlarve Dicronota (Pedidicr) (Tabel 3.3). Beide zijn kenmerkend voor watertype R5.

Het is waarschijnlijk dat zowel het verschijnen van bepaalde stilstaand-water-taxa als een afname in talrijkheid van de aanwezige (stromingsminnende) taxa een effect is van de relatief lage afvoer, waardoor sommige taxa benadeeld worden, terwijl andere worden bevoordeeld. Dit effect is voor de Leuvenumse beek uitgebreid beschreven op basis van de resultaten van een droogval en stagnatieexperiment en beslaat grotendeels dezelfde taxa als in 2018 in de onderzoekstrajecten zijn aangetroffen (Verdonschot et al. 2015). 
Tabel 3.3: Frequentie van voorkomen per meetjaar voor de verschillende suppletiezones en de controle ( $n=5$ locaties per zone).

\begin{tabular}{|c|c|c|c|c|c|c|c|c|c|c|c|c|c|c|c|}
\hline \multirow[t]{2}{*}{ Taxon } & \multicolumn{3}{|l|}{ A } & \multicolumn{3}{|l|}{ B } & \multicolumn{3}{|l|}{ C } & \multicolumn{3}{|l|}{ D } & \multicolumn{3}{|c|}{ Controle } \\
\hline & 14 & 16 & 18 & 14 & 16 & 18 & 14 & 16 & 18 & 14 & 16 & 18 & 14 & 16 & 18 \\
\hline Asellidae & 4 & 2 & 3 & 2 & & 2 & 1 & & 1 & 4 & 2 & 2 & 5 & 3 & 5 \\
\hline Baetidae: Baetis vernus & 3 & 1 & 2 & 5 & 5 & 4 & & 5 & 5 & 3 & & 4 & 3 & 4 & \\
\hline Baetidae: Cloeon & & & 1 & & & & & & & & & 1 & & & 1 \\
\hline Bereidae: Beraeodes & & & & & & & & & & & & & & & 1 \\
\hline Ephydridae & & & & & & & & 1 & 1 & & & 1 & & & \\
\hline Caenidae: Caenis & & & 1 & & & & & & & & & 1 & & & \\
\hline Ceratopogonidae & 2 & 2 & 5 & 1 & 1 & 4 & 3 & & 3 & 4 & 2 & 5 & 5 & 3 & 3 \\
\hline Chironomidae & 5 & 4 & 5 & 5 & 5 & 5 & 3 & 5 & 5 & 5 & 5 & 5 & 3 & 5 & 5 \\
\hline Corixidae: Sigara hellensii & & 1 & 1 & & & & & & & & 1 & 2 & & & \\
\hline Dendrocoelum lacteum & & & & & & & & & & & & & & 1 & 1 \\
\hline Dryopidae: Dryops larve & & & & & & & & & & 1 & & & & & \\
\hline Dugesia & 1 & & & & & & & & & 2 & & & & & \\
\hline Dytiscidae: Hydroporus & & & & & & & & & & & & & & & 1 \\
\hline Dytiscidae: Ilybius & & & & & & & & & & & & 1 & & & \\
\hline $\begin{array}{l}\text { Dytiscidae: Platambus } \\
\text { maculatus }\end{array}$ & 2 & 3 & 3 & & 2 & 3 & & & 5 & 1 & 5 & 5 & 4 & 4 & 5 \\
\hline $\begin{array}{l}\text { Dytiscidae: Stictotarsus } \\
\text { duodecimpustulatus }\end{array}$ & & & 1 & & & & & & & & & & & & \\
\hline Elmidae: Limnius volckmari & & & 2 & 1 & 1 & 2 & & & 1 & & 1 & 2 & & 1 & 3 \\
\hline $\begin{array}{l}\text { Ephemeriidae: Ephemera } \\
\text { danica }\end{array}$ & 5 & 3 & 5 & 4 & 4 & 4 & 3 & 5 & 5 & 5 & 4 & 5 & 5 & 5 & 5 \\
\hline Erpobdellidae:Erpobdella & & 2 & 2 & 2 & 3 & 4 & & 1 & & 3 & 3 & 3 & & 3 & 4 \\
\hline Erpobdellidae:Trocheta & & & & & & & & & & 1 & & & & & \\
\hline Gammaridae: Gammarus pulex & 5 & 4 & 2 & 5 & 5 & 5 & 5 & 5 & 4 & 5 & 5 & 4 & 5 & 5 & 5 \\
\hline Glossiphoniidae: Glossiphonia & 3 & 2 & & & & 1 & 1 & 1 & 1 & 3 & 3 & & & 3 & 5 \\
\hline Goeriidae: Silo nigricornis & & & & & 1 & 1 & & & & & 1 & & & & \\
\hline Gyrinidae: Orectochilus & 1 & & & 4 & 5 & 3 & & 3 & 1 & 2 & 1 & 1 & & 2 & 3 \\
\hline Hydracarina & 4 & 1 & 2 & 4 & 3 & 3 & & 1 & 1 & 3 & 3 & 3 & 2 & 3 & 3 \\
\hline Hydraenidae: Hydraena riparius & & & & & 1 & 1 & & & 1 & & & & & & \\
\hline Hydropsychiidae: Hydropsyche & 1 & & & 5 & 5 & 1 & & 4 & & 1 & 2 & & & & 2 \\
\hline Leptoceridae: Athripsodes & 3 & 2 & 4 & 2 & 1 & 4 & & & 3 & 1 & 1 & 4 & & 2 & 5 \\
\hline Leptoceridae: Mystacides & & & 1 & & & & & & 1 & & & 1 & & & \\
\hline Leptoceridae: Oecetis & & & 1 & & & & & & & & & & & & \\
\hline $\begin{array}{l}\text { Leptophlebiidae: Leptophlebia } \\
\text { marginata }\end{array}$ & 5 & 4 & 5 & 5 & 4 & 5 & 3 & 1 & 5 & 5 & 4 & 5 & 5 & 4 & 5 \\
\hline $\begin{array}{l}\text { Limnephilidae overig: kenm. } \\
\text { Micropterna }\end{array}$ & 1 & & 3 & 2 & & 3 & 4 & 1 & 4 & 4 & 1 & 4 & 4 & 2 & 5 \\
\hline Limnephilidae: Glyphotaelius & 2 & 1 & 1 & 1 & & 2 & & & 2 & 3 & & 3 & 1 & 1 & 2 \\
\hline $\begin{array}{l}\text { Limnephilidae: Limnephilus } \\
\text { rhombicus }\end{array}$ & & & 1 & & 1 & 1 & & 1 & 3 & & 1 & 3 & & 2 & \\
\hline Limoniidae: Eloeophila & 3 & & 1 & 3 & & 3 & 3 & 3 & 3 & 4 & 2 & 4 & 3 & 3 & 2 \\
\hline Lymnaeidae & & & & & & 2 & & & 1 & & & & & & \\
\hline Nemouridae & 5 & 2 & 3 & 5 & 3 & 5 & 4 & 2 & 5 & 5 & 5 & 4 & 5 & 5 & 5 \\
\hline Oligochaeta & 4 & 3 & 5 & 5 & 3 & 5 & 4 & 2 & 4 & 4 & 4 & 5 & 3 & 5 & 5 \\
\hline
\end{tabular}




\begin{tabular}{|c|c|c|c|c|c|c|c|c|c|c|c|c|c|c|c|}
\hline \multirow[t]{2}{*}{ Taxon } & \multicolumn{3}{|l|}{$\mathbf{A}$} & \multicolumn{3}{|l|}{ B } & \multicolumn{3}{|l|}{ C } & \multicolumn{3}{|l|}{ D } & \multicolumn{3}{|c|}{ Controle } \\
\hline & 14 & 16 & 18 & 14 & 16 & 18 & 14 & 16 & 18 & 14 & 16 & 18 & 14 & 16 & 18 \\
\hline Pediciidae: Dicranota & 2 & & & 1 & 3 & & & 3 & & 1 & 2 & 1 & & 2 & \\
\hline $\begin{array}{l}\text { Phyrganeidae: Phyrganea } \\
\text { grandis }\end{array}$ & & 1 & 1 & & & & & & & 1 & & & & & \\
\hline Physiidae: Physa fontinalis & 1 & & & 1 & & & & & & 1 & & & & & \\
\hline Pisidium & 5 & 4 & 5 & 2 & 1 & 5 & & 4 & 2 & 5 & 4 & 2 & 5 & 5 & 5 \\
\hline Planorbidae: Anisus & 1 & 1 & 1 & & & 1 & & & 2 & 1 & & 2 & & & \\
\hline $\begin{array}{l}\text { Planorbidae: Bathyomphalus } \\
\text { contortus }\end{array}$ & & & 1 & & & 1 & & & & & & & & & \\
\hline Planorbidae: Gyraulus albus & & & 1 & & & & & & & & & & & & \\
\hline $\begin{array}{l}\text { Planorbidae: Hippeutis } \\
\text { complanatus }\end{array}$ & & & & & & 1 & & & & & & & & & \\
\hline $\begin{array}{l}\text { Planorbidae: Planorbarius } \\
\text { corneus }\end{array}$ & & & & & & 1 & & & & & & & & & \\
\hline Polycelis & & 1 & & & & & & & & 2 & & 1 & 1 & & \\
\hline $\begin{array}{l}\text { Polycentropodidae: } \\
\text { Polycentropus } \\
\text { irroratus/Plectrocnemia } \\
\text { conspersa }\end{array}$ & 4 & 2 & 2 & 2 & 2 & 5 & & 1 & 2 & 2 & 1 & 1 & 1 & 2 & 5 \\
\hline Psychomyiidae: Lype & & & & & & 2 & & & 1 & & & & & & 2 \\
\hline Sericostomatidae: Notidobia & & & 1 & & & 1 & & & 1 & & & & & & 1 \\
\hline Sialis & 4 & 4 & 5 & & & 3 & & 1 & & 2 & 2 & 4 & & & 2 \\
\hline Simuliidae & 1 & & & 3 & 1 & 2 & & 1 & 1 & 1 & & & 1 & & \\
\hline Tabanidae & 1 & & 2 & & & 4 & & 1 & 4 & 1 & 2 & 4 & 1 & & 5 \\
\hline Tipulidae & & & & & & 1 & & & 2 & & & 1 & & & \\
\hline
\end{tabular}

$\underline{\text { Vis }}$

$\overline{\mathrm{Er}}$ zijn tijdens het bemonsteren van de macrofauna twee vissoorten aangetroffen, het bermpje en de rivierdonderpad. Beide soorten zijn in alle drie de jaren gevonden (Tabel 3.4). Het armst aan vissen was zone A (depositiezone), het rijkst zone B (gestabiliseerde suppletiezone). Ondanks de lage afvoer in 2018 was het aantal aangetroffen bermpjes gelijk aan 2016, voor rivierdonderpad lag dit aantal in 2018 lager.

Tabel 3.4: Bijvangst van vissen tijdens de macrofaunabemonsteringen van de suppletiezones in de drie meetjaren.

\begin{tabular}{|c|c|c|c|c|c|c|c|c|}
\hline \multirow[t]{2}{*}{ Zone } & \multirow[t]{2}{*}{ Locatie } & \multicolumn{3}{|c|}{ Bermpje (\# individuen) } & \multicolumn{3}{|c|}{ Rivierdonderpad (\# individuen) } & \multirow{2}{*}{$\begin{array}{l}\text { Totaal } \\
\text { \# per } \\
\text { zone }\end{array}$} \\
\hline & & 2014 & 2016 & 2018 & 2014 & 2016 & 2018 & \\
\hline \multirow[t]{5}{*}{$A$} & $\mathrm{Z1}$ & & & & & & & \multirow{5}{*}{1} \\
\hline & Z2 & & & & & & & \\
\hline & $\mathrm{Z3}$ & & & & & & & \\
\hline & Z4 & 1 & & & & & & \\
\hline & $\mathrm{Z5}$ & & & & & & & \\
\hline \multirow[t]{5}{*}{$B$} & Z1 & 1 & 1 & & 1 & & & \multirow{5}{*}{16} \\
\hline & $\mathrm{Z2}$ & 1 & & & 2 & 1 & & \\
\hline & Z3 & & & 2 & & 1 & 1 & \\
\hline & Z4 & 1 & & & 1 & 1 & & \\
\hline & $\mathrm{Z5}$ & & 1 & & & 1 & & \\
\hline
\end{tabular}




\begin{tabular}{|c|c|c|c|c|c|c|c|c|}
\hline \multirow[t]{5}{*}{ C } & Z1 & & 1 & & & & & \multirow{5}{*}{5} \\
\hline & $\mathrm{Z2}$ & & 3 & & & & & \\
\hline & Z3 & & & 1 & & & & \\
\hline & Z4 & & & & & & & \\
\hline & $\mathrm{Z5}$ & & & & & & & \\
\hline \multirow[t]{5}{*}{$\mathrm{D}$} & $\mathrm{Z1}$ & & 2 & 1 & & 1 & & \multirow{5}{*}{8} \\
\hline & $\mathrm{Z2}$ & & 1 & & & & & \\
\hline & Z3 & & & 1 & & & & \\
\hline & Z4 & 1 & & 1 & & & & \\
\hline & Z5 & & & & & & & \\
\hline \multirow[t]{5}{*}{ Controle } & C1 & & & & & & & \multirow{5}{*}{6} \\
\hline & C2 & & 1 & & & & & \\
\hline & C3 & & & 2 & & & 1 & \\
\hline & C4 & & & & & & & \\
\hline & C5 & & & 2 & & & & \\
\hline \multicolumn{2}{|c|}{ Totaal \# per jaar } & 5 & 10 & 10 & 4 & 5 & 2 & 36 \\
\hline
\end{tabular}




\section{Macrofauna van het beekmoeras}

\subsection{Inleiding}

Aanvullend zijn vanaf 2014 een aantal trajecten bovenstrooms van de meest bovenstrooms gelegen suppletielocatie Z1 gemonitord met het idee dat deze trajecten als controle voor de trajecten met zandsuppletie konden dienen. Hier loopt de beek door een relatief grote laagte. Echter bleek al snel dat onder invloed van het benedenstrooms gelegen projectgebied (via opstuwing door verondieping van de beekbedding als gevolg van de zandsuppleties) er vernatting optrad, waardoor de beek hier steeds meer een moeraskarakter kreeg en de laagte langdurig geinundeerd was (Figuur 4.1). Besloten is deze moerasontwikkeling te volgen. Juist deze beek-begeleidende moerassen lijken een belangrijke meerwaarde te hebben voor de beekecologie (in termen van kenmerkende soorten voor het KRW-type R5 en het nieuwe KRW-type 'moerasbeek' R20), maar zijn nog zelden onderzocht. Om de (meer)waarde van de ontwikkelingen langs de Leuvenumse beek in te kunnen schatten is de macrofauna van de moerasbeek in 2018 beter bekeken. De volgende vragen worden behandeld in dit hoofdstuk:

1. Hoe ontwikkelt het beekprofiel zich bij vermoerassing?

2. Wat is de waarde van het moerasbeektraject voor de macrofauna ten opzichte van andere beektrajecten in termen van ecologische kwaliteit en het voorkomen van kenmerkende soorten?

\subsection{Aanpak}

\section{Beekprofiel moerasbeek}

De veranderingen in bodemhoogte zijn voor drie transecten vastgelegd (C1.1, C1.2 en $\mathrm{C} 1.3$, Figuur 2.1), waarbij de eerste metingen in oktober 2014 plaatsvonden, analoog aan de transecten bij de suppletielocaties (zie hoofdstuk 2). De verandering in bodemhoogte is in de tijd vastgelegd (Bijlage 2) door telkens een meting in het voorjaar en het najaar uit te voeren. In deze rapportage vergelijken we de meting van oktober 2014 met die van april en september 2016, 2017 en 2018. Gekozen is voor een voorjaars- en najaarsmeting. De voorjaarsmeting geeft de situatie na een periode van hoge afvoeren in de winter, de najaarsmeting (tijdens relatief lage afvoer) kan worden beschouwd als een uitgangssituatie voor een nieuwe periode met hoge afvoeren later in het jaar.

\section{Macrofauna moerasbeek}

Om de ecologische status van de moerasbeek vast te stellen zijn er op drie locaties 5-mstandaard-macrofaunanet-monsters genomen: een monster van de moerasbeek (met deelmonsters van de beekloop en van het op dat moment geinundeerde moeras), een monster van het gesuppleerde traject net benedenstrooms Z1 (met alleen smalle overstromingszones die alleen bij hoog water geinundeerd zijn) en een gekanaliseerd controletraject bovenstrooms in halfopen landschap (t.h.v. de Koekoek).

leder monster omvatte 10 deelmonsters van een halve meter van de aanwezige habitats, waarbij naar de in het veld aanwezige habitatverhouding geschept werd. Relevante milieuvariabelen zijn op een veldformulier genoteerd, zoals bedekkingspercentages van de substraten, stroomsnelheid, beschaduwing etc. Het verzamelde materiaal is in het laboratorium levend uitgezocht en tot op een zo laag mogelijk taxonomisch niveau gedetermineerd. Vervolgens is de taxonsamenstelling tussen de drie locaties vergeleken op basis van taxonrijkdom, kenmerkende soorten en de ecologische kwaliteit die door de levensgemeenschap geindiceerd wordt. 

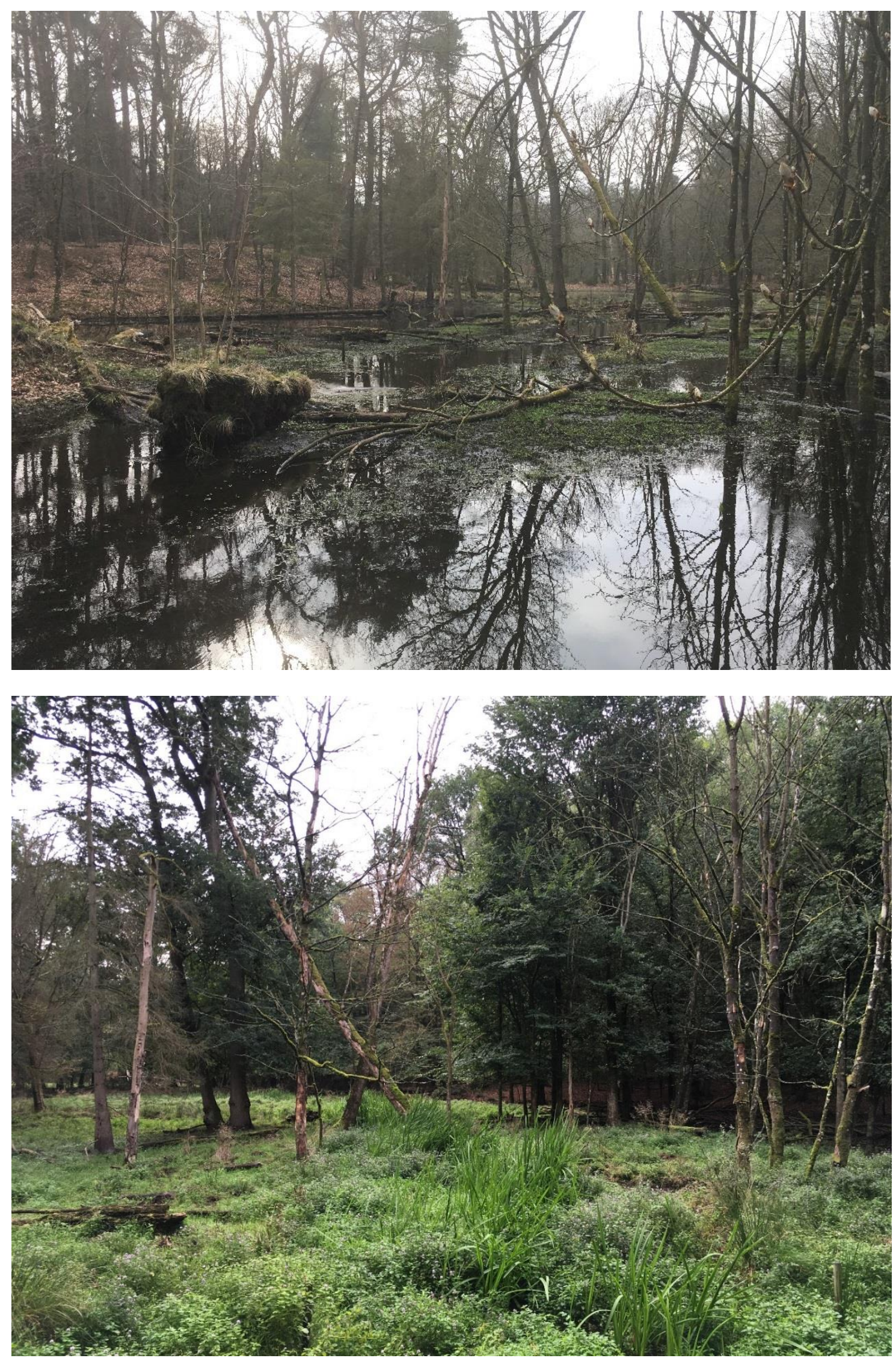

Figuur 4.1: Moerasbeektraject in het voorjaar (boven) en het najaar (onder) 2018. 


\subsection{Resultaten}

\section{Beekprofiel moerasbeek}

Het controletraject bovenstrooms van Z1 heeft zich in de afgelopen jaren ontwikkeld tot een moerasbeek met permanent natte oeverzones met veel moerasvegetatie (Figuur 4.2).

Kenmerkend voor dit traject is de sterk wisselende profielvorm over de afgelopen jaren (Bijlage 2). De verschillen hangen waarschijnlijk samen met enerzijds de massale vegetatieontwikkeling die zorgt voor slibinvang en het ontstaan van slibbanken langs de oevers en anderzijds de activiteiten van wilde zwijnen die zorgen dat plekken weer open worden gemaakt (zoelplekken), waarna het slib naar benedenstrooms verdwijnt.

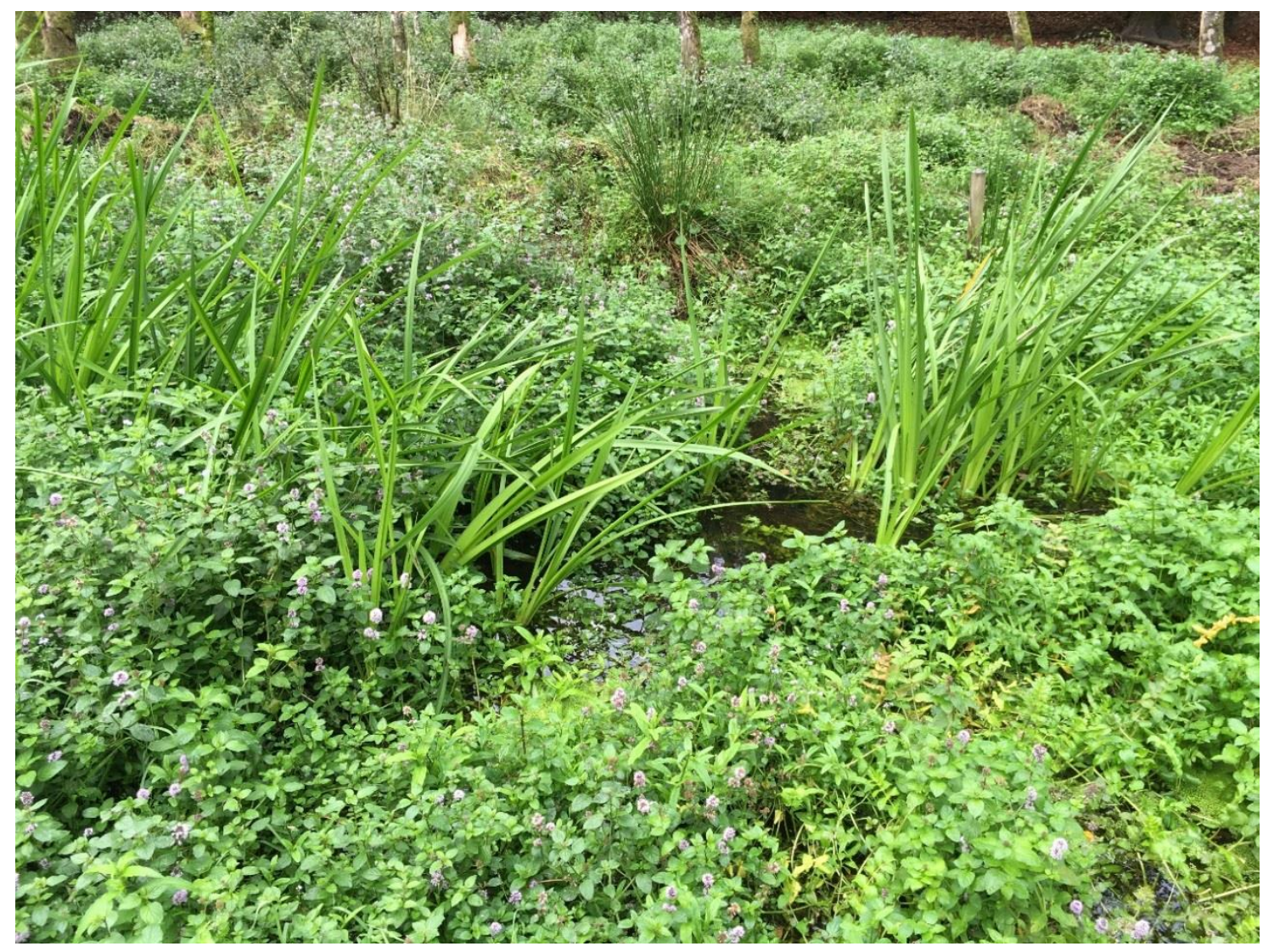

Figuur 4.2: Controletraject $C$ (net bovenstrooms suppletielocatie Z1) in september 2018, midden in de extreme droogteperiode. De beek en aanliggende zone is permanent nat gebleven, waardoor de moerasvegetatie zich heeft gehandhaafd. 


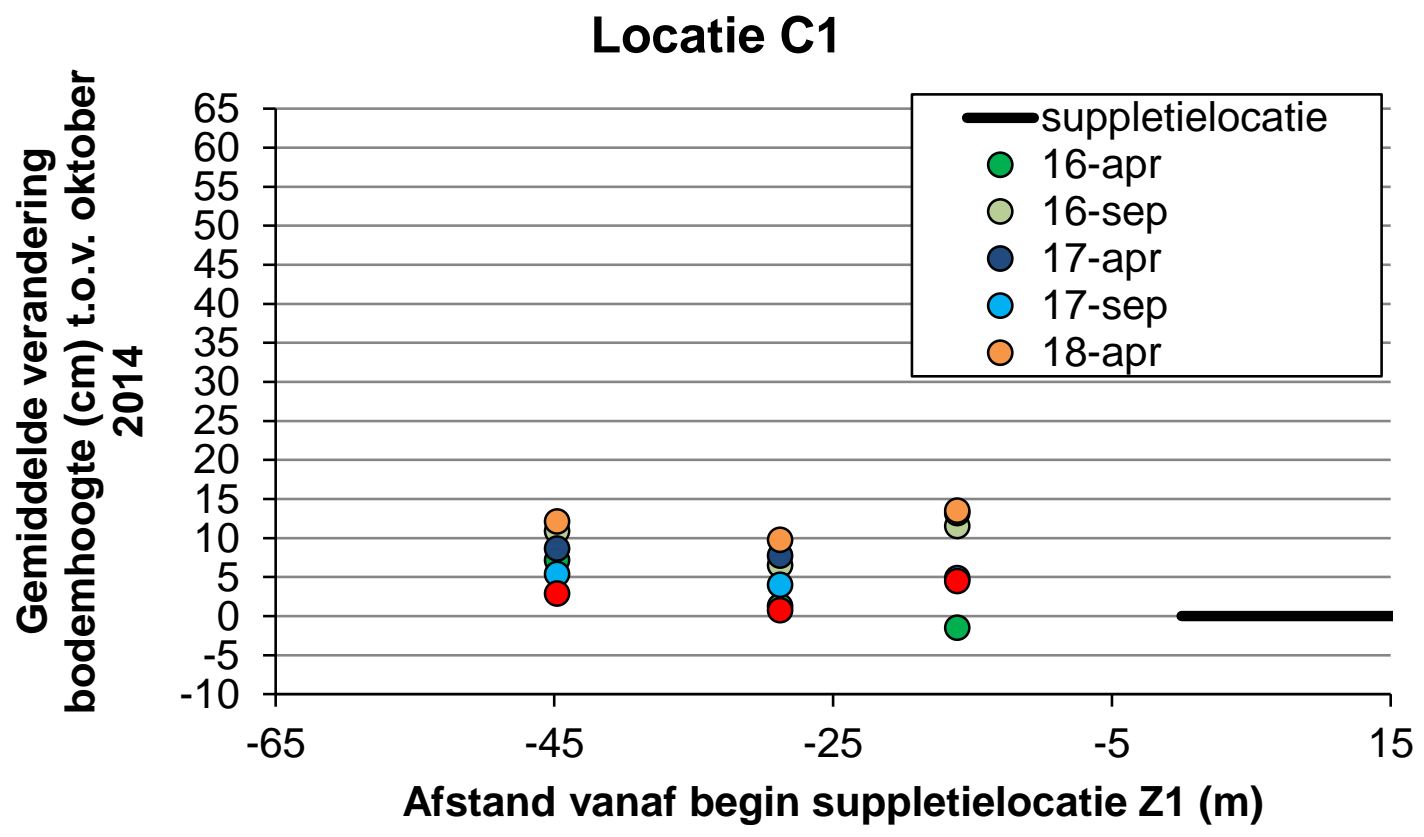

Figuur 4.3: Verandering van de gemiddelde bodemhoogte in de beektrajecten C1.1-C1.3 ten opzichte van de situatie in oktober 2014 (= nullijn).

Macrofauna moerasbeek

Wanneer de trajecten vergeleken worden op basis van hun fysisch-chemische omstandigheden, dan verschilde het moerastraject niet van de andere twee trajecten (Tabel 4.1). Wel was de stroomsnelheid er lager en was er een andere substraatbedekking aanwezig, waar fijn organisch materiaal en waterplanten veel nadrukkelijker aanwezig waren.

Tabel 4.1: Karakteristieken meetpunten op 9 april 2018.

\begin{tabular}{|c|c|c|c|c|}
\hline \multicolumn{2}{|l|}{ Parameters } & \multicolumn{3}{|l|}{ Traject } \\
\hline Coordinaten locaties & $\mathrm{X}$ & \begin{tabular}{|l|}
$\begin{array}{l}\text { Controle } \\
\text { Koekoeek }\end{array}$ \\
177.333
\end{tabular} & $\begin{array}{l}\mathbf{Z 1} \\
\text { suppletie } \\
177.094\end{array}$ & $\begin{array}{l}\begin{array}{l}\mathbf{Z 1} \\
\text { moeras }\end{array} \\
177.141\end{array}$ \\
\hline & $\mathrm{Y}$ & 479.905 & 481.155 & 481.107 \\
\hline \multirow[t]{5}{*}{ Fysisch-chemische parameters } & Watertemperatuur $\left({ }^{\circ} \mathrm{C}\right)$ & 13.8 & 13.1 & 13.6 \\
\hline & Zuurstofgehalte $\left(\mathrm{mg} \mathrm{O}_{2} / \mathrm{L}\right)$ & 9.5 & 9.5 & 9.4 \\
\hline & Zuurstofverzadiging (\%) & 93 & 91 & 91 \\
\hline & Geleidbaarheid $(\mu \mathrm{S} / \mathrm{cm})$ & 283 & 290 & 294 \\
\hline & Zuurgraad & 7.1 & 7.0 & 7.1 \\
\hline Hydrologie & $\begin{array}{l}\text { Stroomsnelheid stroomdraad } \\
(\mathrm{cm} / \mathrm{s})\end{array}$ & 26 & 20 & 15 \\
\hline \multirow[t]{9}{*}{ Substraat } & Grind & $<5$ & 5 & - \\
\hline & Zand & 70 & 45 & $<5$ \\
\hline & Hout & 10 & 20 & $<5$ \\
\hline & Grove detritus & 15 & 10 & 30 \\
\hline & Fijne detritus & $<5$ & 20 & 60 \\
\hline & Vegetatie emers & - & $<5$ & 20 \\
\hline & Vegetatie submers & $<5$ & 5 & 10 \\
\hline & Vegetatie drijvend (kroos) & - & $<5$ & $<5$ \\
\hline & Draadalg & - & - & $<5$ \\
\hline
\end{tabular}


De ecologische kwaliteit van de drie bemonsterde trajecten op basis van de macrofauna scoort op de R5-maatlat (langzaam stromende midden-benedenloop op zand) goed en op basis van de nieuwe maatlat voor moerasbeken (R20) zeer goed. Het aantal kenmerkende taxa is in dezelfde orde van grootte voor alle drie de bemonsterde locaties, maar wat betreft unieke taxa dragen zowel de controle als het moerastraject net iets meer bij dan de suppletielocatie (Tabel 4.2, Bijlage 3), wat wil zeggen dat in het suppletietraject meer taxa voorkomen die ook in andere trajecten gevonden worden. De verschillen zijn echter klein. Het moerastraject bevat de kokerjuffer Polycentropus irroratus, de wantsen Sigara hellensii en Sigara fossarum, de vedermuggen Natarsia sp., Rheocricotopus fuscipes en

Thienemanniella flaviforceps agg. en tenslotte de watermijt Arrenurus buccinator als unieke kenmerkende soorten ten opzichte van de andere locaties. De meeste van deze taxa zijn gebonden aan relatief voedselrijk maar helder stilstaand tot langzaam stromend water met een goede zuurstofvoorziening en rijk aan waterplanten.

Tabel 4.2: Ecologische kwaliteit monsterlocaties in april 2018 op basis van de maatlatten voor R5 en R20 (moerasbeek).

\begin{tabular}{|l|l|l|l|l|}
\hline KRW-watertype & Parameter & Locatie & \multicolumn{2}{|l|}{} \\
\cline { 3 - 5 } & & Controle_koekoek & Z1_suppletie & Z1_moeras \\
\hline R5 & EKR & 0.78 & 0.73 & 0.64 \\
\cline { 2 - 5 } & $\begin{array}{l}\text { Kenmerkende } \\
\text { taxa totaal }\end{array}$ & 15 & 14 & 12 \\
\cline { 2 - 5 } & $\begin{array}{l}\text { Aantal unieke } \\
\text { kenmerkende } \\
\text { taxa }\end{array}$ & 5 & 2 & 4 \\
\hline R20 (moerasbeek) & EKR & 0.87 & 0.85 & 0.83 \\
\cline { 2 - 5 } & $\begin{array}{l}\text { Kenmerkende } \\
\text { taxa totaal }\end{array}$ & 12 & 12 & 13 \\
\cline { 2 - 5 } & $\begin{array}{l}\text { Aantal unieke } \\
\text { kenmerkende } \\
\text { taxa }\end{array}$ & 4 & 3 & 6 \\
\hline
\end{tabular}




\section{Discussie en conclusies}

\section{Dwarsprofieltransectmetingen}

Drie jaar na de laatste suppletie is nog steeds een duidelijke ophoging van de beekbodem zichtbaar ten opzichte van 2014. Dit heeft geleid tot verondiepte en verkleinde profielen. $\mathrm{Er}$ vindt echter nog steeds zandtransport plaats. Deels bestaat dit uit een jaarlijks terugkerend patroon met ophoging in het voorjaar (na afvoerpieken), gevolgd door erosie waardoor bodemdaling wordt gemeten in het najaar. Deze afvoergerelateerde sedimentpulsen leiden tot een langzame verplaatsing van zand naar benedenstrooms, waar nog steeds ophoging plaatsvindt. Drie jaar na de laatste suppletie treed dus nog steeds een netto verplaatsing van sediment naar benedenstrooms op. Een tweede aanjager van het transport zijn lokale veranderingen van de stromingspatronen in de beek door plotselinge veranderingen in de beek, met name door de natuurlijke aanvoer van nieuw dood hout maar ook door activiteiten in de beek van grote zoogdieren (zoelplekken wild zwijn, oversteekplaatsen) en recreanten (bijv. vergravingen om dammen te bouwen).

De verondieping en profielverkleining heeft een aantal voor het beekecosysteem gunstige eigenschappen, zoals behoud van relatief hoge stroomsnelheid bij lage afvoer en het snel buiten de oevers treden van de beek bij hoge afvoer, waardoor een natte overstromings- of moeraszone ontstaat. Dit laatste treedt in de onderzochte trajecten alleen op bij Z1, omdat de hier al aanwezige laagtes aantakt zijn door de beekbodemophoging. De veranderingen in de vegetatie door een combinatie van vernatting en meer licht door het afsterven van bomen ten opzichte van de situatie in 2014 zijn hier dan ook duidelijk zichtbaar. In de beek zelf is hier een heterogeen mozaiek ontstaan van vegetatie, zand, grind en bladpakketten. Hogere stroomsnelheden in combinatie met structuurvariatie door de vegetatie en dood hout heeft hier geleid tot een hogere substraatheterogeniteit.

Het is niet bekend of de maatregelen hebben geleid tot het langer watervoerend blijven van de bestudeerde trajecten dan tijdens eerdere droge zomers (bijvoorbeeld 1976).

\section{Macrofauna suppletielocaties}

In 2018 was de taxonrijkdom beduidend hoger dan in de voorgaande bemonsteringsjaren, maar dit was deels het gevolg van het verschijnen van soorten die typisch zijn voor stilstaand water, oftewel samenhangend met de lage afvoeren door de droogte van 2018. De meeste kenmerkende taxa handhaafden zich ondanks de lage afvoeren, slechts twee taxa lieten een duidelijke teruggang in de frequentie van voorkomen zien. Daar stond tegenover dat er ook een aantal kenmerkende soorten nieuw zijn waargenomen in de trajecten in het projectgebied. Overigens waren deze taxa niet nieuw voor het stroomgebied en in eerdere bemonsteringen (routinematig meetnet, andere projecten) ook aangetroffen. Andere kenmerkende taxa, zoals de op landelijke schaal zeldzame waterwants Sigara hellensii bleken zich verder te hebben uitgebreid over het projectgebied. Het was verder opvallend dat er een grotere variabiliteit in taxonsamenstelling aanwezig was tussen de individuele monsters ten opzichte van de eerdere bemonsteringen.

Er zijn verschillende mogelijke verklaringen voor het verschijnen van nieuwe taxa of populatieuitbreiding in het projectgebied. Uiteraard speelt toeval oftewel trefkans bij de bemonstering een rol, maar het kan ook te maken hebben met een verdere rijping van de trajecten. De dynamische zone $\mathrm{C}$ van de suppletieplekken liet ondanks de nog steeds aanwezige dynamiek bijvoorbeeld een stijging van het aantal (kenmerkende) taxa zien in de tijd. Daarnaast kunnen de grote piekafvoeren in de winter 2017-2018 gezorgd hebben voor het inspoelen van organismen vanuit bovenstrooms gelegen trajecten, welke de suppletietrajecten kunnen hebben gekoloniseerd. Het zou kunnen dat zowel kolonisatie als rijping van traject tot traject verschillen, wat de variabiliteit kan verklaren. Andersom geredeneerd kan de variabiliteit ook een teken zijn van verstoring, in de vorm van ofwel piekafvoeren waarbij pleksgewijs dieren zijn weggespoeld ofwel de plaatselijke impact van de lage afvoeren, waardoor de verschillen tussen de monsterlocaties zijn vergroot. 
De gestabiliseerde zone op de suppletielocaties (zone B) herbergt een relatief groot aantal kenmerkende taxa, maar de controlelocatie bleek in 2018 het grootste aantal kenmerkende taxa te bevatten. De controlelocatie (ter hoogte van de Koekoek) voerde relatief meer water dan de meer benedenstrooms gelegen suppletielocaties ten tijde van de bemonstering. Dit zou een verklaring kunnen zijn voor dit relatief hoge aantal taxa; mogelijk dat de lage afvoeren benedenstrooms een negatieve invloed hebben gehad op het voorkomen van kenmerkende taxa op deze locaties. Echter bleek de faunasamenstelling van de tijdelijk drooggevallen locatie Z5 niet armer dan de eerdere monsters die in dit traject genomen zijn. Kortom, in 2018 zijn zowel soorten verschenen als in aantal afgenomen en er zijn verschillende factoren (de onwikkelingen op de suppletieplekken, de droogte, de hoge winterpiekafvoeren), al dan niet in samenhang, die hiervoor verantwoordelijk kunnen zijn. In het totaal aantal taxa zijn er geen verschillen meer waarneembaar tussen de verschillende suppletiezones en de controle, voor het aantal kenmerkende taxa geldt dat de controle en de gestabiliseerde zone op de suppletieplekken de hoogste aantallen kenmerkende taxa herbergen. Het is dus waarschijnlijk dat met verdere rijping en stabilisatie van de zandtong de aantallen taxa benedenstrooms van de suppletie in de tijd nog verder gaan toenemen.

\section{Macrofauna beekmoeras}

Ondanks de veranderde omstandigheden in het beekmoeras ten opzichte van de oorspronkelijke beekloop, met minder stroming en meer waterplanten en organisch materiaal, wordt de ecologische kwaliteit als goed beoordeeld op basis van de KRW maatlat voor R5 en zelfs zeer goed op basis van de nieuwe moerasbeekmaatlat. Het beekmoeras draagt bij aan de totale biodiversiteit van het stroomgebied omdat er een aantal taxa zijn gevonden die niet op de andere locaties zijn aangetroffen. Het gaat hier met name om aan waterplantenvegetaties gebonden taxa die voorkomen bij relatief langzaam stromende tot stilstaande voedselrijke maar wel heldere en zuurstofrijke omstandigheden. Deze komen voor naast de beekgebonden kenmerkende taxa typisch voor het hele Hierdense beek stroomgebied, zoals de haft Leptophlebia marginata en steenvliegen van het genus Nemoura. 


\section{Aanbevelingen}

Dwarsprofieltransectmetingen

Er treedt nog steeds verplaatsing van zand naar benedenstrooms op, mogelijk versterkt door de zeer hoge afvoeren van de winter 2017-2018 en een grote aanvoer van nieuw dood hout als gevolg van storm. De vraag is hoe dit zich voortzet en of er uiteindelijk een evenwicht instelt. Geadviseerd wordt de metingen daarom vooralsnog in de huidige frequentie (1x voorjaar, $1 \times$ najaar) voort te zetten.

Macrofauna suppletielocaties

Ten opzichte van de jaren 2014 en 2016 week het jaar 2018 duidelijk af wat betreft samenstelling van de levensgemeenschap. Hierbij lijkt in ieder geval de droogte van 2018 een rol te spelen. Aangezien de populatie van bepaalde kenmerkende soorten (bijv. Hydropsyche kokerjuffers) lijkt te zijn afgenomen, is het belangrijk in 2020 een nieuwe bemonstering uit te voeren om te bekijken of de verandering van tijdelijke aard is geweest of dat er meer structureel een verschuiving van de taxonsamenstelling heeft plaatsgevonden.

\section{Macrofauna moeras}

Het moerasbeektraject bevat unieke kenmerkende taxa (zowel voor het watertype R5 als het nieuwe watertype R20-moerasbeek) en draagt zo bij aan de totale biodiversiteit van het gebied. Aangezien het traject nog relatief jong is en volop in ontwikkeling, bijvoorbeeld wat betreft vegetatie, is het waardevol om hier over een aantal jaren een vervolgbemonstering uit te voeren. 


\section{Literatuur}

Verdonschot, R.C.M., Verdonschot P.F.M. 2017b. Monitoring effecten zandsuppletie Leuvenumse beek 2017. Notitie Zoetwatersystemen, Wageningen Environmental Research, Wageningen UR, Wageningen.

Verdonschot, R.C.M., Dekkers, T.B.M. \& P.F.M. Verdonschot, 2017a. Monitoring effecten zandsuppletie Leuvenumse beek 2016. Notitie Zoetwatersystemen, Wageningen Environmental Research, Wageningen UR, Wageningen.

Verdonschot, R.C.M., Dekkers, D.D., Besse-Lotoskaya, A.A. \& P.F.M. Verdonschot, 2016a. Zandsuppletie in de Leuvenumse beek: monitoring van de fysische en biologische effecten 2014-2015. Zoetwatersystemen, Alterra Wageningen UR, Wageningen.

Verdonschot, R., Runhaar, H., Buijse, T., Bijkerk, R. \& P. Verdonschot, 2016b. Doorstroommoerassen en moerasbeken. Typebeschrijvingen en ontwikkeling maatlatten voor de biologische kwaliteitselementen. Notitie Zoetwatersystemen, Alterra Wageningen UR, Wageningen.

Verdonschot, R.C.M., van Oosten-Siedlecka, A.M., ter Braak, C.J.F., Verdonschot, P.F.M. (2015) Macroinvertebrate survival during cessation of flow and streambed drying in a lowland stream. Freshwater Biology 60: 282-296. 


\section{Bijlage 1: dwarsprofielen van de suppletielocaties}

De transecten zijn gestandaardiseerd op de hoogte van de paal op de linker-oever.

\section{Traject Z1}

Ligging transecten $(1 \mathrm{t} / \mathrm{m} 3=\mathrm{a}, 4 \mathrm{t} / \mathrm{m} 6=\mathrm{b}, 7 \mathrm{t} / \mathrm{m} 9=\mathrm{c})$ :

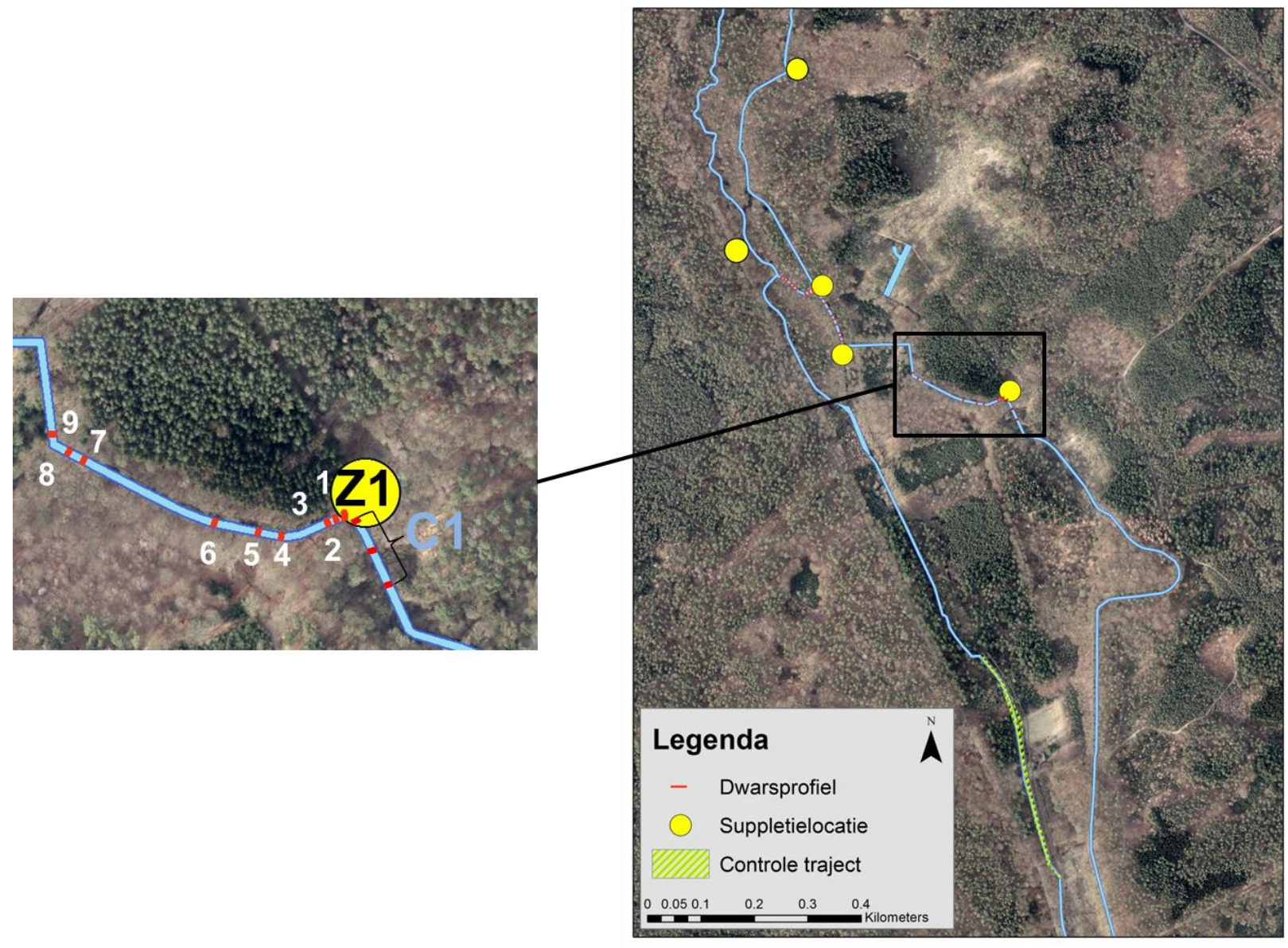




\section{Z1.1a}

$\leftarrow$-okt-14 $\leadsto$ apr-16 $\leftarrow$ sep-16 $*$ apr-17

* sep-17-apr-18 + sep-18
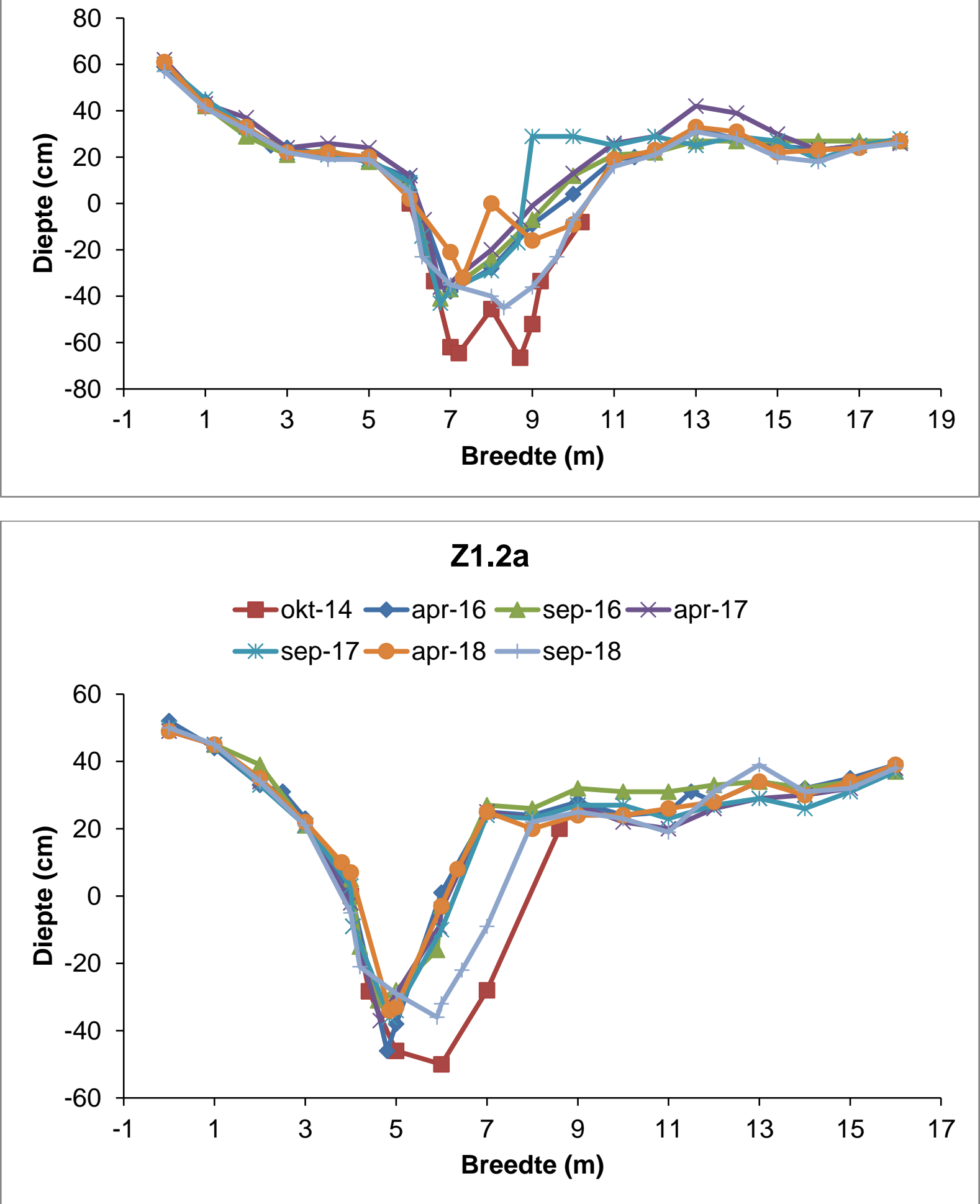


\section{Z1.3a}

$\neg$-okt-14 $\leadsto$-apr-16 $\leftarrow$ sep-16 $*$ apr-17

* sep-17-c-apr-18 + sep-18

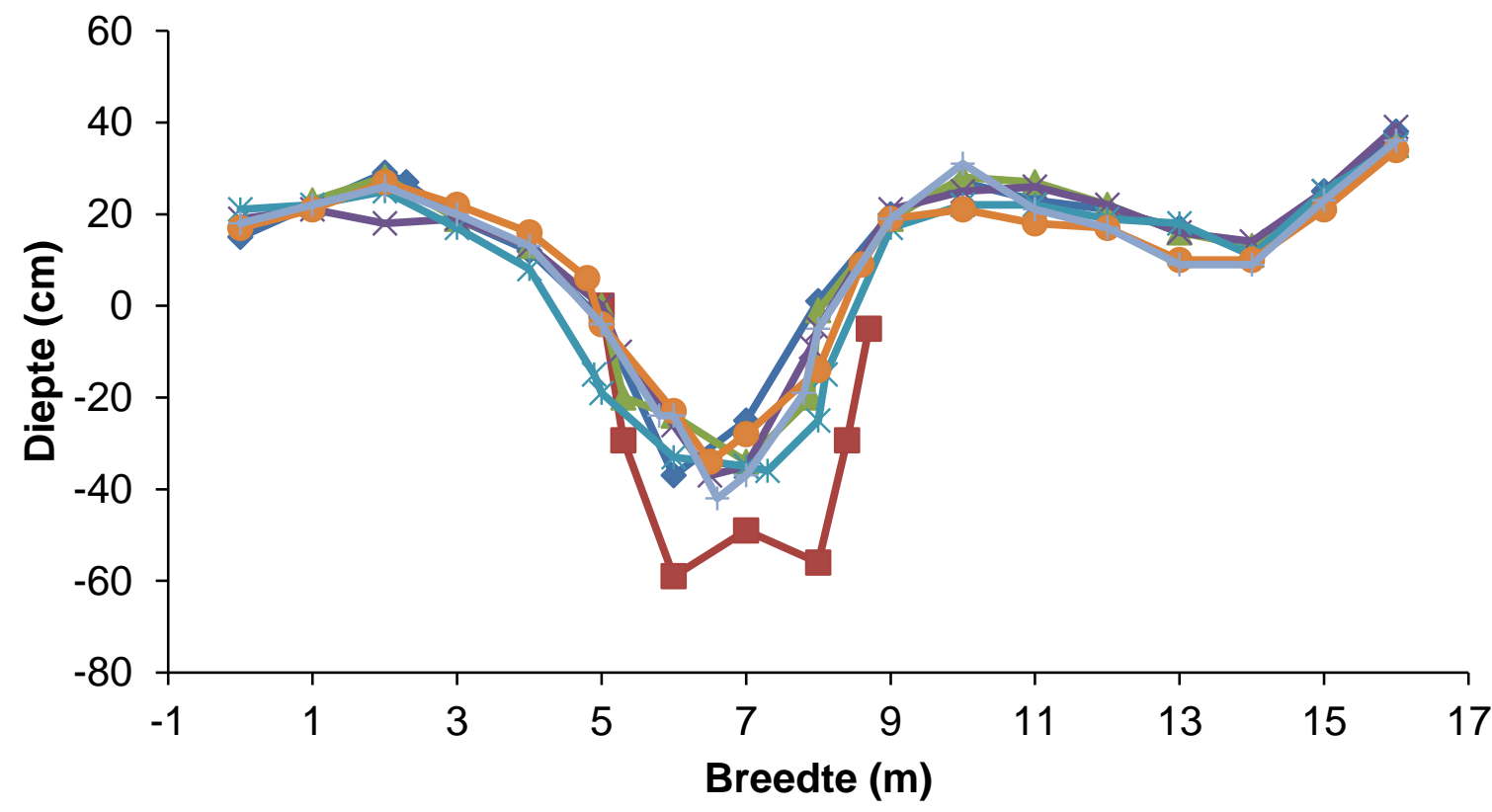

\section{Z1.4b}

$\dashv$-okt-14 -apr-16 $\leftarrow$ sep-16 $*$ apr-17

* sep-17-apr-18 - sep-18

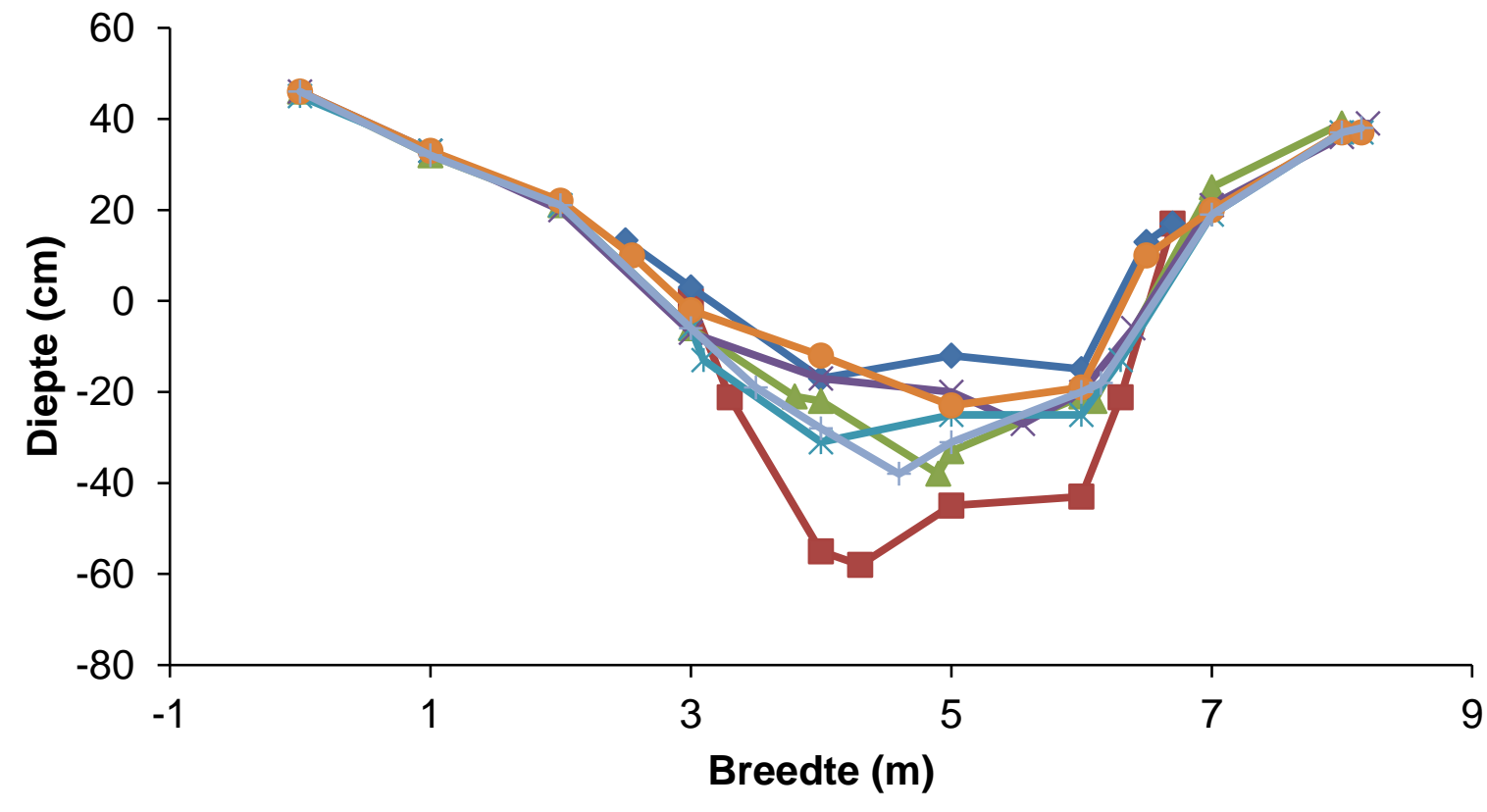




\section{Z1.5b}

$\neg$-okt-14 $\leadsto$ apr-16 $\leftarrow$ sep-16 $*$ apr-17

* sep-17-o-apr-18 + sep-18

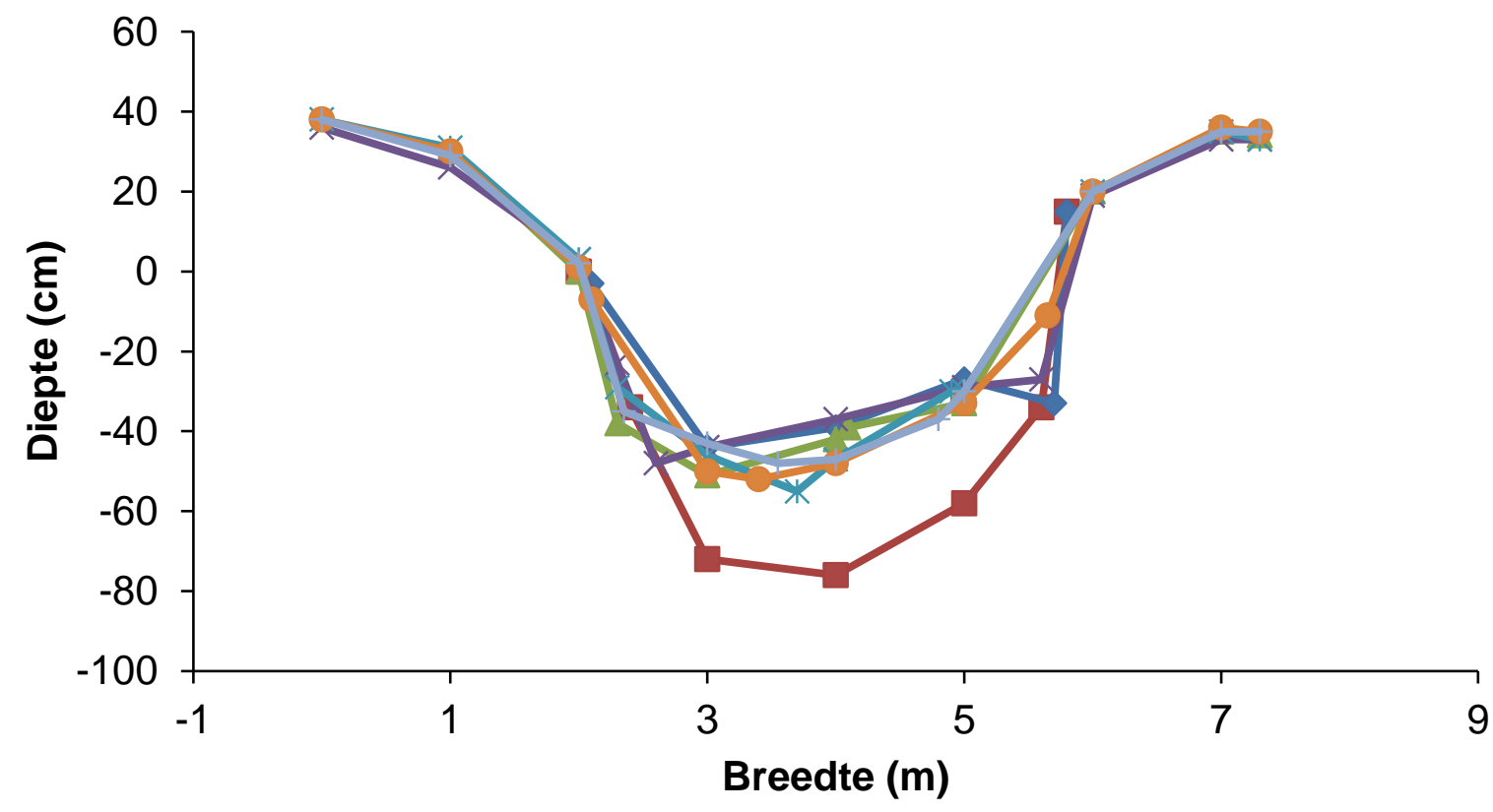

\section{Z1.6b}

$\leftarrow$-okt-14 $\leadsto$ apr-16 $\leftarrow$ sep-16 $*$ apr-17

* sep-17-a-apr-18 + sep-18

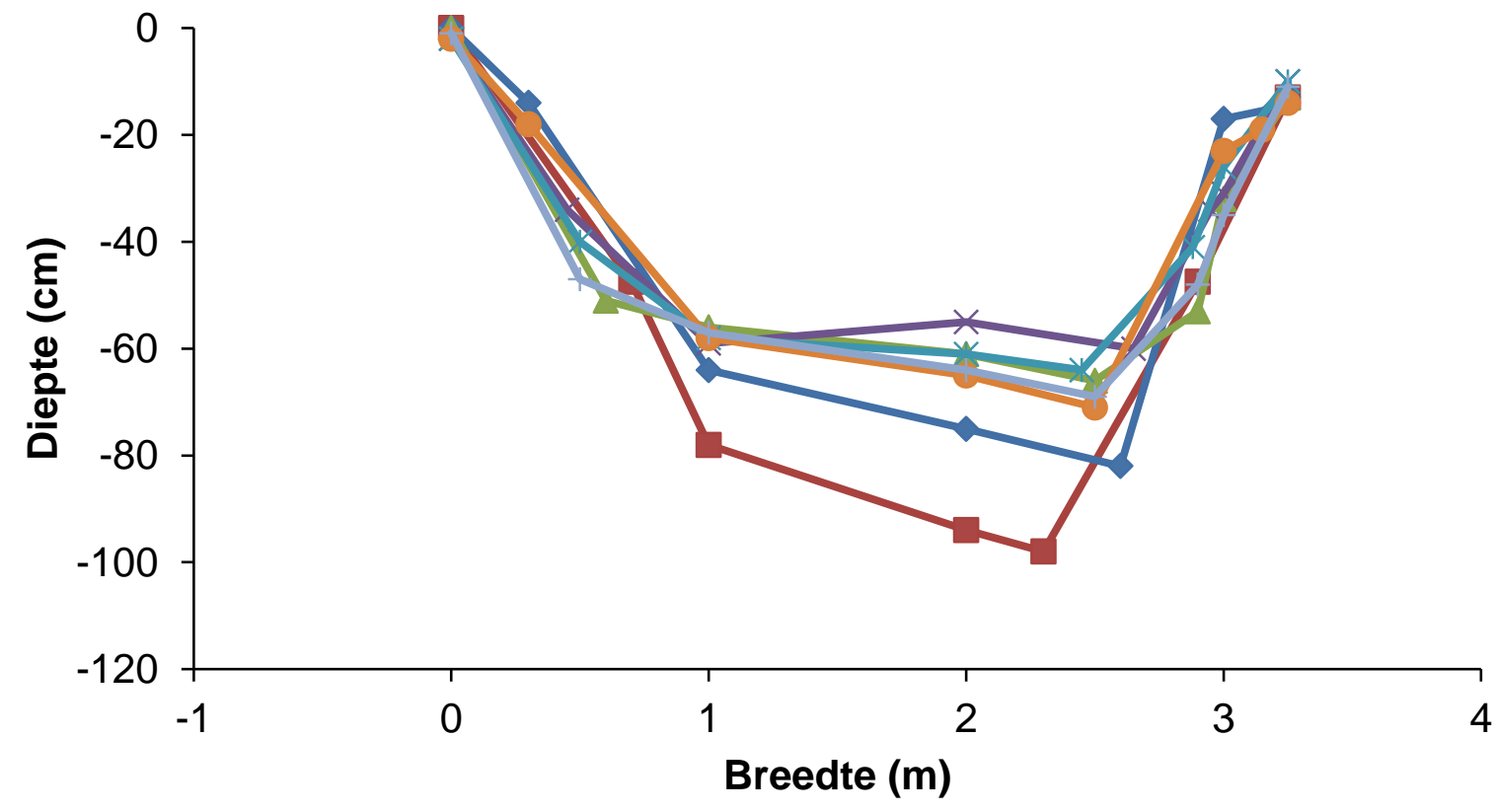




\section{Z1.7c}

-okt-14 -apr-16 - sep-16 *apr-17

* sep-17-o-apr-18 + sep-18

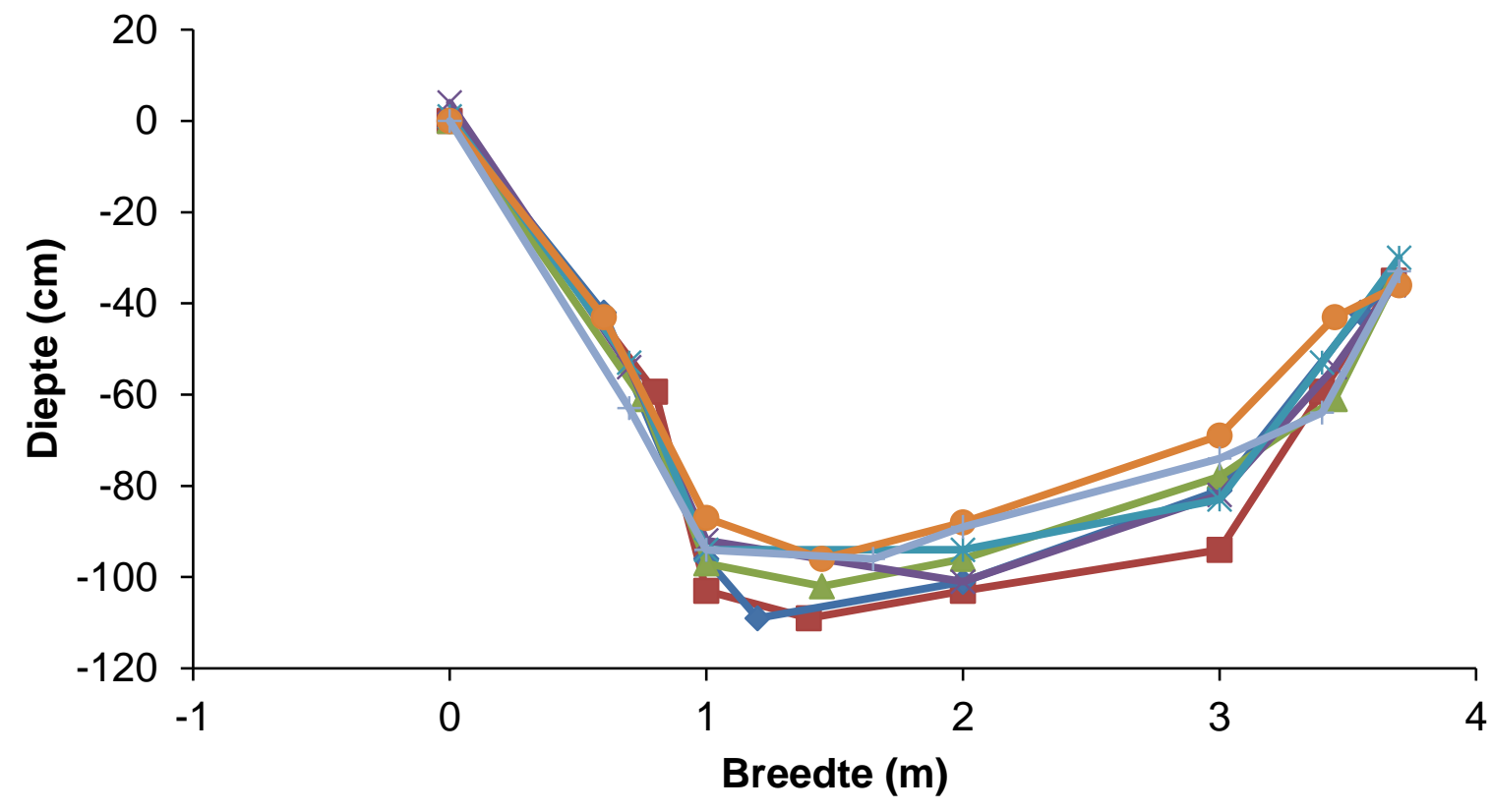

\section{Z1.8c}

$\neg$-okt-14 $\leadsto$ apr-16 $\leftarrow$ sep-16 $*$ apr-17

* sep-17-a-apr-18 + sep-18

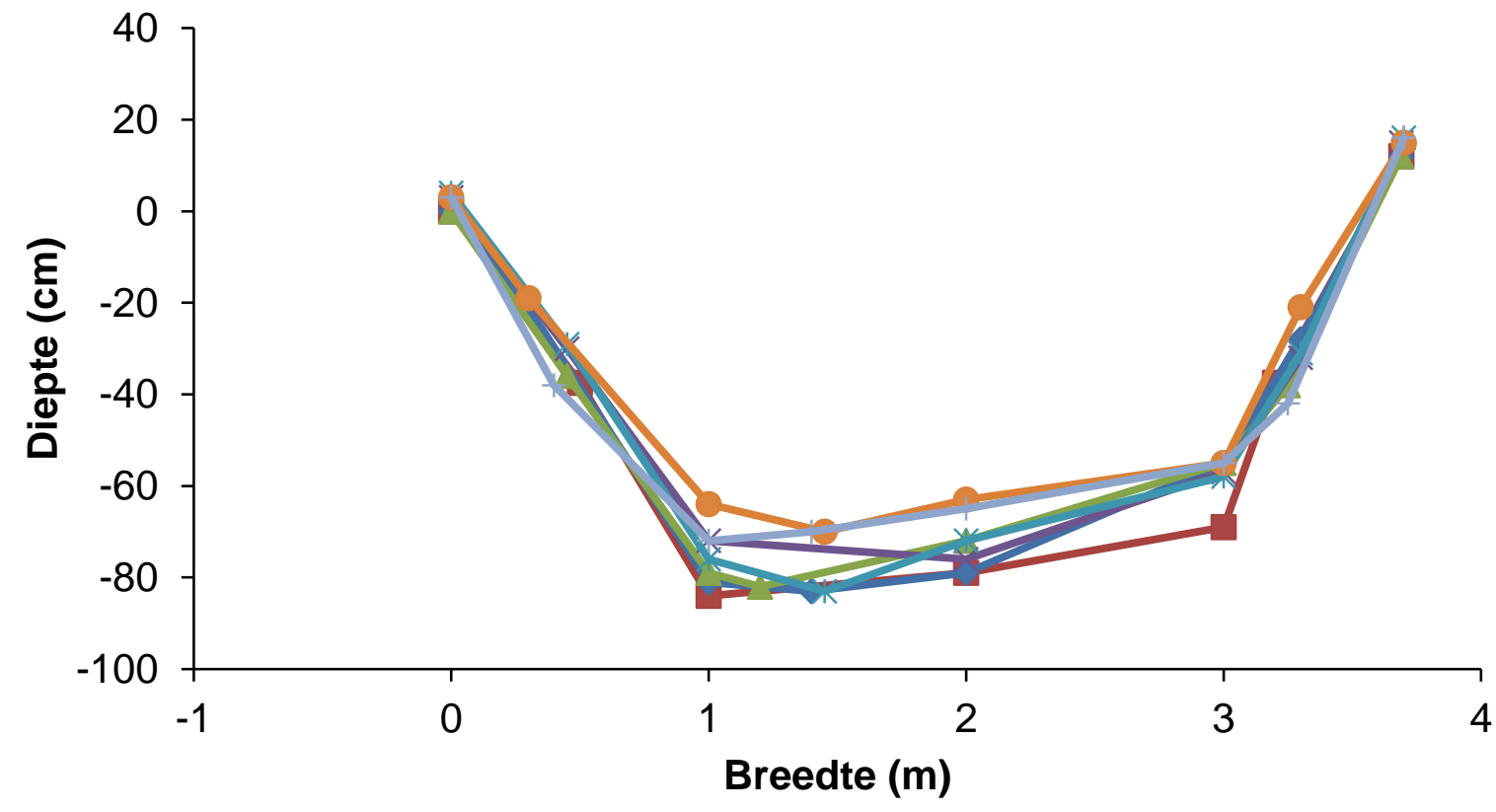




\section{Z1.9c}

$\neg$-okt-14 $\leadsto$ apr-16 $\leftarrow$ sep-16 $*$ apr-17

* sep-17-o-apr-18 + sep-18

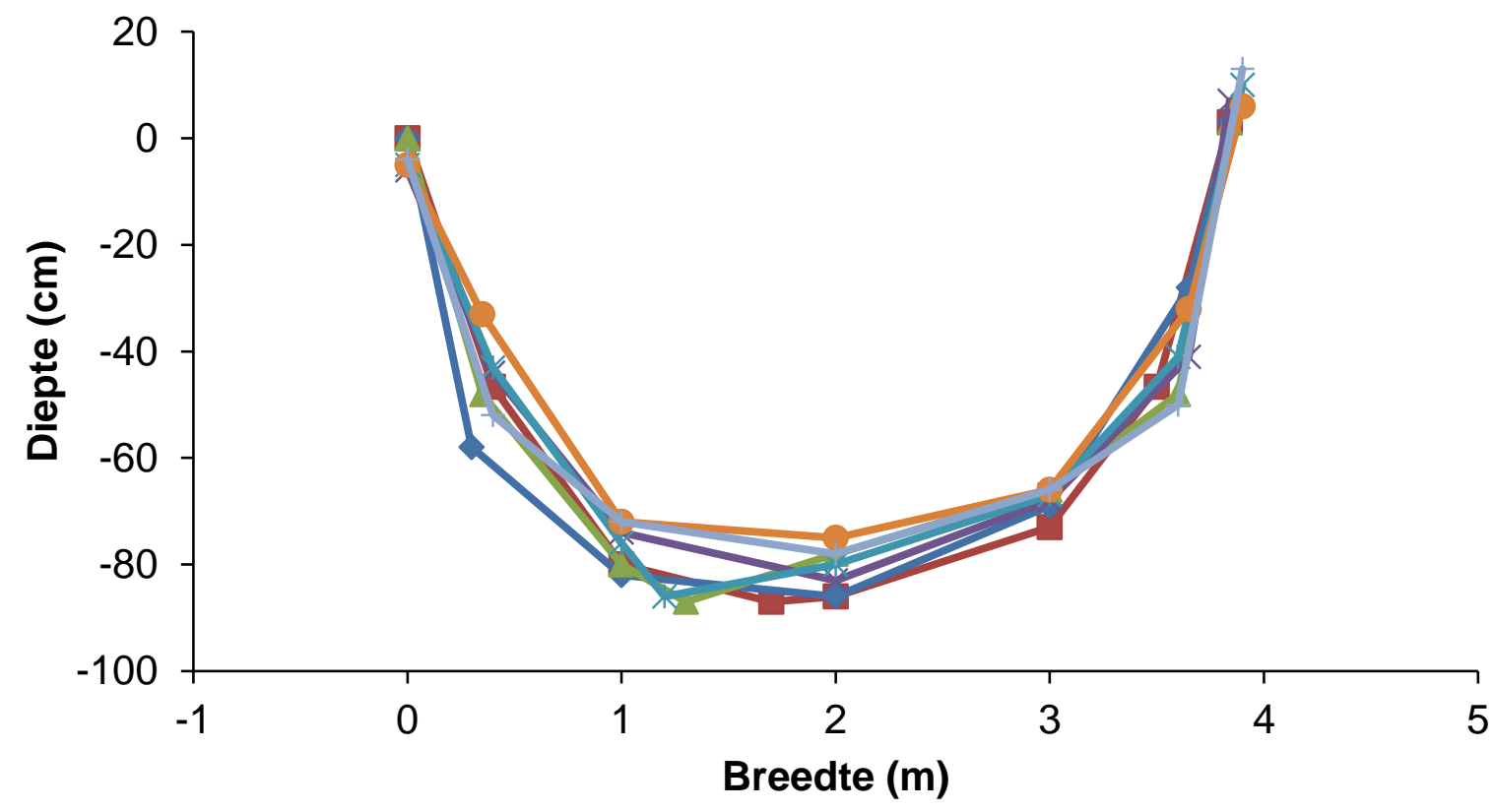




\section{Traject Z2}

Ligging transecten $(1 \mathrm{t} / \mathrm{m} 3=\mathrm{a}, 4 \mathrm{t} / \mathrm{m} 6=\mathrm{b}, 7 \mathrm{t} / \mathrm{m} 9=\mathrm{c})$ :

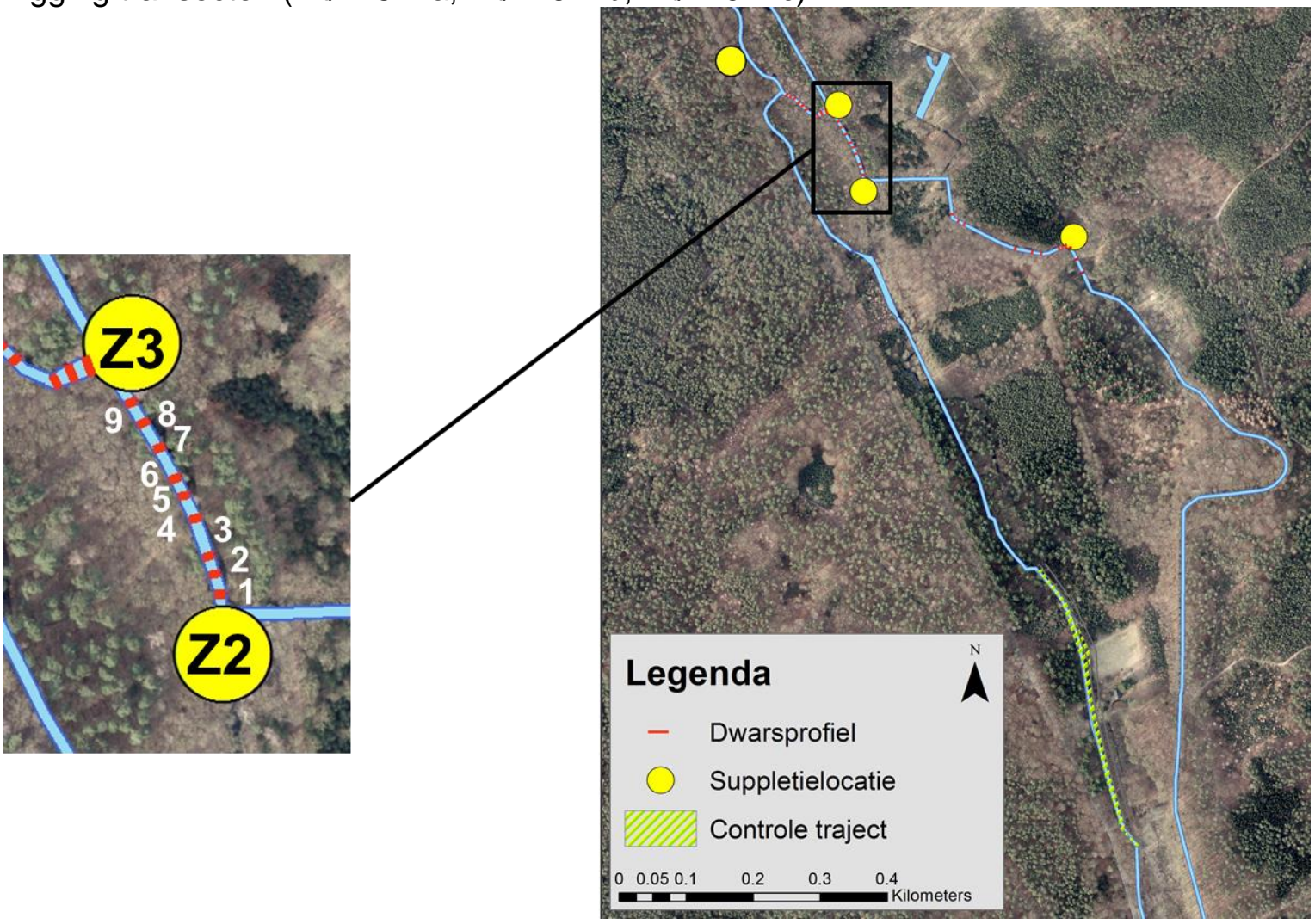




\section{Z2.1a}

- -okt-14 -apr-16 $\leftarrow$ sep-16 *apr-17

* sep-17-c-apr-18 + sep-18

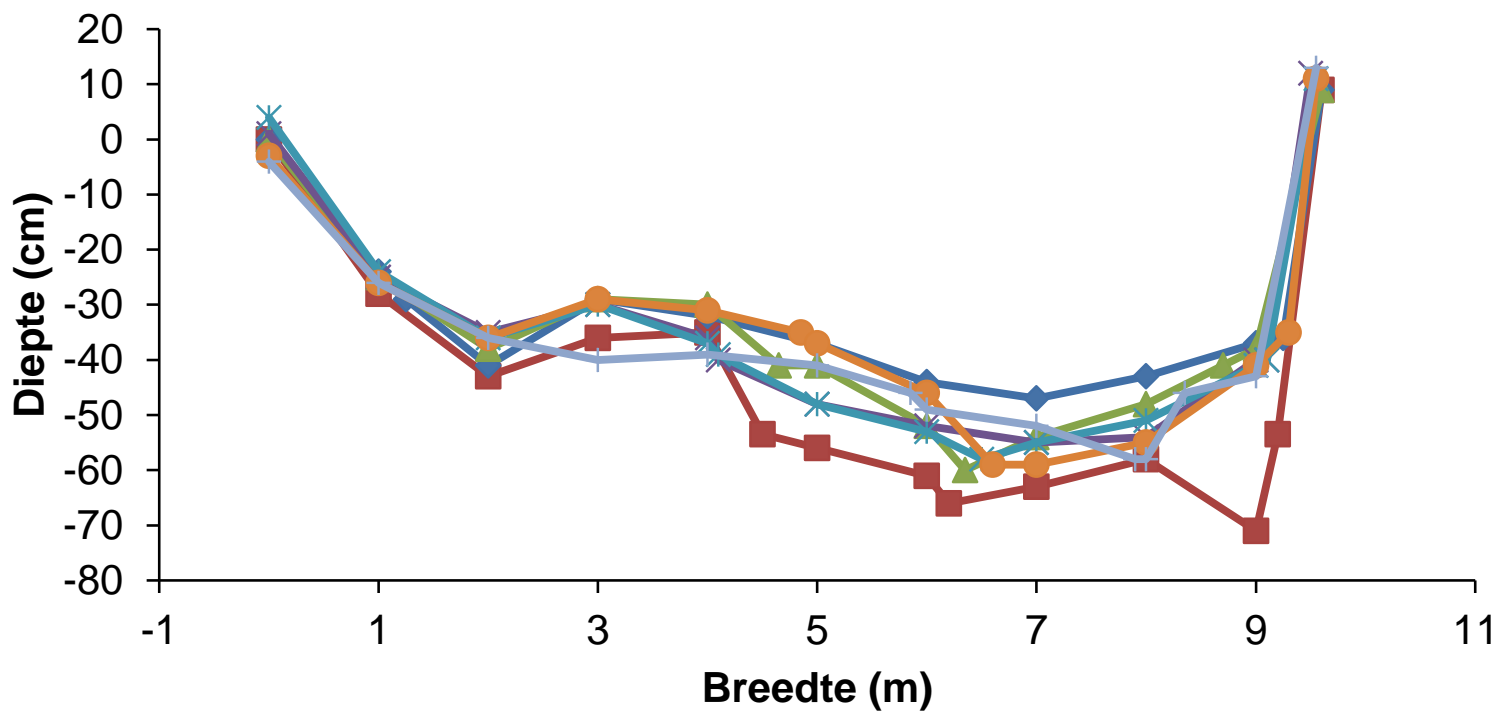

\section{Z2.2a}

- -okt-14 $\sim$ apr-16 $\leftarrow$ sep-16 *apr-17

* sep-17-apr-18 + sep-18

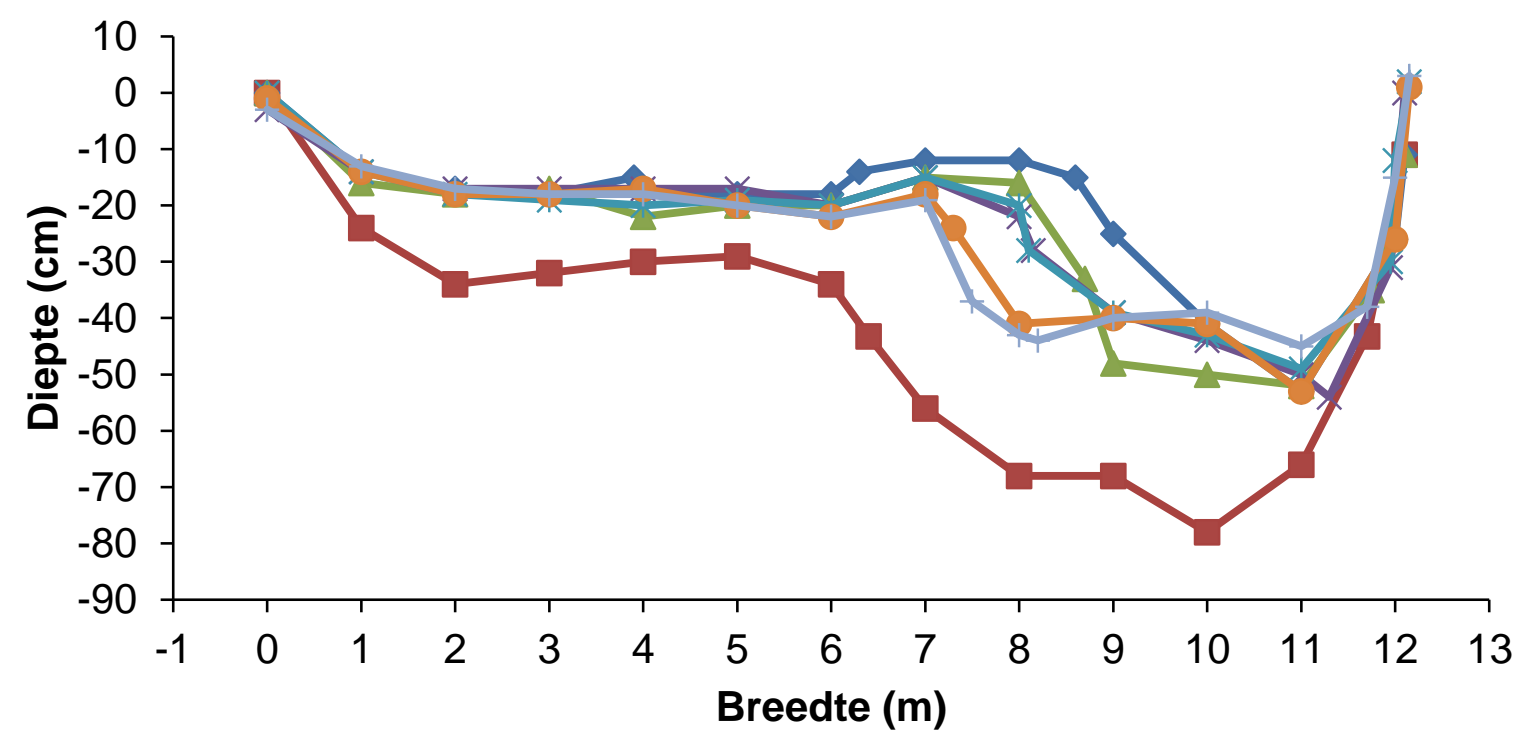




\section{Z2.3a}

$\dashv$-okt-14 -apr-16 $\leftarrow$ sep-16 *apr-17

* sep-17-a-apr-18 - sep-18

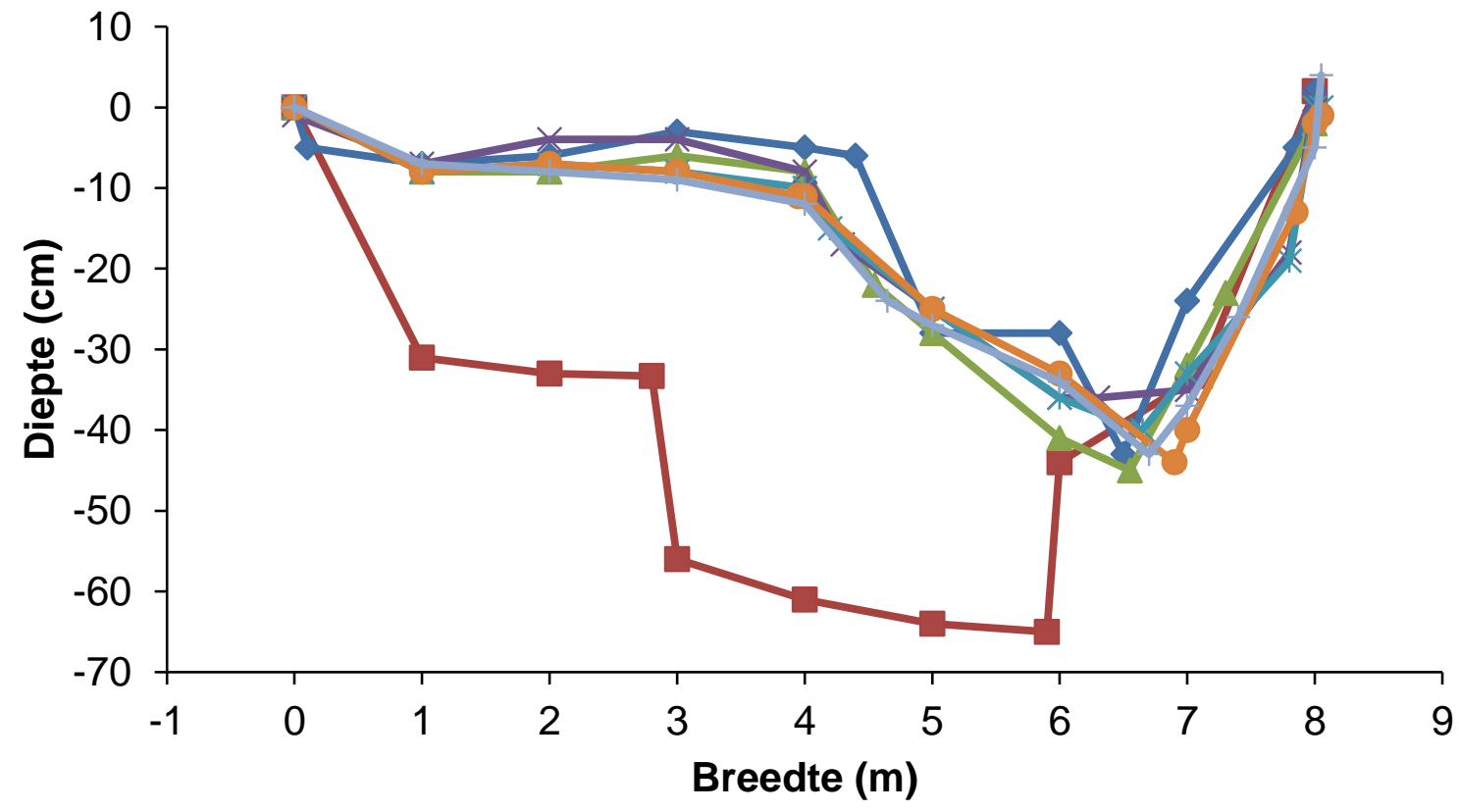

\section{Z2.4b}

$\dashv$-okt-14 -apr-16 —sep-16 *apr-17

* sep-17-o-apr-18 + sep-18

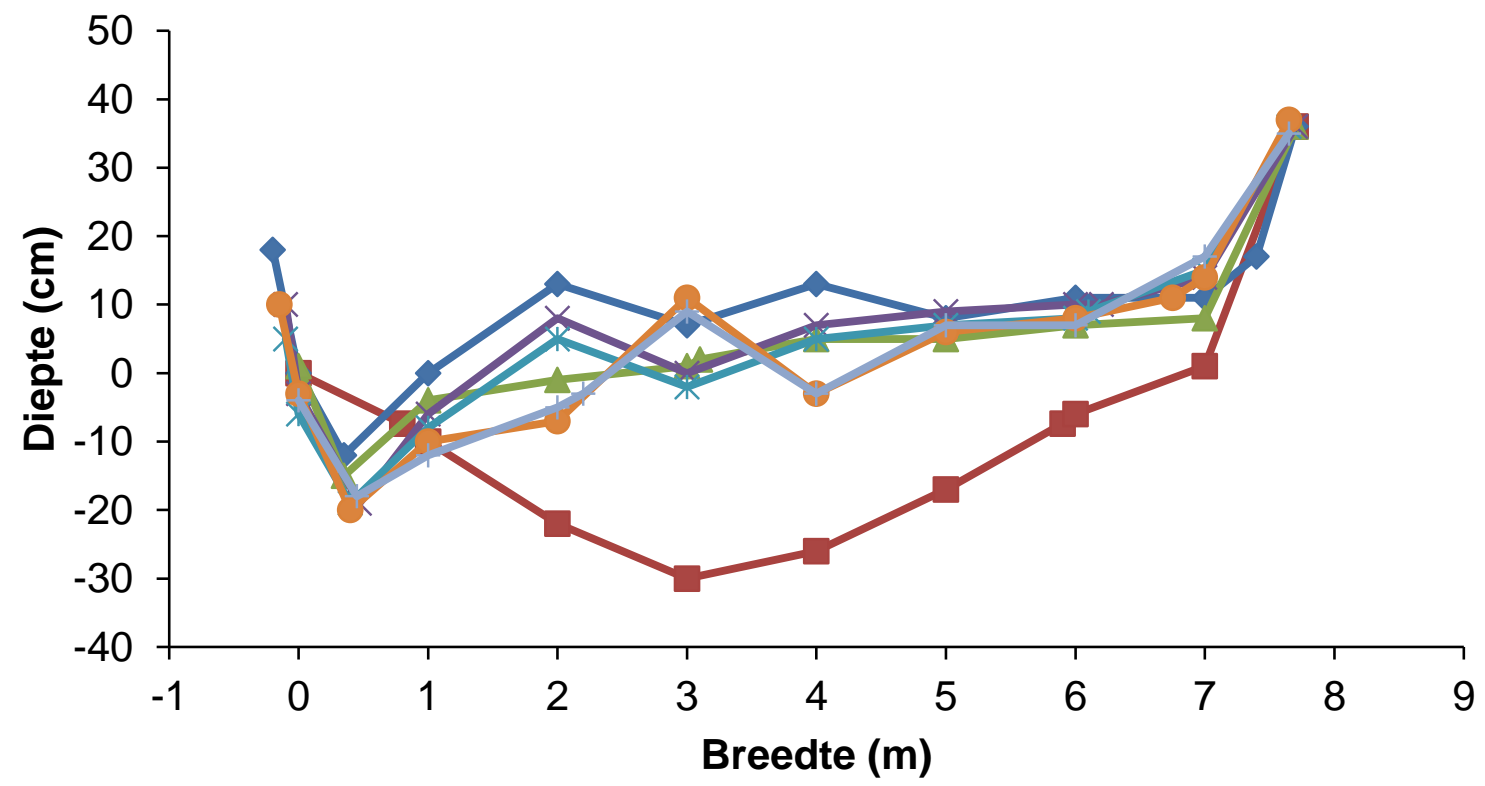




\section{$\mathrm{Z2.5b}$}

$\neg$-okt-14 $\leadsto$ apr-16 $\leftarrow$ sep-16 $*$ apr-17

*-sep-17-a-apr-18 - sep-18
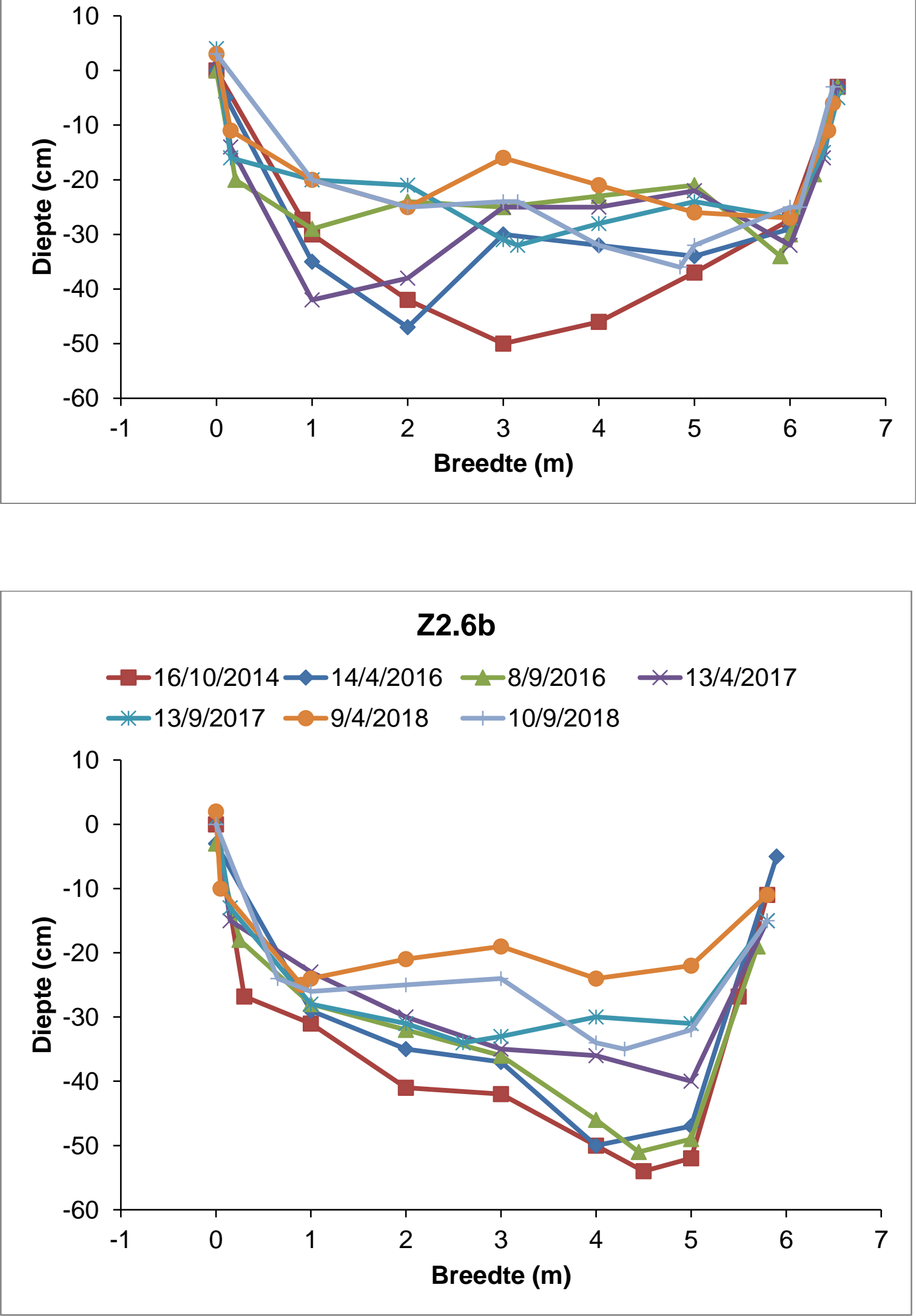

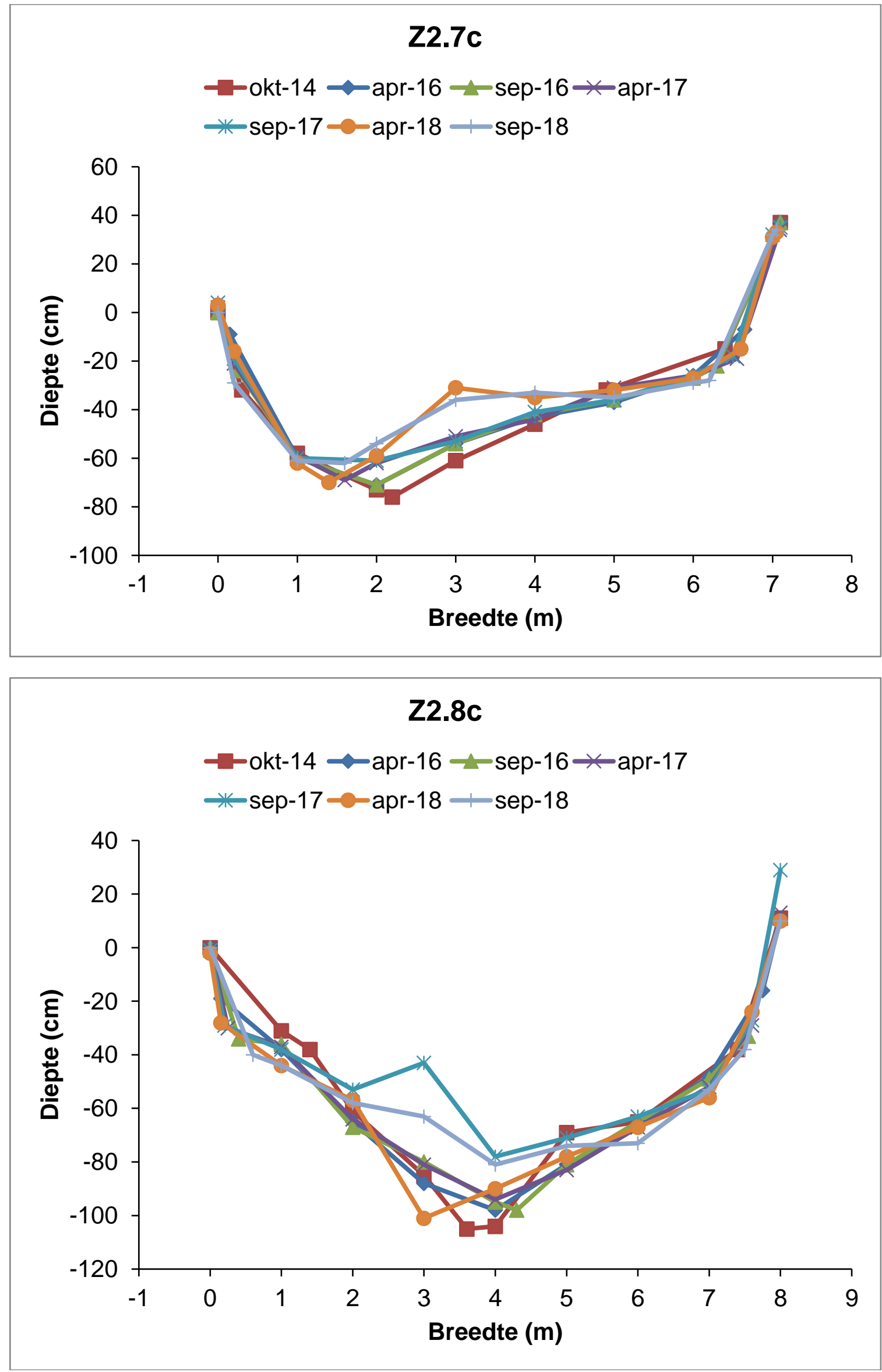

13-9-2017 boomkruin eik in transect gevallen 


\section{Z2.9c}

- -okt-14 $\leadsto$ apr-16 $\leftarrow$ sep-16 *apr-17

* sep-17-c-apr-18 + sep-18

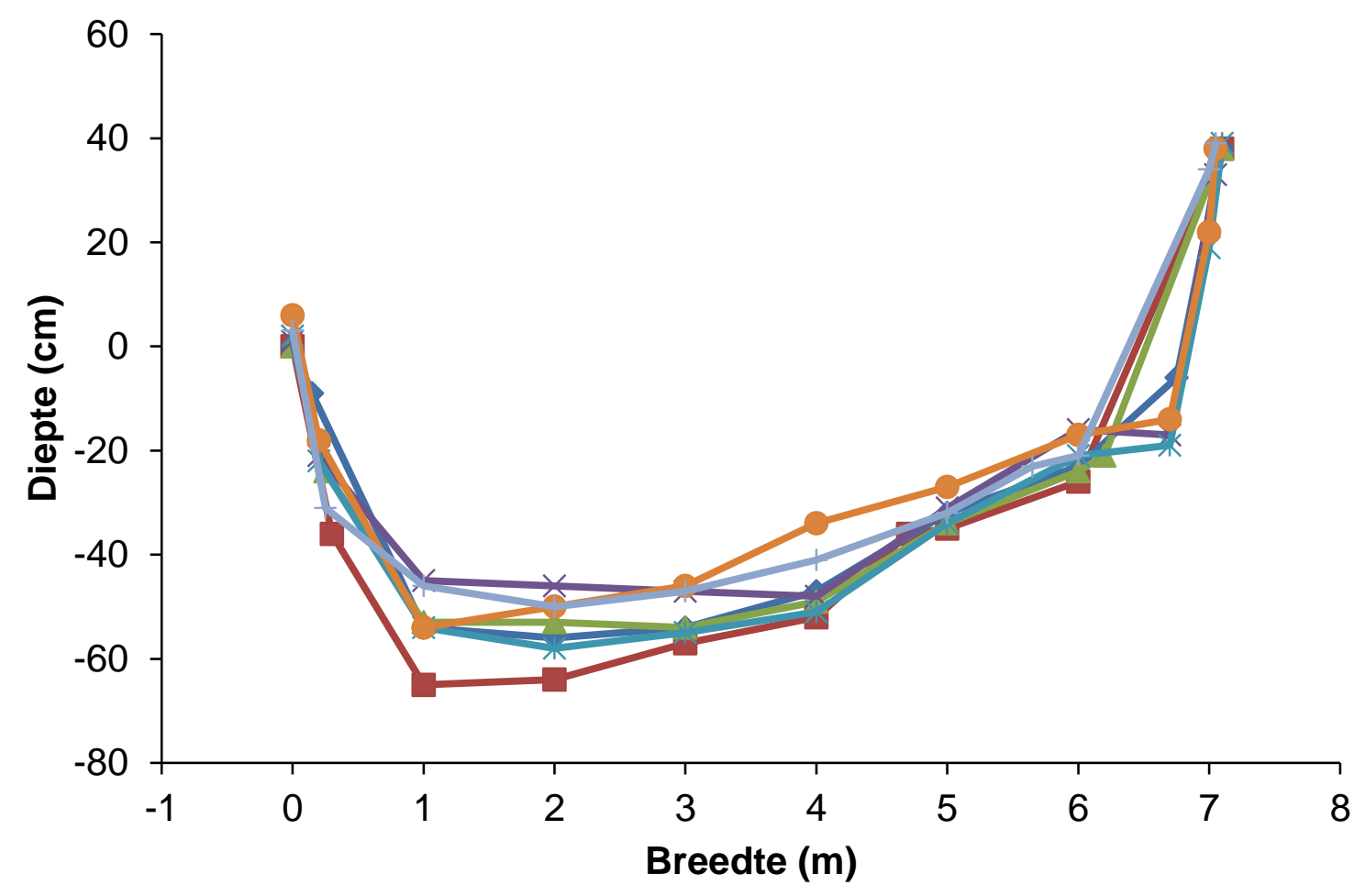




\section{Traject Z3}

Ligging transecten $(1 \mathrm{t} / \mathrm{m} 3=\mathrm{a}, 4 \mathrm{t} / \mathrm{m} 6=\mathrm{b}, 7 \mathrm{t} / \mathrm{m} 9=\mathrm{c})$ :

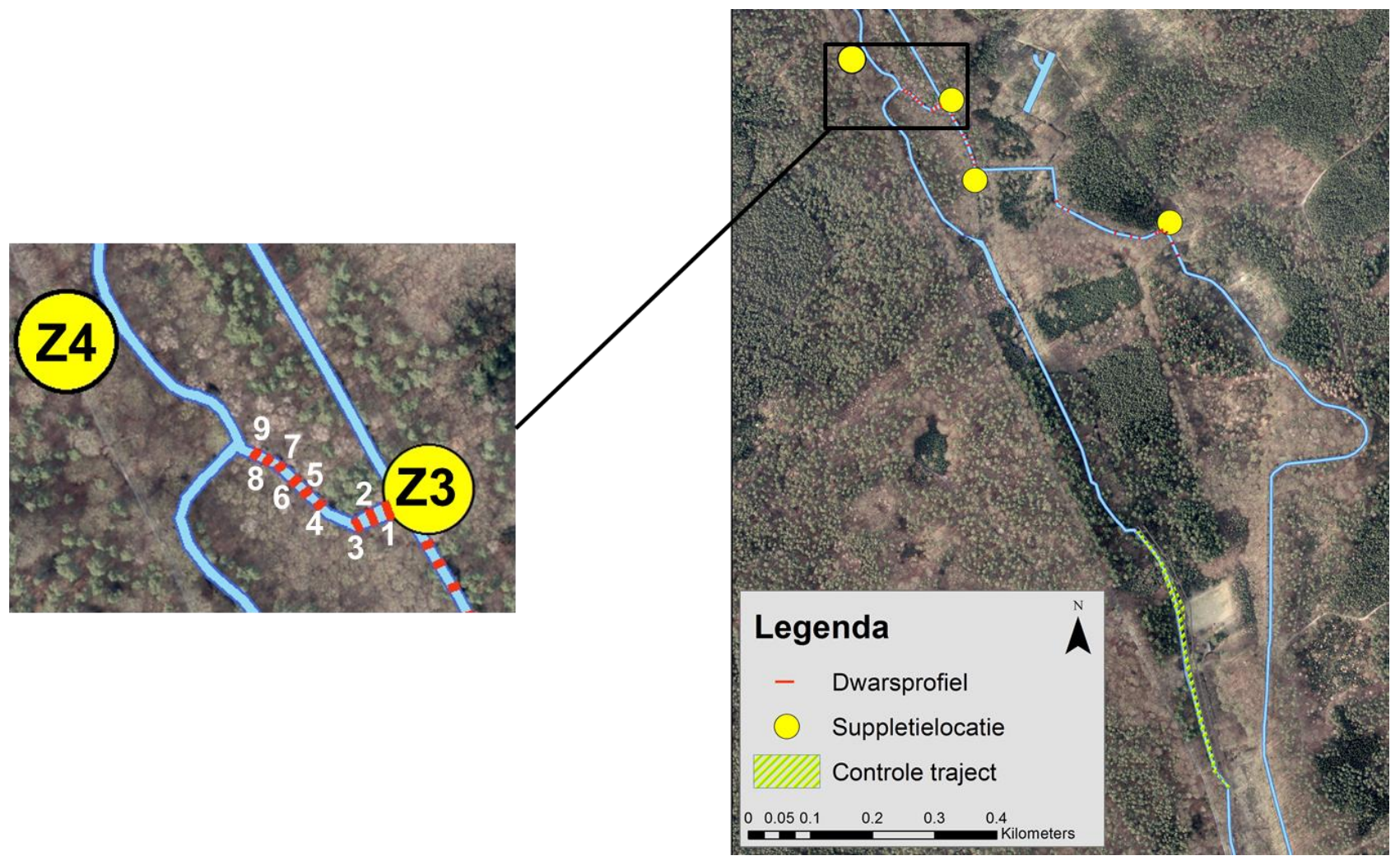




\section{Z3.1a}

$\leftarrow$-okt-14 -apr-16 $\leftarrow$ sep-16 *apr-17

* sep-17-a-apr-18 + sep-18

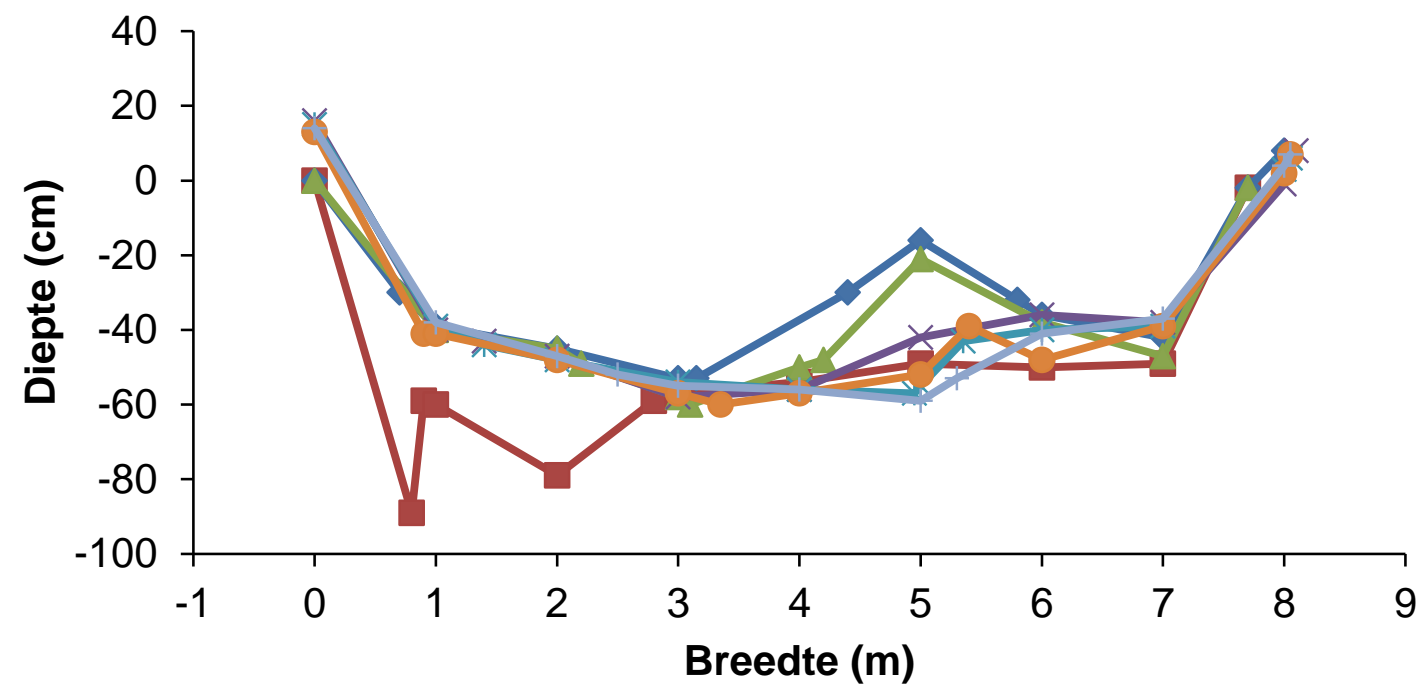

\section{$\mathrm{Z3.2a}$}

$\dashv$-okt-14 —apr-16 $\leftarrow$ sep-16 *apr-17

* sep-17-c-apr-18 + sep-18

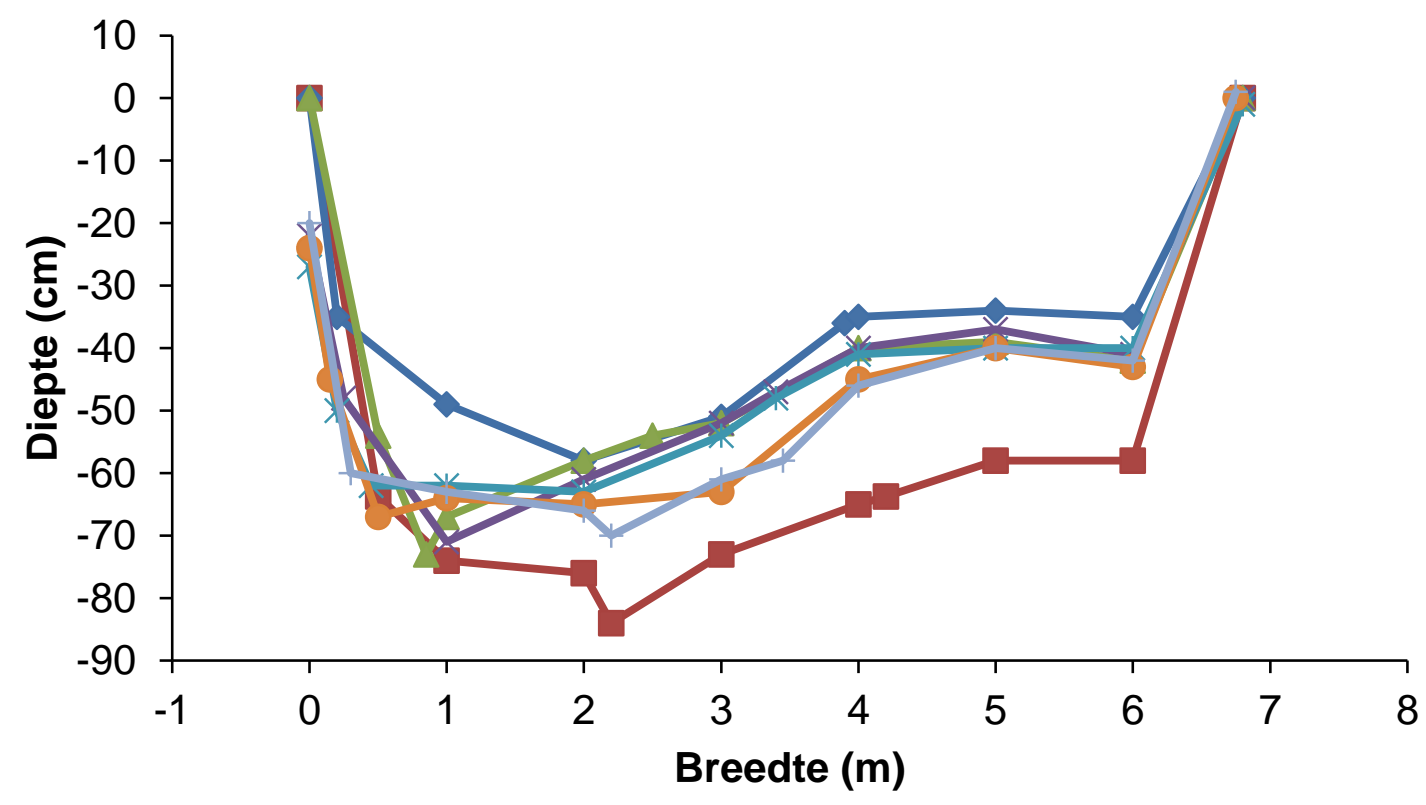




\section{Z3.3a}

$\leftarrow$-okt-14 $\sim$ apr-16 $\leftarrow$ sep-16 $*$ apr-17

*-sep-17-apr-18 - sep-18

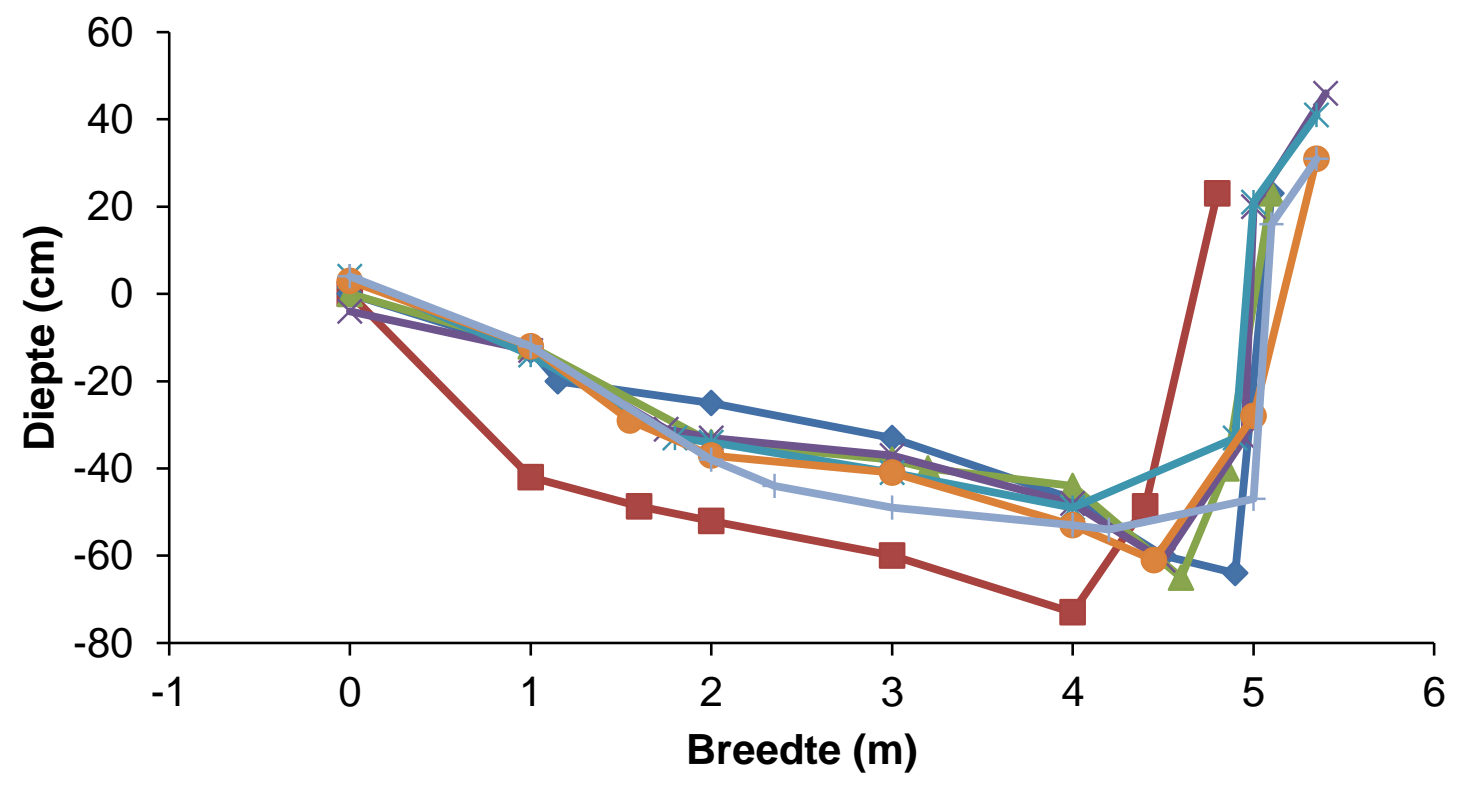

Z3.4b

$\leftarrow$-okt-14 $\leadsto$ apr-16 $\leftarrow$ sep-16 *apr-17

* sep-17 - apr-18 + sep-18

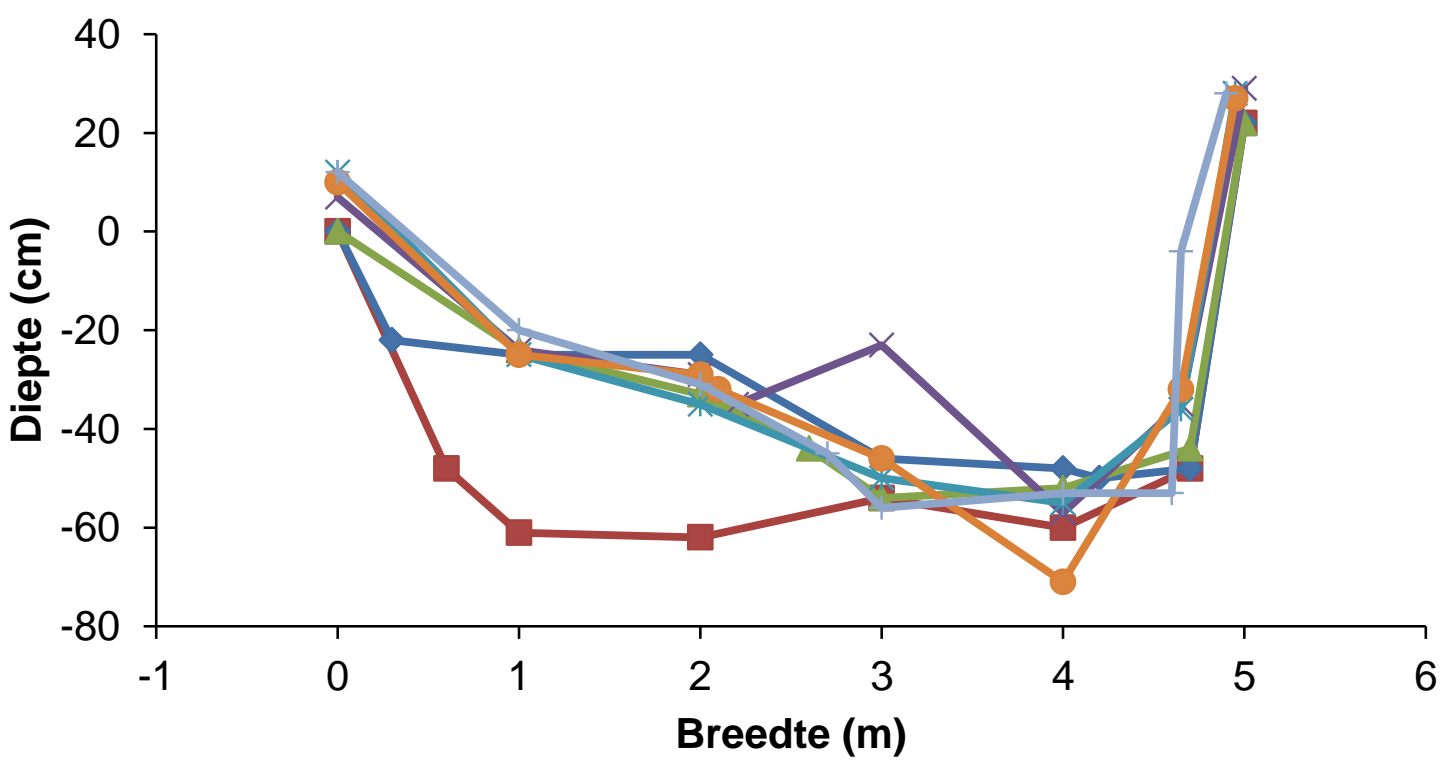



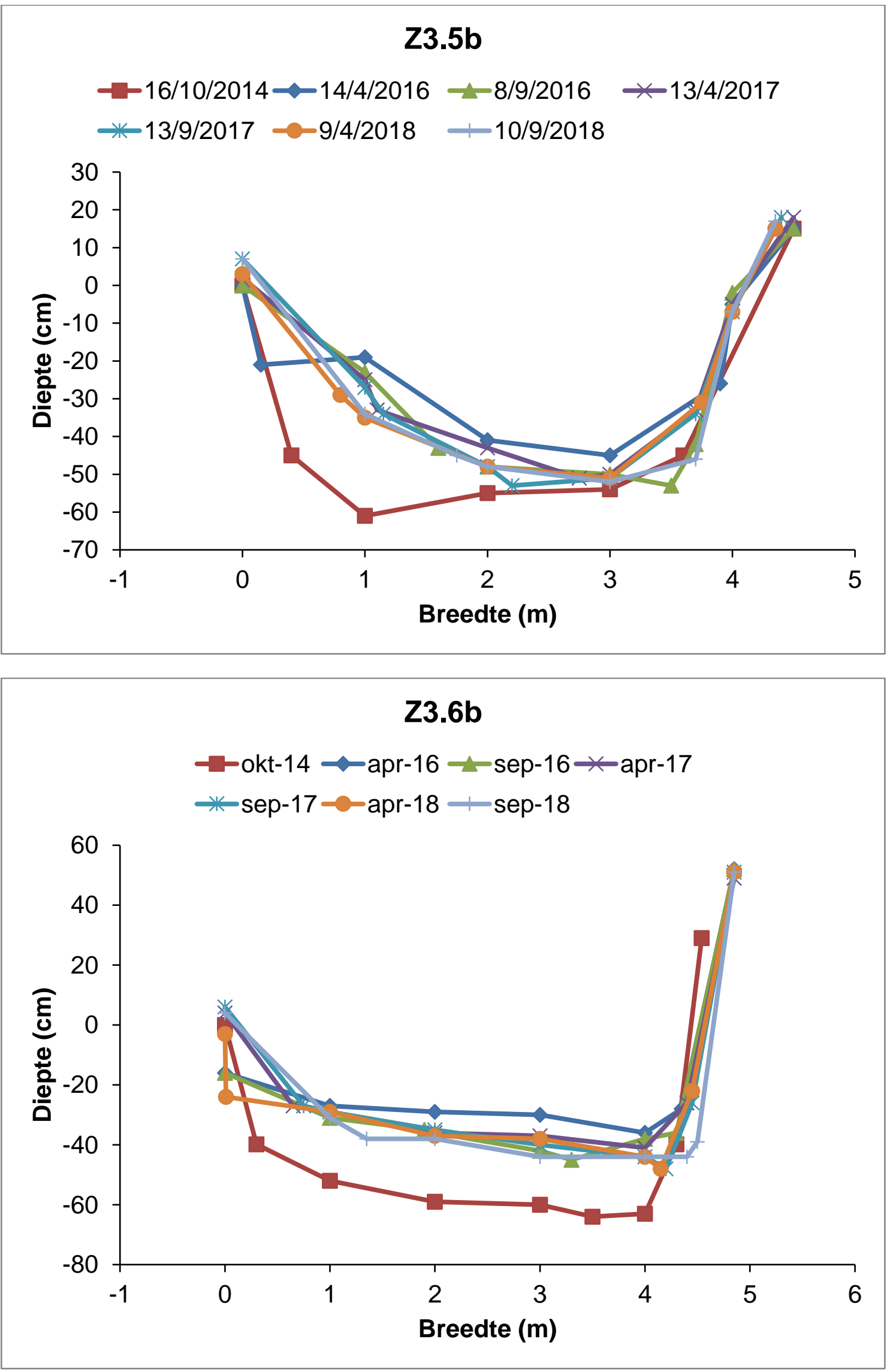


\section{Z3.7c}

$\neg$-okt-14 $\leadsto$ apr-16 $\leftarrow$ sep-16 $*$ apr-17

*-sep-17-a-apr-18 + sep-18

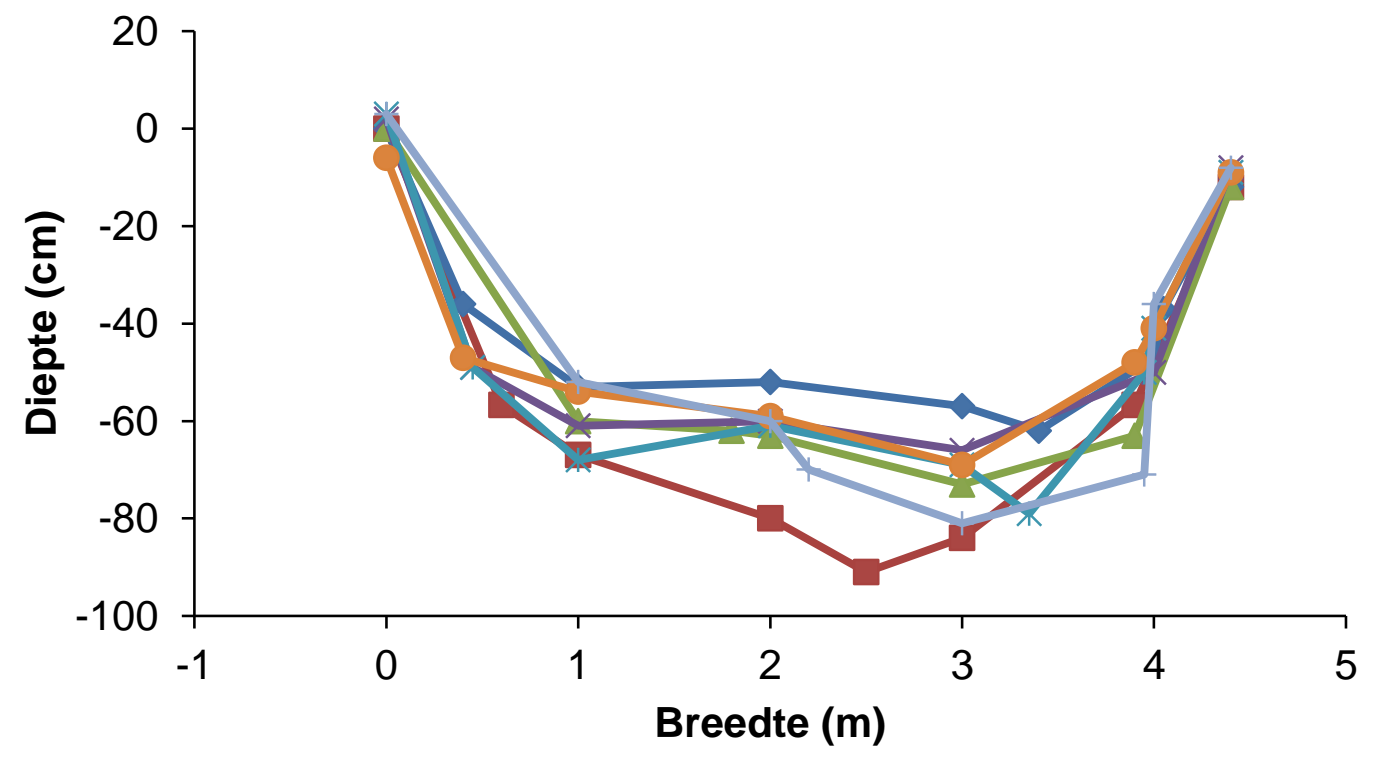

Z3.8c

$\neg$-okt-14 $\leadsto$ apr-16 $\leftarrow$ sep-16 $\leftarrow$ apr-17

* sep-17-apr-18 - sep-18

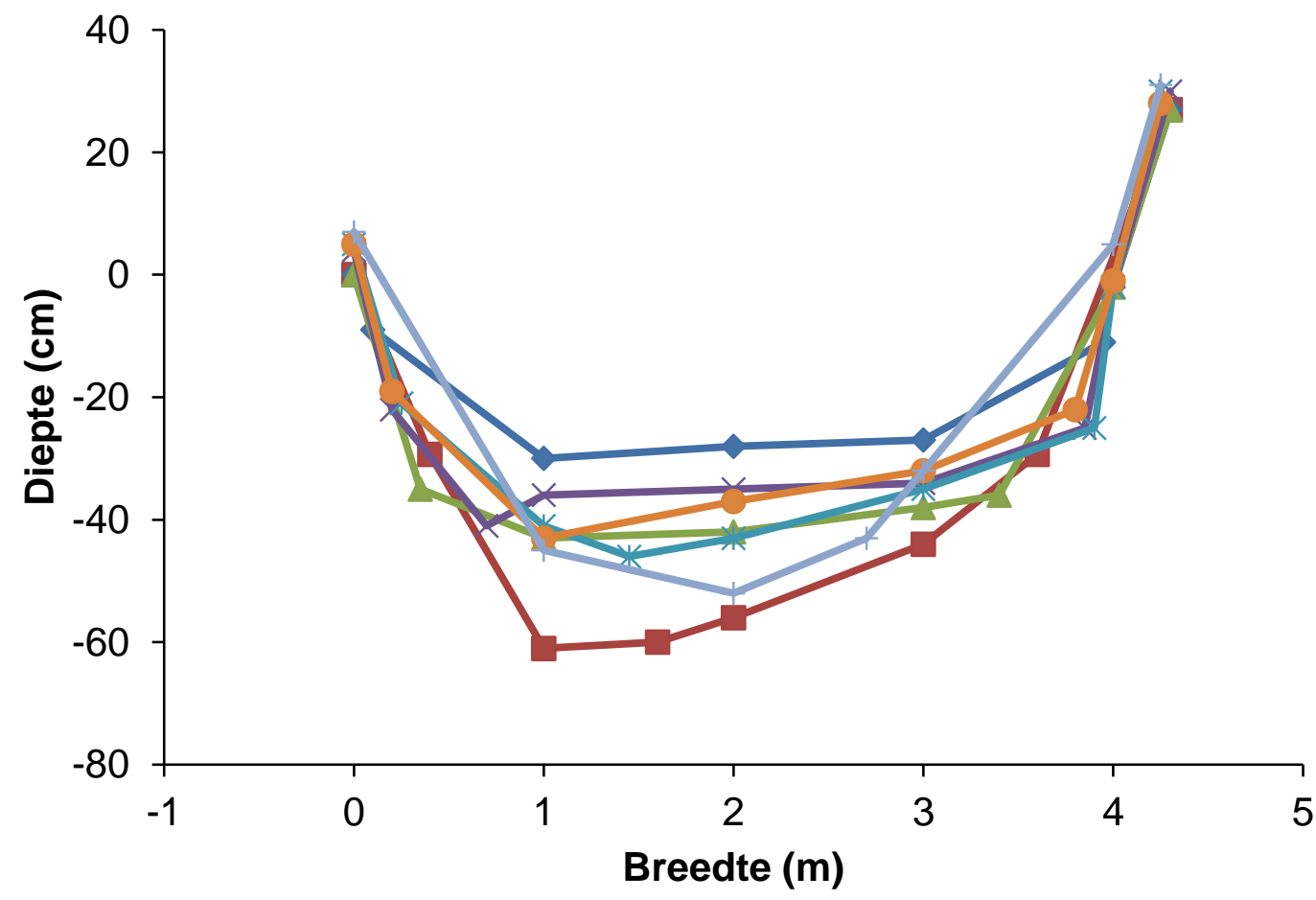




\section{Z3.9c}

$\dashv$-okt-14 $\multimap$ apr-16 $\leftarrow$ sep-16 *apr-17

*-sep-17-apr-18 + sep-18

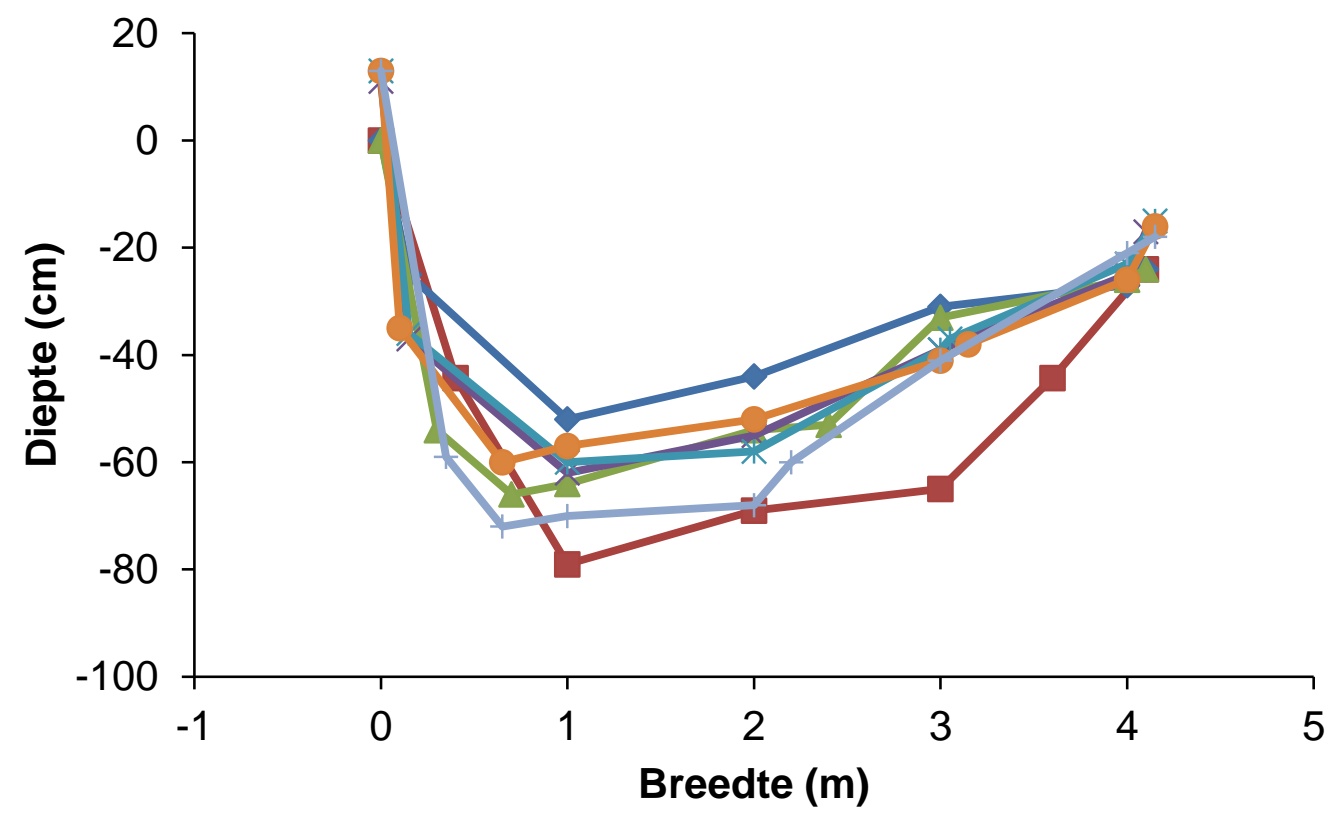




\section{Bijlage 2: dwarsprofielen van de moerasbeek}

\section{Moerasbeektraject C1}

Ligging transecten $(1 \mathrm{t} / \mathrm{m} 3=\mathrm{a}, 4 \mathrm{t} / \mathrm{m} 6=\mathrm{b}, 7 \mathrm{t} / \mathrm{m} 9=\mathrm{c})$ :

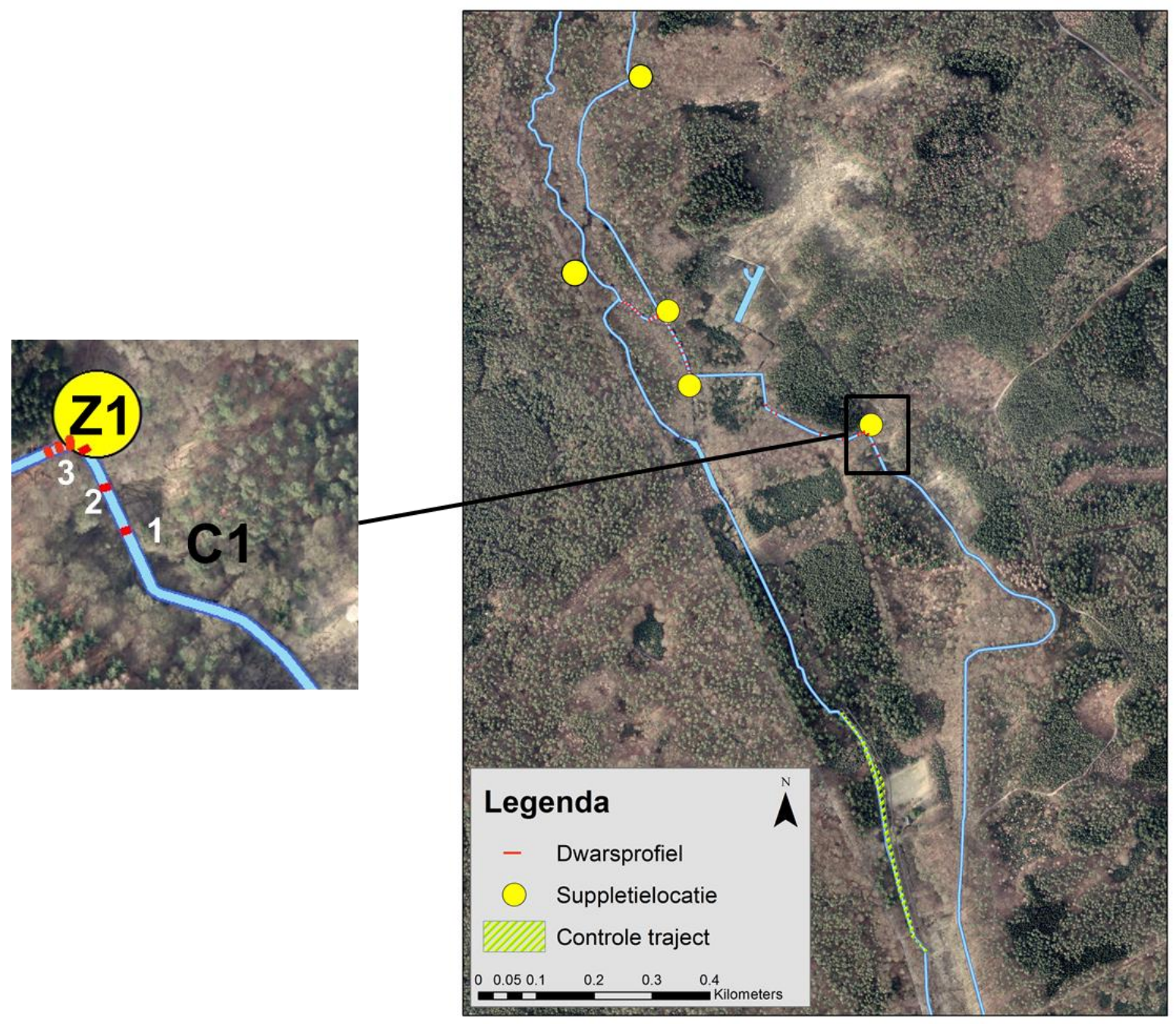



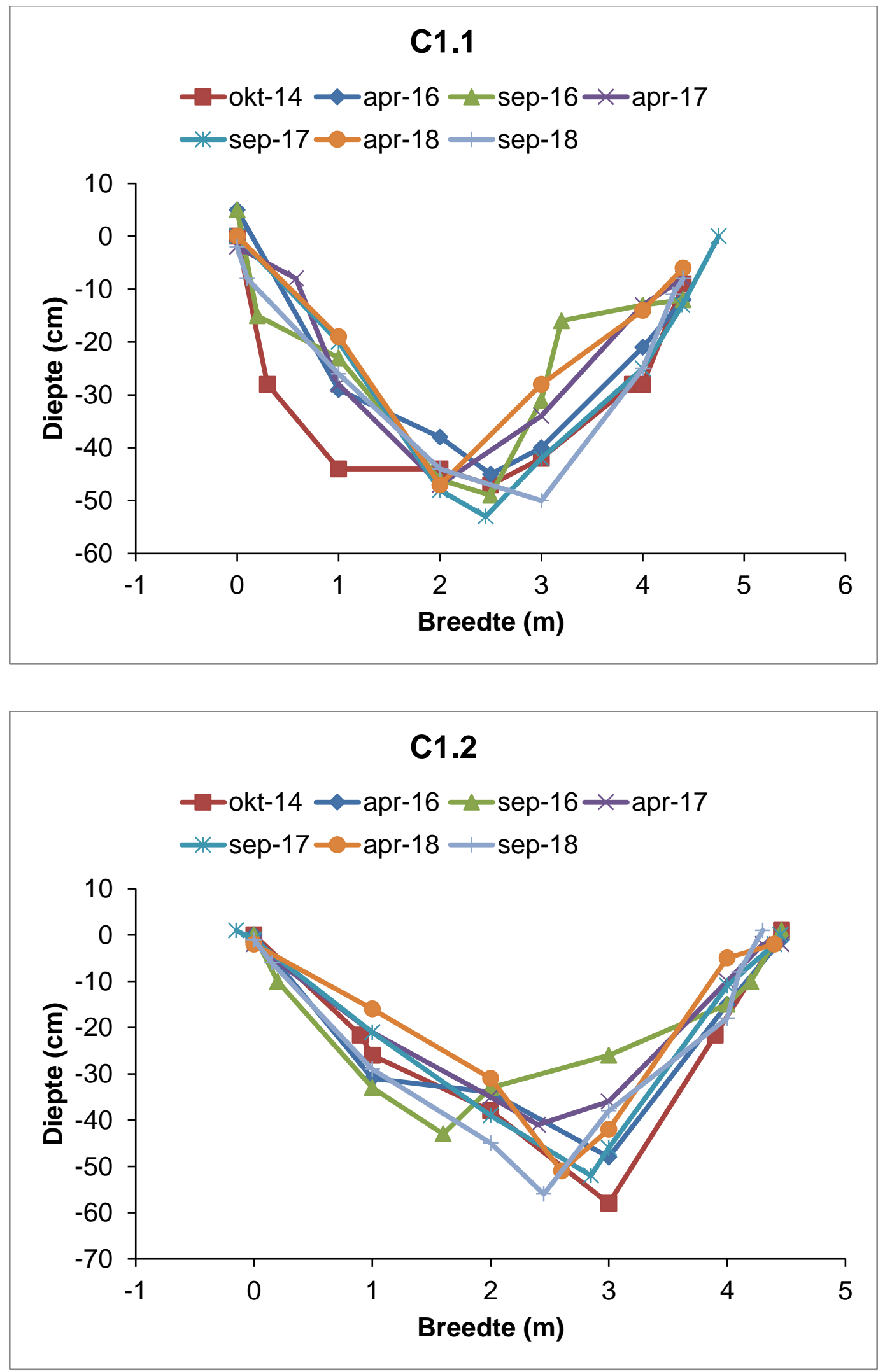


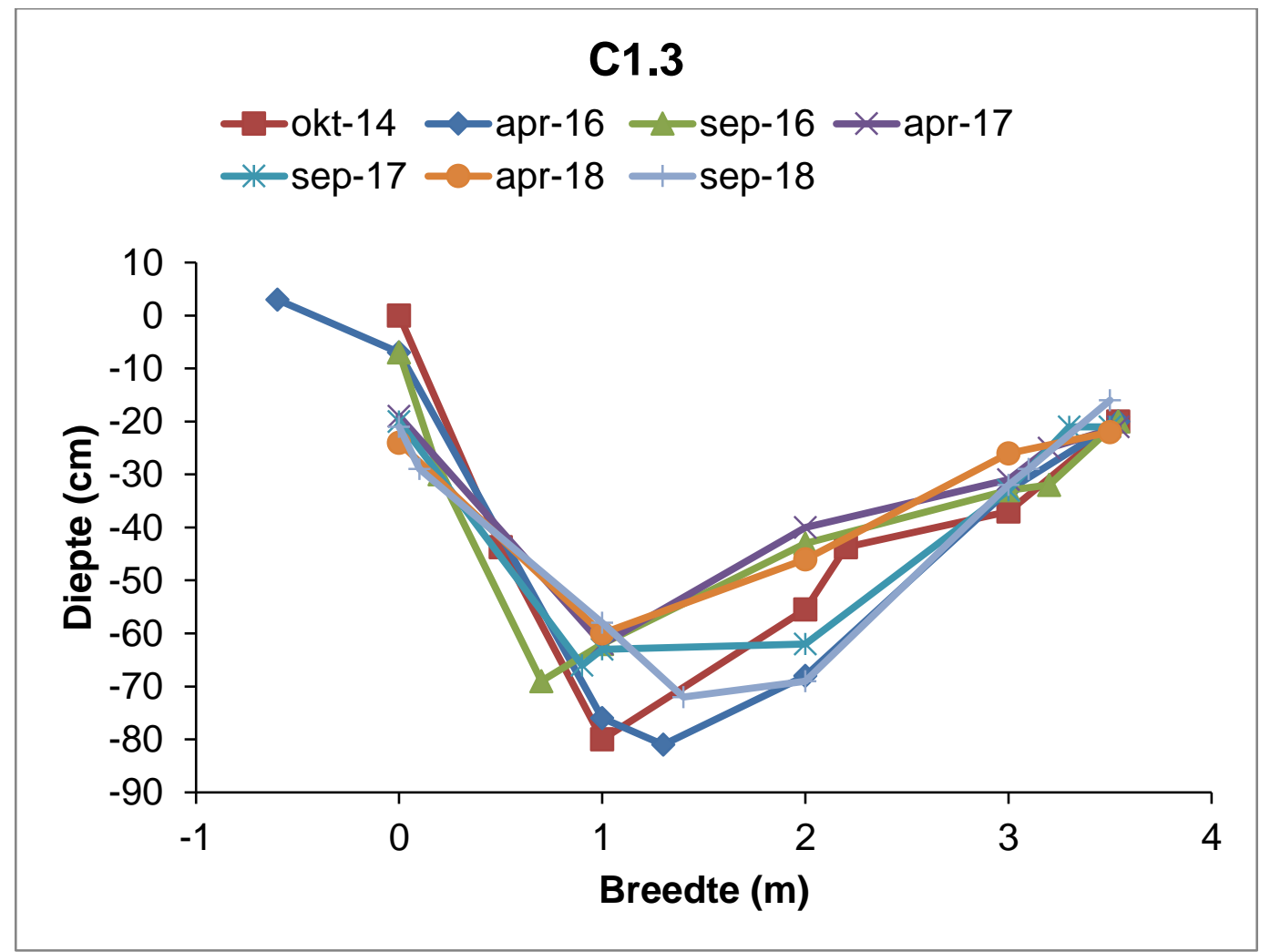




\section{Bijlage 3: Macrofaunabemonstering moerastraject bovenstrooms Z1}

Abundantie macrofauna 5-m-standaardmacrofaunanet-monsters genomen op 9 april 2018.

\begin{tabular}{|c|c|c|c|c|}
\hline Groep & Taxonnaam (TWN) & $\begin{array}{l}\text { Controle } \\
\text { Koekoek }\end{array}$ & $\begin{array}{l}\text { Z1 } \\
\text { suppletie }\end{array}$ & $\begin{array}{l}\mathrm{Z1} \\
\text { moeras }\end{array}$ \\
\hline \multirow[t]{6}{*}{ Ephemeroptera } & Ephemera danica & 29 & 5 & 1 \\
\hline & Leptophlebiidae & & 6 & \\
\hline & Leptophlebia marginata & 17 & 44 & 123 \\
\hline & Baetis & 6 & 7 & \\
\hline & Baetis vernus & 6 & 1 & \\
\hline & Cloeon dipterum & & 1 & 6 \\
\hline Plecoptera & Nemoura cinerea & 34 & 115 & 73 \\
\hline \multirow[t]{15}{*}{ Trichoptera } & Limnephilidae & & 16 & 29 \\
\hline & Glyphotaelius pellucidus & & 1 & 1 \\
\hline & Halesus radiatus & 17 & 32 & 1 \\
\hline & Limnephilus Iunatus & 2 & 10 & 25 \\
\hline & Limnephilus rhombicus & & & 1 \\
\hline & Athripsodes & 71 & & 9 \\
\hline & Athripsodes cinereus & 3 & 1 & \\
\hline & Cyrnus & 1 & & \\
\hline & Holocentropus picicornis & & & 1 \\
\hline & Hydropsyche angustipennis & & 1 & \\
\hline & Lype & & 1 & \\
\hline & Plectrocnemia & 7 & 1 & \\
\hline & Plectrocnemia conspersa & 4 & 2 & \\
\hline & Polycentropus irroratus & & & 27 \\
\hline & Polycentropodidae & & & 34 \\
\hline Megaloptera & Sialis Iutaria & 1 & & 13 \\
\hline \multirow[t]{4}{*}{ Heteroptera } & Sigara hellensii & & & 3 \\
\hline & Sigara distincta & & & 1 \\
\hline & Sigara fossarum & & & 1 \\
\hline & Sigara striata & & & 1 \\
\hline \multirow[t]{5}{*}{ Coleoptera } & Dytiscidae & & 1 & \\
\hline & Agabus sturmii & & & 1 \\
\hline & Orectochilus villosus & 17 & 3 & \\
\hline & Gyrinus substriatus & & 1 & \\
\hline & Limnius volckmari & 1 & & \\
\hline \multirow[t]{8}{*}{ Diptera } & Chironomidae & 64 & 166 & 32 \\
\hline & Ablabesmyia monilis/phatta & & & 2 \\
\hline & Apsectrotanypus trifascipennis & 7 & 12 & 131 \\
\hline & Cladotanytarsus & 9 & 97 & \\
\hline & Corynoneura & & 1 & 3 \\
\hline & Conchapelopia & 2 & 30 & 13 \\
\hline & Cricotopus sylvestris gr. & & & 1 \\
\hline & Epoicocladius ephemerae & 7 & & \\
\hline
\end{tabular}




\begin{tabular}{|c|c|c|c|c|}
\hline Groep & Taxonnaam (TWN) & \begin{tabular}{|l|} 
Controle \\
Koekoek
\end{tabular} & \begin{tabular}{|l|} 
Z1 \\
suppletie
\end{tabular} & $\begin{array}{l}\mathrm{Z1} \\
\text { moeras }\end{array}$ \\
\hline & Heterotrissocladius marcidus & 2 & 1 & 4 \\
\hline & Macropelopia nebulosa & & & 1 \\
\hline & Micropsectra & 2 & 28 & 7 \\
\hline & Natarsia & & & 2 \\
\hline & Paracladopelma laminatum agg. & & 8 & 2 \\
\hline & Paracladopelma nigritulum & 6 & & \\
\hline & Paracladopelma & 6 & 9 & 2 \\
\hline & Paratendipes albimanus & & 1 & 11 \\
\hline & Paratrichocladius & 1 & & \\
\hline & Phaenopsectra & 1 & 1 & 1 \\
\hline & Polypedilum albicorne & 3 & 5 & \\
\hline & Polypedilum & & 1 & \\
\hline & Procladius & 1 & & 19 \\
\hline & Rheocricotopus & 1 & 9 & \\
\hline & Rheocricotopus fuscipes & & & 9 \\
\hline & Stempellinella brevis & 21 & 7 & 59 \\
\hline & Stictochironomus & & 21 & \\
\hline & Thienemanniella majuscula & & & 1 \\
\hline & Thienemanniella & & 1 & \\
\hline & Wiedemannia & & & 1 \\
\hline & Zavrelimyia & 1 & 6 & 36 \\
\hline & Simuliidae & 2 & 11 & 1 \\
\hline & Simulium cryophilum & & 41 & 5 \\
\hline & Simulium vernum & & 9 & 1 \\
\hline & Ceratopogonidae & 7 & 22 & 28 \\
\hline & Tabanidae & 3 & & \\
\hline & Eloeophila & 4 & 2 & \\
\hline & Dicranota & 5 & 1 & \\
\hline & Ephydridae & & & 1 \\
\hline & Pilaria & & & 5 \\
\hline & Chelifera & & 1 & \\
\hline & Nephrotoma & & 1 & \\
\hline \multirow[t]{5}{*}{ Gastropoda } & Pisidium & 5 & & 61 \\
\hline & Pisidium subtruncatum & 57 & & 32 \\
\hline & Acroloxus lacustris & & & 1 \\
\hline & Gyraulus & & 1 & \\
\hline & Radix & & & 1 \\
\hline \multirow[t]{2}{*}{ Gammaridae } & Gammarus pulex & 424 & 445 & 52 \\
\hline & Gammarus & & & 8 \\
\hline \multirow[t]{2}{*}{ Asellidae } & Asellus aquaticus & 13 & 14 & 3 \\
\hline & Proasellus coxalis & & 3 & \\
\hline \multirow[t]{2}{*}{ Hirudinae } & Erpobdella octoculata & 5 & & 7 \\
\hline & Glossiphonia complanata & 5 & 6 & 4 \\
\hline \multirow[t]{2}{*}{ Oligochaeta } & Oligochaeta & & & 1 \\
\hline & Tubificidae & 22 & 1 & 35 \\
\hline
\end{tabular}




\begin{tabular}{|l|l|l|l|l|}
\hline Groep & Taxonnaam (TWN) & $\begin{array}{l}\text { Controle } \\
\text { Koekoek }\end{array}$ & $\begin{array}{l}\text { Z1 } \\
\text { suppletie }\end{array}$ & $\begin{array}{l}\text { Z1 } \\
\text { moeras }\end{array}$ \\
\hline & Naididae & & 3 & \\
\hline & Lumbriculus variegatus & 3 & & 4 \\
\hline & Limnodrilus hoffmeisteri & 2 & & \\
\hline & Ophidonais serpentina & & 5 & 5 \\
\hline & Psammoryctides barbatus & 4 & & \\
\hline & Slavina appendiculata & & & 4 \\
\hline & Nais & & 7 & \\
\hline Hydracarina & Nais barbata & & & 1 \\
\hline & Arrenurus buccinator & & & 1 \\
\hline & Hygrobates arenarius & 42 & 16 & 12 \\
\hline & Hygrobates longipalpis & & & 1 \\
\hline & Hygrobates nigromaculatus [2] & 6 & 1 & \\
\hline & Mideopsis crassipes & & 1 & \\
\hline & Sperchon setiger & 4 & & \\
\hline Planaria & Sperchon & 1 & & \\
\hline & Polycelis tenuis & 2 & & \\
\hline & & &
\end{tabular}

